\title{
Identification of GSK3186899/DDD853651 as a Preclinical Development Candidate for the Treatment of Visceral Leishmaniasis
}

Michael G. Thomas, ${ }^{\dagger}$ Manu De Rycker, ${ }^{\dagger}$ Myriam Ajakane, ${ }^{\ddagger}$ Sébastian Albrecht, Ana Isabel Álvarez-Pedraglio, ${ }^{\S}$ Markus Boesche, ${ }^{\ddagger}$ Stephen Brand, ${ }^{\dagger}$ Lorna Campbell, ${ }^{\dagger}$ Juan Cantizani-Perez, ${ }^{\S}$ Laura A.T. Cleghorn, ${ }^{\dagger}$ Royston C.B. Copley, ${ }^{\|}$Sabrinia D. Crouch, ${ }^{\S}$ Alain Daugan, ${ }^{\perp}$ Gerard Drewes, ${ }^{\ddagger}$ Santiago Ferrer, ${ }^{\S}$ Sonja Ghidelli-Disse, ${ }^{\ddagger}$ Silvia Gonzalez, ${ }^{\S}$ Stephanie L. Gresham," Alan P. Hill," Sean J. Hindley," Rhiannon M. Lowe, "Claire J. MacKenzie, ${ }^{\dagger}$ Lorna MacLean, $^{\dagger}$ Sujatha Manthri, ${ }^{\dagger}$ Franck Martin, ${ }^{\perp}$ Juan Miguel-Siles, ${ }^{\S}$ Van Loc Nguyen, ${ }^{\perp}$ Suzanne Norval, ${ }^{\dagger}$ Maria Osuna-Cabello, ${ }^{\dagger}$ Andrew Woodland, ${ }^{\dagger}$ Stephen Patterson, ${ }^{\dagger}$ Imanol Pena, ${ }^{\S}$ Maria Teresa Quesada-Campos, ${ }^{\S}$ Iain H. Reid," Charlotte Revill, ${ }^{\dagger}$ Jennifer Riley, ${ }^{\dagger}$ Jose Ramon Ruiz-Gomez, ${ }^{\S}$ Yoko Shishikura, ${ }^{\dagger}$ Frederick R.C. Simeons, ${ }^{\dagger}$ Alasdair Smith, ${ }^{\dagger}$ Victoria C. Smith, ${ }^{\dagger}$ Daniel Spinks, ${ }^{\dagger}$ Laste Stojanovski, ${ }^{\dagger}$ John Thomas, ${ }^{\dagger}$ Stephen Thompson, ${ }^{\dagger}$ Tim Underwood, ${ }^{\|}$David W. Gray, ${ }^{\dagger}$ Jose M. Fiandor, ${ }^{\S}$ Ian H. Gilbert, ${ }^{\dagger}$ (ㅇ Paul G. Wyatt, ${ }^{*}{ }^{\dagger}$ Kevin D. Read, ${ }^{* \dagger}{ }^{\dagger}$ and Timothy J. Miles ${ }^{*}, \S$

${ }^{\dagger}$ Drug Discovery Unit, Wellcome Centre for Anti-Infectives Research, Division of Biological Chemistry and Drug Discovery, School of Life Sciences, University of Dundee, Dundee DD1 5EH, U.K.

${ }^{\ddagger}$ Cellzome GmbH, A GlaxoSmithKline Company, Meyerhofstrasse 1, 69117 Heidelberg, Germany

${ }^{\S}$ Global Health R\&D, GlaxoSmithKline, Calle Severo Ochoa, 2, 28760 Tres Cantos, Madrid Spain

"Platform Technology \& Science, GlaxoSmithKline Medicines Research Centre, Gunnels Wood Road, Stevenage, Hertfordshire SG1 2NY, U.K.

${ }^{\perp}$ Centre de Recherche, GlaxoSmithKline, Les Ulis, 25,27 Avenue du Québec, 91140 Villebon sur Yvette France

"Platform Technology \& Science, GlaxoSmithKline, David Jack Centre for R\&D, Park Road, Ware, Hertfordshire SG12 0DP, U.K.

Supporting Information

ABSTRACT: The leishmaniases are diseases that affect millions of people across the world, in particular visceral leishmaniasis (VL) which is fatal unless treated. Current standard of care for VL suffers from multiple issues and there is a limited pipeline of new candidate drugs. As such, there is a clear unmet medical need to identify new treatments. This paper describes the optimization of a phenotypic hit against Leishmania donovani, the major causative organism of VL. The key challenges were to balance solubility and metabolic stability while maintaining potency. Herein, strategies to address these shortcomings and enhance efficacy are discussed, culminating in the discovery of preclinical development candidate GSK3186899/DDD853651 (1) for VL.

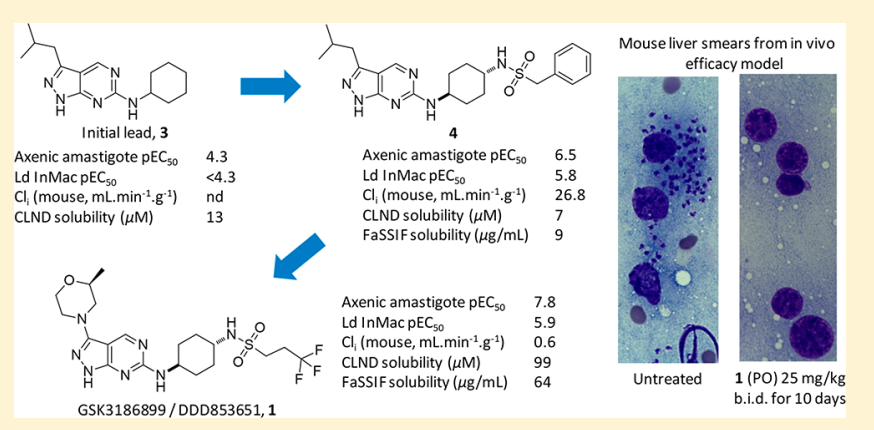

also the communities in which they live, contributing to a perpetual cycle of poverty. The leishmaniases affect people across Africa, the Middle East, South America, and Asia. There are about 20 species or subspecies of Leishmania which cause human disease. Visceral leishmaniasis (VL, also known as kala azar), caused by Leishmania donovani and Leishmania infantum, is typically fatal without treatment with 200000-400000 new

Received: August 2, 2018

Published: December 20, 2018 

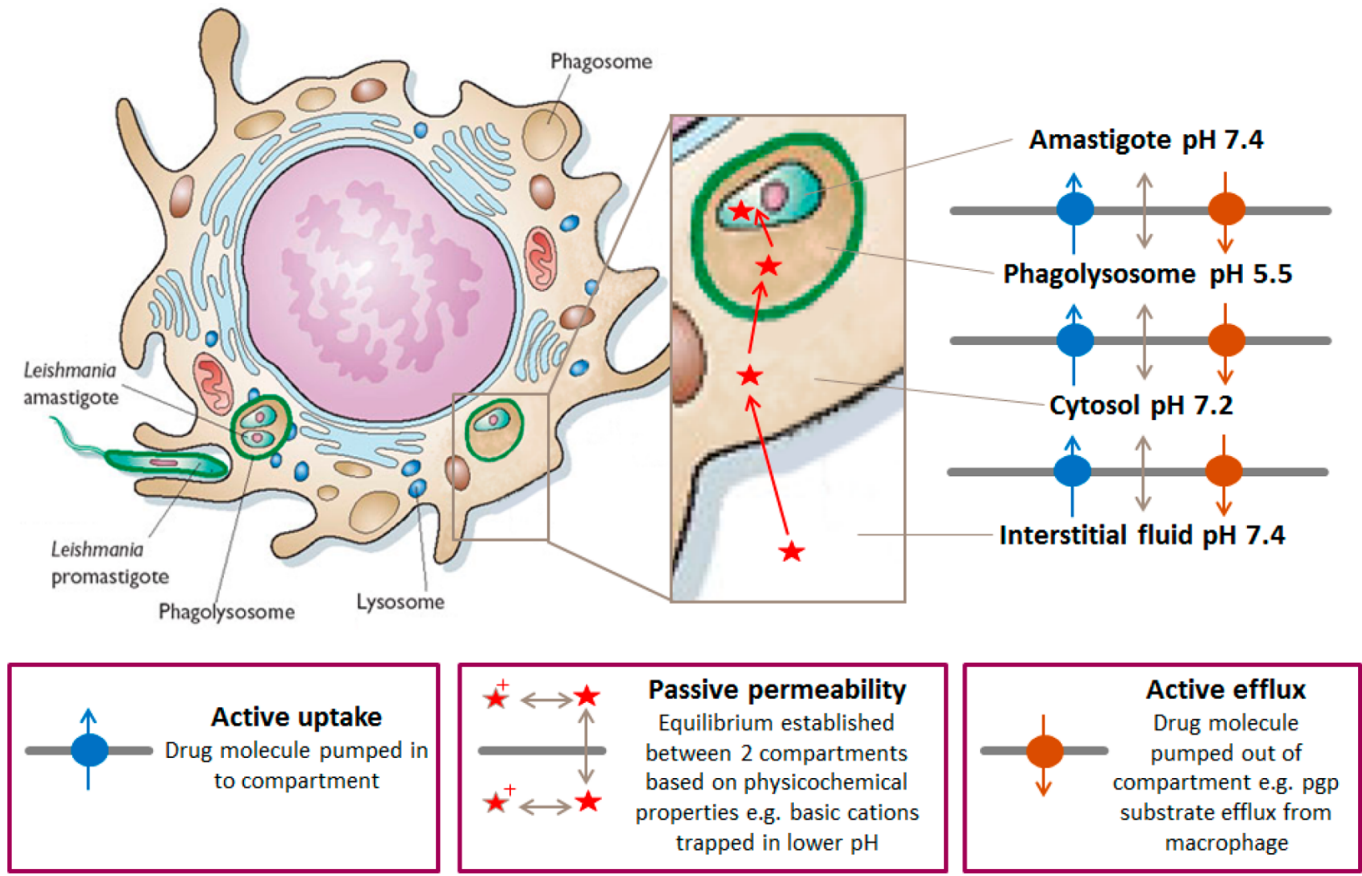

Figure 1. Reaching the biophase for visceral leishmania within macrophages. Reprinted (adapted) with permission from ref 47. Copyright 2002 Nature Publishing Group.

cases each year and approximately 20000-30000 deaths. ${ }^{3}$ Current therapies are not fit for use in resource-poor settings due to a combination of issues such as difficult administration, length of treatment, side effects, teratogenicity, cost, resistance, and/or clinical relapse. $^{4-7}$ At the time of this work, the external development pipeline for VL was sparse with only two additional new chemical entities (NCEs) just entering the early preclinical phase. ${ }^{8}$ Therefore, there was a clear unmet medical need for a new therapeutic class.

The primary objective of a collaboration between the Drug Discovery Unit, University of Dundee and GSK (funded by Wellcome), has been to identify safe, effective, oral, and shortcourse (ideally $\leq 10$ days) drug candidates for VL, in line with the DNDi (Drugs for Neglected Disease initiative) target product profile. ${ }^{9}$ Hence, the focus was to identify orally available compounds that demonstrate both in vitro and in vivo parasite suppression comparable to miltefosine (the only available oral therapy) in preclinical models, with an appropriate safety profile. This strategy of focusing on parasite suppression has been used successfully for discovery of most of the current protozoan chemotherapies. ${ }^{10}$ Because there are very few fully validated druggable targets in the kinetoplastids, most groups have focused on phenotypic approaches. ${ }^{11,12}$

Leishmania parasites have a complex life cycle, involving a vector (sandfly) stage and a host (human) stage. ${ }^{13}$ Given the differences in biology between the vector and the host stage, it is important that compounds are screened against the correct physiological stage (amastigotes). In the human host, the parasites are found within macrophages, more specifically within parasitophorous vacuoles where the $\mathrm{pH}$ is $\sim 5.5$. A high-content screening method for this stage was recently developed, where the parasites are cultured in differentiated THP-1 cells, representative of the human disease. ${ }^{14}$ In the experience of this collaboration and others, ${ }^{15}$ the hit rate was very low using this whole cell in vitro intracellular amastigote assay, which may be for several reasons. First, the parasites are dividing relatively slowly in this assay, and second, compounds need to cross three membranes and navigate two changes in $\mathrm{pH}$ to demonstrate in vitro potency (Figure 1). However, the assay only identifies cytocidal, rather than cytostatic compounds, which is an important consideration when identifying new compound series. Notably, all compounds which are either in the clinic, or in clinical development, exhibit activity in this assay. ${ }^{14}$

This publication details the lead optimization of a N1- $(1 \mathrm{H}-$ pyrazolo [3,4-d]pyrimidin-6-yl)cyclohexyl-1,4-trans-diamine series to find an appropriate balance between potency, relevant measures of solubility, and/or metabolic stability. This effort led to the in vivo profiling of a number of analogues, and finally the identification of precandidate asset GSK3186899/DDD853651, 1(Figure 2). ${ }^{16,17}$ Subsequent target deconvolution identified that the principal target was Cdc2-related kinase 12 (CRK12), ${ }^{17}$ although this was unknown during the lead optimization program.

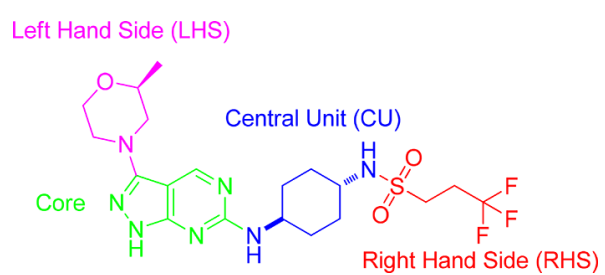

Figure 2. Structure of GSK3186899/DDD853651, 1.

\section{RESULTS AND DISCUSSION}

We previously reported that diaminothiazole 2 demonstrated activity against the related parasite Trypanosoma brucei, $^{18}$ and that a scaffold-hopping strategy identified pyrazolopyrimidine 3 as having very weak activity against $L$. donovani $(\mathrm{Ld})$ axenic amastigotes, ${ }^{17}$ albeit with no activity against intracellular parasites. Several changes were made to the cyclohexyl ring of 3 to allow us to explore the SAR around this portion of the 
Table 1. In Vitro Profile of 2-4

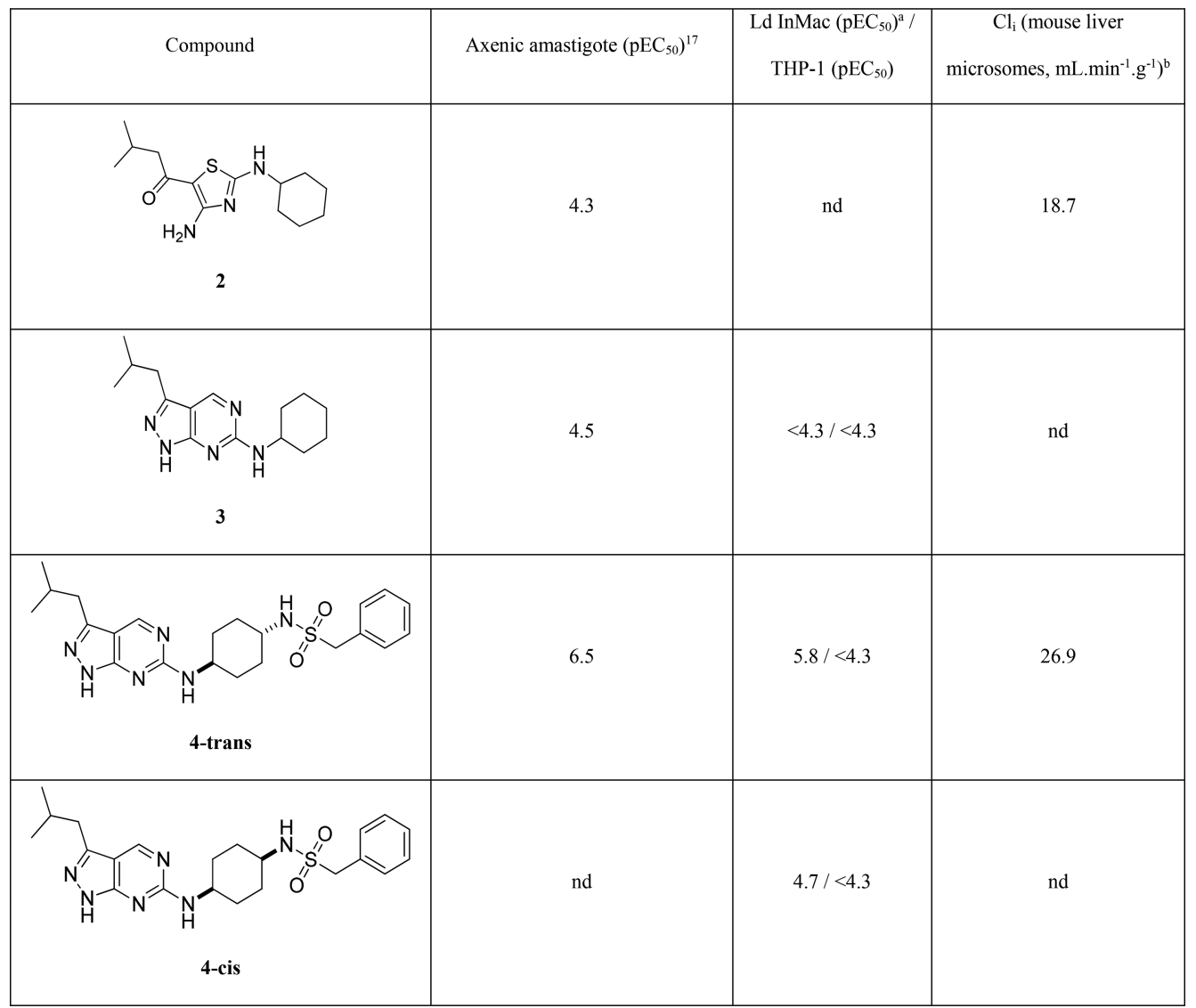

${ }^{a} \mathrm{Ld}$ InMac is the intramacrophage assay carried out in THP- 1 cells with $L$. donovani amastigotes. ${ }^{14}$ Data are the result of three replicates. ${ }^{b} \mathrm{Cl}_{\mathrm{i}}$ is mouse liver microsomal intrinsic clearance; nd is not determined.

molecule, and one such change, the introduction of a functionalized 4-amino group, led to compound 4-trans with in vitro potency against intracellular parasites and no effect on the nondividing human host cells (THP-1) (Table 1). Interestingly 4-cis was $>10$-fold less potent within the intramacrophage assay compared to 4-trans. This relationship was general across the series, and as such, the cis-isomers will not be discussed further.

On the basis of the data presented in Table 1 , the initial medicinal chemistry focus was to improve metabolic stability (mouse microsomal intrinsic clearance $<5 \mathrm{~mL} \cdot \mathrm{min}^{-1} \cdot \mathrm{g}^{-1}$ ), with the aim of rapidly identifying analogues suitable for testing in an in vivo mouse efficacy model. Despite the mode of action (MoA) of the series being unknown when the chemistry program was initiated, 3 and $\mathbf{4}$ did closely resemble a set of antitumor cyclin dependent kinase inhibitors. ${ }^{19}$ The closest exemplar was $\mathrm{N}$-(trans-4-((3-(5-fluoro-2-methoxyphenyl)-1Hpyrazolo $[3,4-d]$ pyrimidin-6-yl) a mino)cyclohexyl)methanesulfonamide (example 26 from ref 19), which demonstrated $\mathrm{IC}_{50}$ values of 0.199 and $0.114 \mu \mathrm{M}$ against Cdk4 and Cdk2, respectively. Repurposing of human kinase inhibitors as a strategy for infectious and neglected diseases has been explored by others, ${ }^{20-22}$ in which they all recognize selectivity over the human orthologue as a potential challenge. Therefore, monitoring against a panel of human kinases for this series would be critical, particularly for compounds progressing into in vivo efficacy experiments.
Interestingly, replacements for the sulphonamide (e.g. 5) were inactive against intracellular parasites within this series (Table 2). Exchanging the benzyl group with an iso-butyl group led to an increase in activity (6), although both compounds were metabolically unstable. Replacing the iso-butyl group (RHS) with a trifluoropropyl group (7) gave greater stability when incubated with mouse liver microsomes and only a small loss in potency compared to 6 . Switching focus to the LHS, it was noted that replacing the iso-butyl group with either a 2-methoxyphenyl or a 2-pyridyl caused a significant increase in potency (8 and 9), the latter being noteworthy for also having improved mouse metabolic stability. Additionally, this series demonstrated increased stability in human vs mouse liver microsomes (see $\mathbf{5}$ and $\mathbf{8}$ in Table 2).

To facilitate the synthesis of the compounds described within this paper, a set of key amines was synthesized according to Scheme 1. N-Boc-trans-1,4-cyclohexanediamine was deprotonated with $n$-BuLi then reacted with the relevant sulphonyl chloride, and the resulting Boc protected intermediates were treated with TFA to give $10 a-c$.

Examples 3-9, 15, and 17 were synthesized according to Scheme 2. Thus, 5-bromo-2-chloro-4-methoxypyrimidine was treated with iso-propylmagnesium chloride and various aldehydes at $-40{ }^{\circ} \mathrm{C}$. The resulting alcohols were oxidized with Dess-Martin periodinane to yield ketones 11a-d. Treatment of 11a with cyclohexylamine in the presence of Hünig's base led to aminopyrimidine 12. Similarly, 11a was treated with tert-butyl-(trans-4-aminocyclohexyl)carbamate, 
Table 2. In Vitro Profiles of 4-9

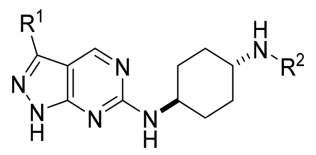

\begin{tabular}{|c|c|c|c|c|c|}
\hline Compound & $\mathrm{R}^{1}$ & $\mathrm{R}^{2}$ & $\begin{array}{l}\text { Ld InMac } \\
\left(\mathrm{pEC}_{50}\right)^{\mathrm{a}}\end{array}$ & $\begin{array}{l}\text { THP-1 }\left(\mathrm{pEC}_{50}\right) / \\
\text { HepG2 }\left(\mathrm{pEC}_{50}\right)^{\mathrm{b}}\end{array}$ & $\begin{array}{c}\mathrm{Cl}_{\mathrm{i}} \text { (liver microsomes, } \\
\left.\mathrm{mL} \cdot \mathrm{min}^{-1} \cdot \mathrm{g}^{-1}\right)^{\mathrm{c}}\end{array}$ \\
\hline 4-trans & & & 5.8 & $<4.3 /<4$ & 26.9 (mouse) \\
\hline 5 & & & $<4.3$ & $<4.3 / 4.3$ & $\begin{array}{l}9.5 \text { (mouse) } \\
1.9 \text { (human) }\end{array}$ \\
\hline 6 & & & 6.2 & $<4.3 / 4.2$ & 17.2 (mouse) \\
\hline 7 & & & 5.9 & $<4.3 / 4.3$ & 3.6 (mouse) \\
\hline 8 & & & 7.7 & $<4.3 /<4$ & $\begin{array}{l}48.0 \text { (mouse) } \\
14.1 \text { (human) }\end{array}$ \\
\hline 9 & & & 7.1 & $4.3 /<4$ & 2.1 (mouse) \\
\hline
\end{tabular}

${ }^{a} \mathrm{Ld}$ InMac is the intramacrophage assay carried out in THP-1 cells with L. donovani amastigotes. ${ }^{14}$ Data are the result of at least four replicates. ${ }^{b} \mathrm{HepG} 2$ is a human liver cancer cell line. ${ }^{c} \mathrm{Cl}_{\mathrm{i}}$ is liver microsomal intrinsic clearance.

Scheme 1. Synthesis of Intermediates $10 a-c^{a}$<smiles>CC(C)(C)OC(=O)NC1CCC(N)CC1</smiles>

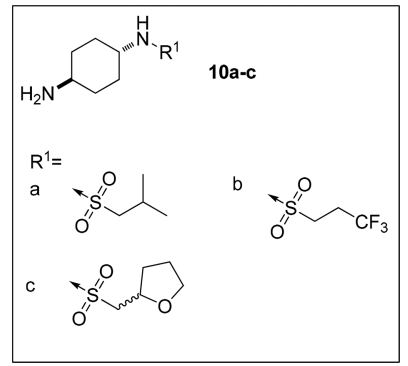

${ }^{a}$ Reagents and conditions: (a) $n-\mathrm{BuLi}, \mathrm{R}^{1} \mathrm{Cl}$, THF, $-78^{\circ} \mathrm{C}, 1-1.5 \mathrm{~h}$; (b) TFA, DCM, RT, overnight, $80-99 \%$ over 2 steps

and the resulting compound treated with TFA to remove the Boc group, yielding 13. This intermediate could then be either acylated or sulphonylated to give $\mathbf{1 4 a} \mathbf{a}, \mathbf{b}$. Alternatively, a more direct route was used for synthesis of intermediates $14 c-h$, whereby coupling of the appropriate combinations of $10 \mathrm{a}-\mathrm{c}$ with $11 a-d$ led to the relevant intermediates. Finally, treatment of either 12 or $14 a-h$ with hydrazine hydrate generated the desired target compounds (3-9, 15, and 17).

On the basis of the SAR learnings summarized in Table 2 (notably 7 and 9), compound $\mathbf{1 5}$ was prepared with the aim of improving potency and metabolic stability over 4 (Table 3 ). The in vitro profile of 15 supported progression into a mouse pharmacokinetic (PK) study. However, the compound showed poor solubility when measured using chemiluminescent nitrogen detection (CLND, a technique used to measure kinetic aqueous solubility). ${ }^{23}$ It would therefore be necessary to use a highly solubilizing vehicle (10\% (v/v) dimethyl sulfoxide (DMSO), 60\% polyethylene glycol 400 , and $30 \%$ deionized water) to maximize the chance of achieving sufficient exposure in mice when $\mathbf{1 5}$ was progressed to in vivo experiments.

To monitor the effects of the series on human kinases, chemoproteomic profiling on Kinobeads was performed in a K562 protein extract to identify potential human off-targets for 8 and 15 (Figure 3). The compounds were tested at a concentration of $5 \mu \mathrm{M}$ for their activity against 210 human protein kinases, and while $\mathbf{8}$ showed competition of several protein kinases, $\mathbf{1 5}$ did not affect any of the captured protein kinases. This gave us confidence that a suitable kinase selectivity profile could be achieved within this series. On the basis of this observation and overall in vitro/DMPK profile (Table 3), 15 was progressed to an animal disease model for VL.

There are a number of preclinical in vivo animal protocols available for assessing the efficacy of compounds intended to treat VL, including mouse, rat, hamster, dog, and monkey models. $^{24}$ Of these, mouse and hamster are the most common models for testing drug efficacy. ${ }^{25,26}$ However, there is a marked lack of clinical validation of these models and the absence of clinical PharmacoKinetic/PharmacoDynamic (PK/PD) data makes it impossible to suggest which model is more predictive of the clinical outcome in human. That said, after reviewing the available clinical data ${ }^{27,28}$ and comparing to our nonclinical in vivo data for miltefosine, it was observed that the mouse exposure data was predictive for humans. In addition, both liposomal amphotericin B and miltefosine achieve a $>95 \%$ suppression in parasite load within this mouse model. ${ }^{26}$ Mouse was therefore selected as our primary model to evaluate in vivo efficacy. 
Scheme 2. Synthesis of Compounds 3-9, 15, and $17^{a}$

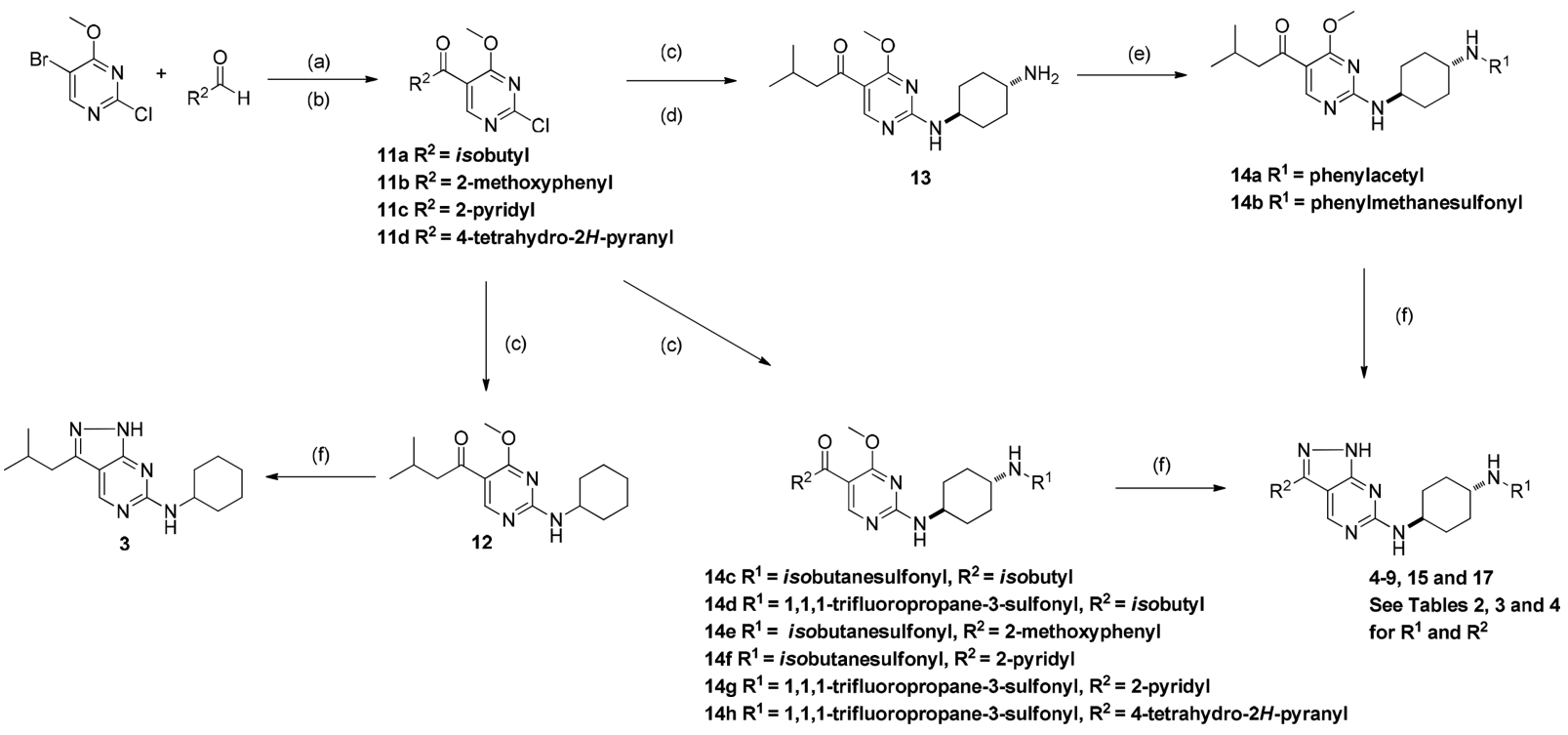

${ }^{a}$ Reagents and conditions: (a) $i \operatorname{PrMgCl}\left(2 \mathrm{M}\right.$ in $\mathrm{Et}_{2} \mathrm{O}$ ), THF, $-40^{\circ} \mathrm{C}, 30 \mathrm{~min}$; (b) Dess-Martin periodinane, DCM, RT, $1 \mathrm{~h}, 39-67 \%$ over two steps; (c) cyclohexylamine (for 12), tert-butyl-(trans-4-aminocyclohexyl)carbamate (for 13) or 10a-c (for 14c-h), DIPEA, EtOH, $120{ }^{\circ} \mathrm{C}$ (microwave, $2 \mathrm{~h}$ ); (d) TFA, DCM, $1 \mathrm{~h}, 80 \%$ over two steps; (e) phenylacetyl chloride, trimethylamine, DCM, overnight (for 14a), benzylsulphonyl chloride, $\mathrm{Cs}_{2} \mathrm{CO}_{3}$, DMF, overnight (for 14b); (f) hydrazine hydrate, EtOH, $150{ }^{\circ} \mathrm{C}$ (microwave), 30 min to $1 \mathrm{~h}, 30-72 \%$ over two steps.

Table 3. In Vitro Profile of 15

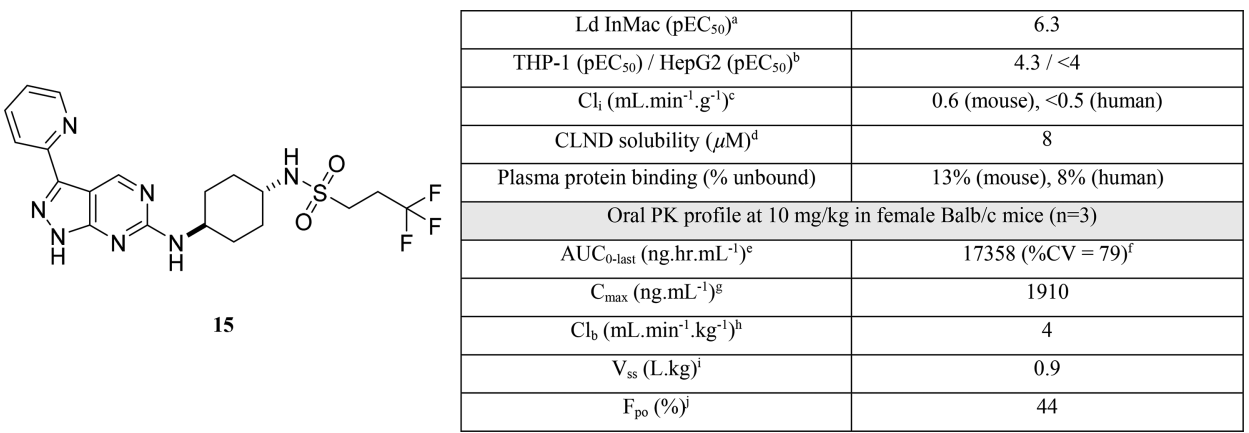

${ }^{a}$ Ld InMac is the intramacrophage assay carried out in THP-1 cells with L. donovani amastigotes. ${ }^{14}$ Data are the result of 18 replicates. ${ }^{b}$ HepG2 is a human liver cancer cell line. ${ }^{c} \mathrm{Cl}_{\mathrm{i}}$ is liver microsomal intrinsic clearance. ${ }^{d} \mathrm{CLND}$ is kinetic aqueous solubility measured using chemiluminescent nitrogen detection. ${ }^{23}{ }^{e} \mathrm{AUC}_{0-\text { last }}$ is the area under the curve until the last measurement. ${ }^{f_{\%}} \mathrm{CV}$ is the $\%$ of coefficient of variation. ${ }^{g} C_{\max }$ is the maximum concentration reached. ${ }^{h} \mathrm{Cl}_{\mathrm{b}}$ is mouse clearance in blood. ${ }^{i} V_{\mathrm{ss}}$ is volume of distribution at steady state. ${ }^{j} F_{\mathrm{po}}$ is oral bioavailability.

Female Balb/c mice were infected with $L$. donovani amastigotes, and the infection was allowed to establish for 7 days. These mice (groups of 5) were treated with either vehicle (oral), sodium stibogluonate (pentostam, $15 \mathrm{mg} / \mathrm{kg}$, which is the $\mathrm{ED}_{30}$, subcutaneously), miltefosine $(12 \mathrm{mg} / \mathrm{kg}$, which is the $\mathrm{ED}_{70}$, orally) as standards, or $\mathbf{1 5}(50 \mathrm{mg} / \mathrm{kg}$, orally). Pentosam and miltefosine were dosed once daily for 5 days with vehicle and 15 dosed twice daily over same period.

Fourteen days, after infection, all animals were humanely euthanized and parasite burden was determined microscopically. ${ }^{29}$ Parasite burden was expressed in Leishman-Donovan units (LDU), the number of amastigotes per 500 nucleated cells multiplied by the organ weight in grammes. ${ }^{30}$

Pleasingly, 15 demonstrated an $85 \%$ suppression in parasite load (Figure 4) within the liver with $50 \mathrm{mg} / \mathrm{kg}$ b.i.d. dosing for 5 days, while the controls performed as expected. This result established excellent proof of concept for the series. Despite $\mathbf{1 5}$ demonstrating promising efficacy and oral bioavailability (44\%), marked variability in exposure was observed $(\% \mathrm{CV}=79$, Table
3) and it was also noted that first pass metabolism could only account for $3 \%$ of the remaining noncirculating parent compound (56\%). Because 15 had a high artificial membrane permeability $\left(4.4 \times 10^{-5} \mathrm{~cm} / \mathrm{s}\right)$ and low CLND solubility (Table 3 ), it was hypothesized that increasing the solubility should increase exposure and reduce variability.

The property forecast index (PFI) provides a probabilistic score of the likely developability risks and solubility of compounds. ${ }^{31} 15$ had a PFI of 7.2 and the impact of modulating PFI by either introducing polarity (reducing ChromLogD) or incorporating saturated isosteres (reducing \#Ar) are highlighted in Table 4. A collateral benefit of reducing the PFI was that 15 and subsequent molecules all displayed excellent metabolic stability.

16 was synthesized according to Scheme 3, where commercially available 3-bromo-6-(methylthio)- $1 \mathrm{H}$-pyrazolo$[3,4-d]$ pyrimidine was oxidized to sulphone 22 . The pyrazole $\mathrm{N}-\mathrm{H}$ of $\mathbf{2 2}$ was then protected with THP to yield $\mathbf{2 3}$, and the sulphone was subsequently displaced with $\mathbf{1 0 b}$. The resulting 


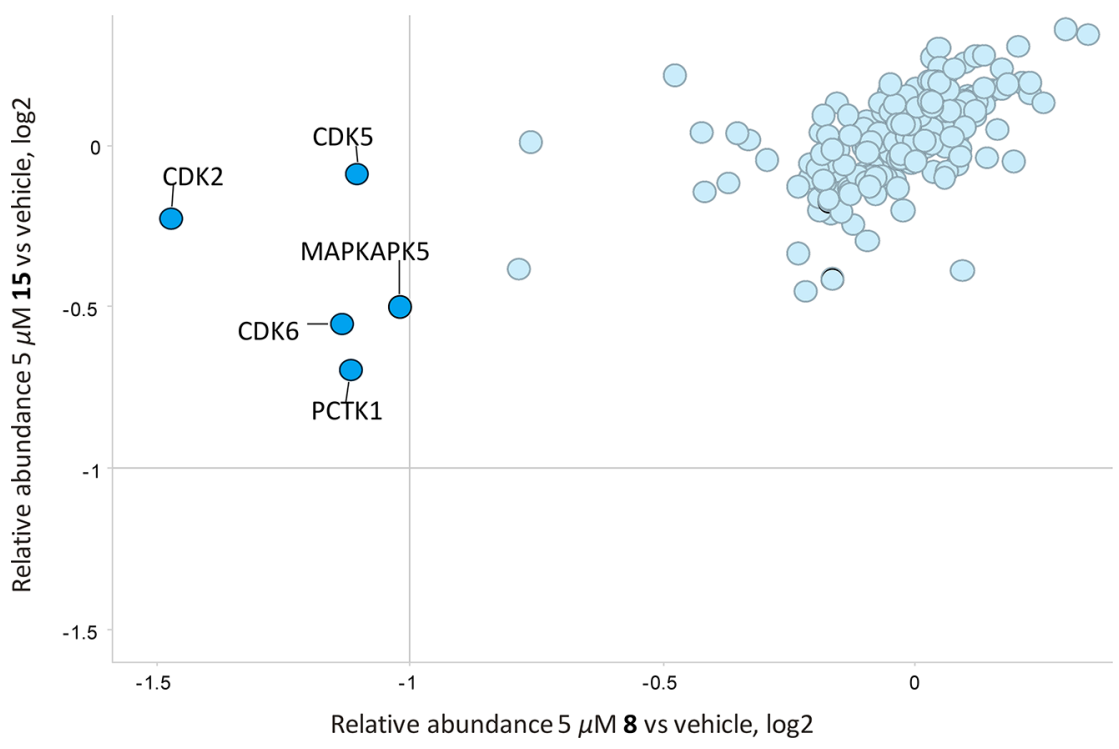

Figure 3. Chemoproteomic affinity profiling of compounds 8 and 15. Kinobeads were incubated with K-562 cell extract either in the presence of vehicle (DMSO) or compound 15 or compound $8(5 \mu \mathrm{M})$. Proteins captured by the beads in both conditions were quantified by LC-MS/MS analysis. Labeled proteins show more than 2 -fold reduced binding to the Kinobead matrix due to competition with compounds $\mathbf{1 5}$ or $\mathbf{8}$ against vehicle respectively and represent potential human off-targets.

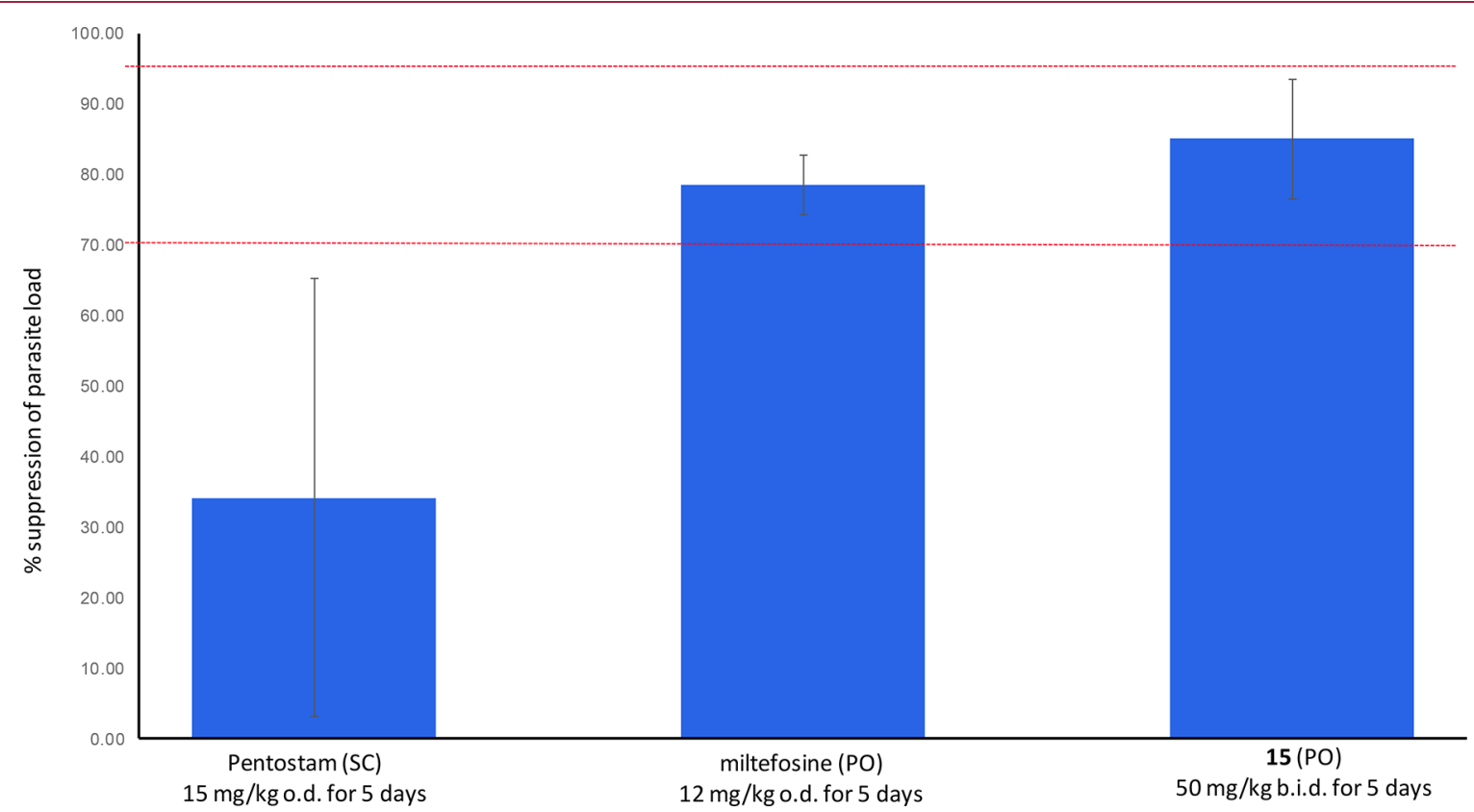

Figure 4. In vivo efficacy profile of pentostam, miltefosine, and 15. The mean LDU values from individual animal livers were compared to the control to give the percentage (\%) suppression of parasite load in Balb/c mice (that were infected with $L$. donovani). Error bars represent the standard deviation (SD). Lead optimization criteria was $70 \%$ suppression in liver parasite burden, while preclinical candidate was $>95 \%$.

bromide 24 was reacted with 5-pyrimidylboronic acid using Suzuki coupling conditions, and subsequent THP deprotection led to 16.

17 was synthesized according to Scheme 2, whereas an alternative route was required for compounds 18-21. Synthesis of these derivatives, along with 1 and 36-38, was accomplished according to Scheme 4. Commercially available 2,4-dichloro-5pyrimidinecarbonyl chloride was treated with a suitable amine to give amides $26 \mathbf{a}-\mathbf{g}$, which were subsequently treated with sodium methoxide to selectively displace the pyrimidinyl 4chloro yielding $27 \mathbf{a}-\mathbf{g}$. The pyrimidinyl 2-chloro group could then be displaced with amine $10 \mathrm{a}$ or $10 \mathrm{~b}$ to give $28 \mathrm{a}-\mathrm{g}$. Finally, reaction of $28 \mathbf{a}-\mathbf{g}$ with Lawesson's reagent followed by treatment with hydrazine gave compounds 1, 18-21, and $36-38$. In the case of $29 \mathrm{f}$, the Boc group was deprotected with TFA following the reaction with hydrazine to give 20. Chiral separation of 29c furnished the enantiomers 36 and 37.

Several LHS heteroaromatic analogues were synthesized. However, as demonstrated by $\mathbf{1 6}$, none showed any advantage over $\mathbf{1 5}$ in terms of either solubility or potency (Table 4). Hence, the focus was to identify saturated isosteres to replace the pyridyl LHS in 15, thus reducing the number of aromatic rings. Initial compounds 17 and 18, where the pyridyl was replaced by a saturated ring to reduce PFI, showed an improvement in solubility, although both were less potent than 15. Pyrrolidine 19 demonstrated similar in vitro potency to piperidine 18 , albeit 
Table 4. PFI and in Vitro Profiles of 16-21

\begin{tabular}{|c|c|c|c|c|c|}
\hline Compound & $\mathrm{R}^{1}$ & $\begin{array}{l}\text { Ld InMac } \\
\left(\mathrm{pEC}_{50}\right)^{\mathrm{a}}\end{array}$ & $\begin{array}{c}\text { Solubility } \\
(\mathrm{CLND}, \mu \mathrm{M})^{\mathrm{b}}\end{array}$ & $\mathrm{PFI}^{\mathrm{c}}$ & $\begin{array}{c}\text { Chrom } \log \mathrm{D}_{\mathrm{pH} 7.4}{ }^{\mathrm{d}} / \\
\text { no. of } \mathrm{Ar}\end{array}$ \\
\hline 16 & & 5.2 & 11 & 6.0 & $3.0 / 3$ \\
\hline 17 & & 5.5 & 35 & 5.2 & $3.2 / 2$ \\
\hline 18 & & 5.8 & 46 & 6.4 & $4.4 / 2$ \\
\hline 19 & & 5.7 & 12 & 6.0 & $4.0 / 2$ \\
\hline 20 & & 4.5 & 346 & 3.6 & $1.6 / 2$ \\
\hline 21 & & 5.5 & 259 & 5.0 & $3.0 / 2$ \\
\hline
\end{tabular}

${ }^{a}$ Ld InMac is the intramacrophage assay carried out in THP-1 cells with $L$. donovani amastigotes. ${ }^{14}$ Data are the result of at least three replicates. ${ }^{b}$ CLND is kinetic aqueous solubility measured using chemiluminescent nitrogen detection. ${ }^{23}{ }^{c}$ PFI is the property forecast index. ${ }^{31}$ ${ }^{d}$ ChromLogD $\mathrm{pH}_{\mathrm{pH} .4}$ is a measure lipophilicity at $\mathrm{pH} 7.4 .^{31}$

Scheme 3. Synthesis of Compound $16^{a}$

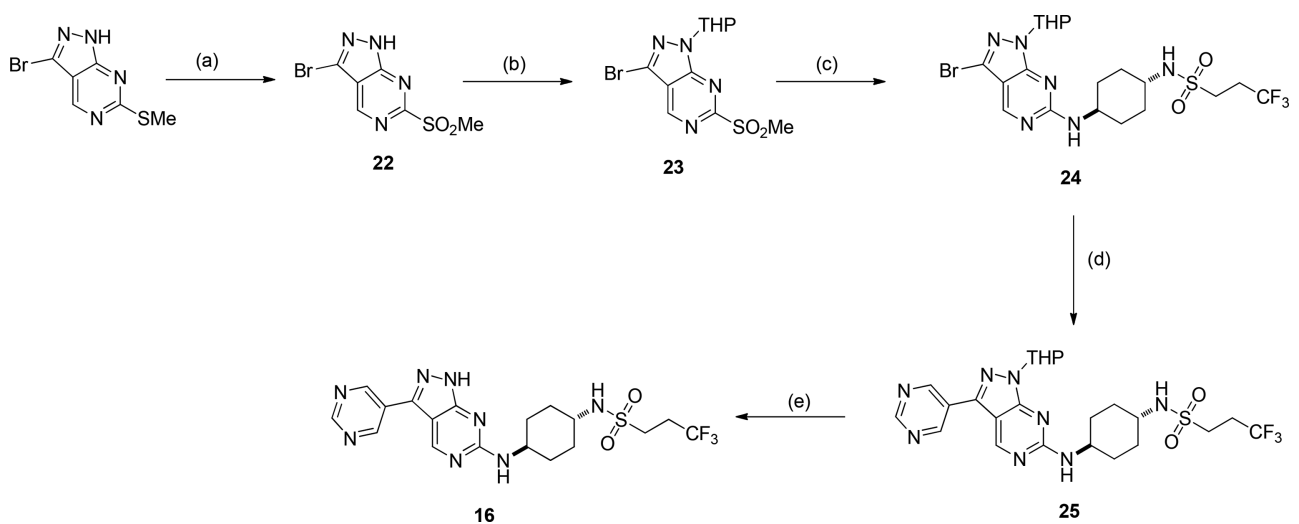

${ }^{a}$ Reagents and conditions: (a) oxone, $\mathrm{MeCN}, \mathrm{H}_{2} \mathrm{O}, \mathrm{RT}, 3 \mathrm{~h}, 62 \%$; (b) 3,4-dihydro-2H-pyran, $p$-toluenesulfonic acid monohydrate, THF, reflux,

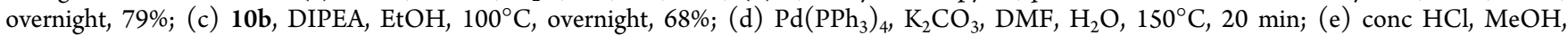
$100^{\circ} \mathrm{C}, 30 \mathrm{~min}, 85 \%$ over two steps.

lower solubility. Interestingly, piperazine 20 was less potent but had excellent CLND solubility, presumably due to increased basicity and reduced ChromLogD. Interrogation of the data (Figure 5) suggested targeting a PFI between 4.2 and 6 would give a high probability of achieving a desirable CLND solubility while maintaining intracellular potency and good absorption.

Promisingly, the morpholine analogue $\mathbf{2 1}$ in Table 4 showed similar in vitro potency to piperidine $\mathbf{1 8}$ with reduced PFI and increased CLND solubility. Knowing that an improvement in potency (in vitro) between compounds 9 and $\mathbf{1 5}$ was observed, the iso-butyl-sulphonamide version of morpholine analogue $\mathbf{2 1}$ was of interest. This compound (30) was synthesized following Scheme 4, i.e., displacing the chloro of $\mathbf{2 7} \mathbf{g}$ with amine $\mathbf{1 0 a}$. As shown in Table 5, 30 demonstrated excellent in vitro potency and CLND solubility, additionally showing a similar profile to 
Scheme 4. Synthesis of Compounds $1,18-21,30$, and $36-38^{a}$<smiles>COc1nc(Cl)ncc1C(=O)CC(C)C</smiles>

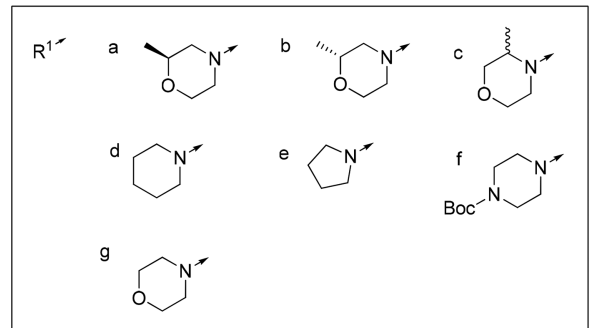

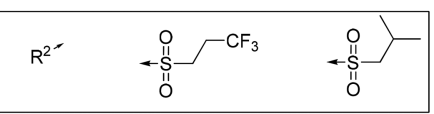<smiles>[R]C(=O)c1cnc(NC2CCC(NC)CC2)nc1OC</smiles>

(d)<smiles>[R]C(=S)c1cnc(NC2CCC(N)CC2)nc1OC</smiles>

(e)

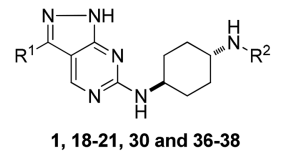

For $R^{1} / R^{2}$ see Tables 4 and 9

${ }^{a}$ Reagents and conditions: (a) $\mathrm{R}^{1} \mathrm{H}$, DIPEA, DCM, $0^{\circ} \mathrm{C}, 3 \mathrm{~h}, 53-92 \%$; (b) NaOMe, THF, $-40^{\circ} \mathrm{C}, 3 \mathrm{~h}, 48-86 \%$; (c) 10a or 10b, DIPEA, 1,4dioxane, $100^{\circ} \mathrm{C}$, overnight, 54-71\%; (d) Lawesson's reagent, THF, $45^{\circ} \mathrm{C}, 2 \mathrm{~h}$; (e) hydrazine hydrate, 1,4-dioxane, $90{ }^{\circ} \mathrm{C}$, overnight, $47-58 \%$ over two steps.

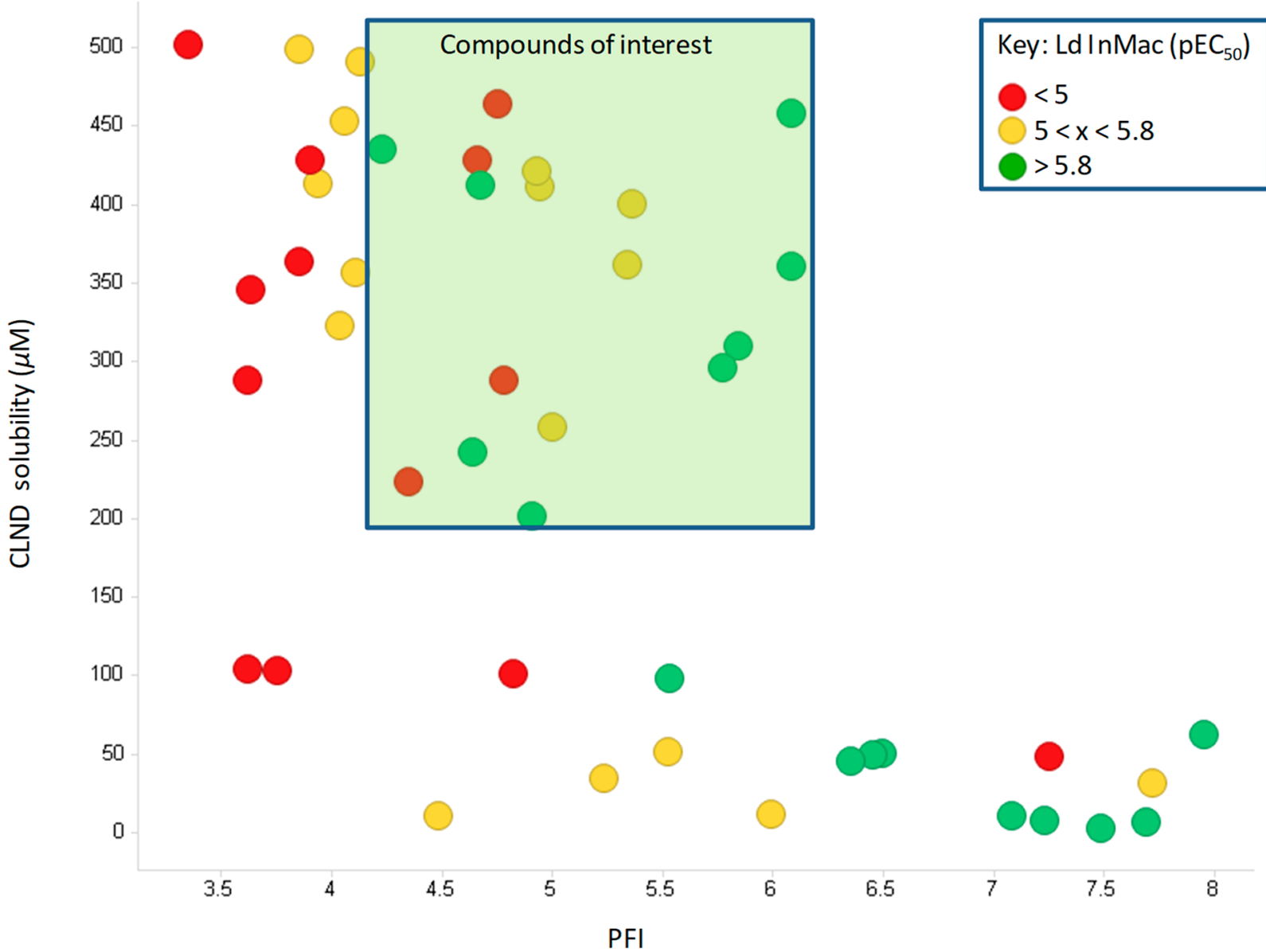

Figure 5. CLND solubility vs PFI profile within this series of compounds. Ld InMac is the intramacrophage assay carried out in THP-1 cells with $L$. donovani amastigotes. ${ }^{14}$ Number of biological replicates for all active compounds $\geq 2$; PFI is the property forecast index; ${ }^{31}$ CLND is kinetic aqueous solubility measured using chemiluminescent nitrogen detection. ${ }^{23}$ 
Table 5. In Vitro Profile of 30

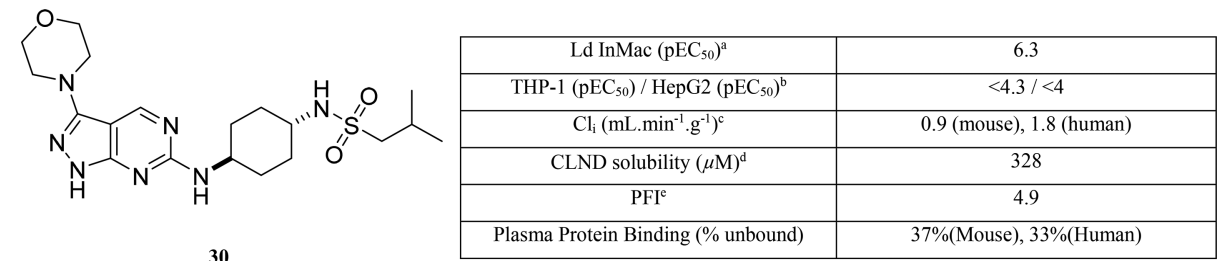

${ }^{a} \mathrm{Ld}$ InMac is the intramacrophage assay carried out in THP-1 cells with $L$. donovani amastigotes. ${ }^{14}$ Data are the result of at least eight replicates. ${ }^{b}$ HepG2 is a human liver cancer cell line. ${ }^{c} \mathrm{Cl}_{\mathrm{i}}$ is liver microsomal intrinsic clearance. ${ }^{d} \mathrm{CLND}$ is kinetic aqueous solubility measured using chemiluminescent nitrogen detection. ${ }^{23}{ }^{e} \mathrm{PFI}$ is the property forecast index. ${ }^{31}$

15 (Figure 3) against a panel of 210 human protein kinases at 5 $\mu \mathrm{M}$ (data not shown).

30 was selected for progression to the mouse in vivo efficacy model, and the greater solubility of $\mathbf{3 0}$ compared to $\mathbf{1 5}$ now allowed use of a vehicle that was suitable for subsequent toxicology studies (i.e., 0.5\% HPMC, 0.4\% Tween 80 and $0.5 \%$ benzyl alcohol) and investigation of higher doses within the model.

Analogue 30 demonstrated in vivo efficacy very close to our preclinical candidate target (i.e., $>95 \%$ parasite suppression) at $100 \mathrm{mg} / \mathrm{kg}$ b.i.d. for 5 days, and a dose response study utilizing a 10 day regimen showed that a dose of $50 \mathrm{mg} / \mathrm{kg}$ b.i.d. achieved the same level of efficacy (Table 6).

\section{Table 6. Mouse in Vivo Efficacy Profile of $30^{a}$}

$\begin{array}{lcc}\text { oral regimen of 30 } & \begin{array}{c}\text { \% suppression of parasite load } \\ \text { compared to the control group }\end{array} & \begin{array}{c}\text { standard } \\ \text { deviation (SD) }\end{array} \\ \begin{array}{c}100 \mathrm{mg} / \mathrm{kg} \text { b.i.d. } \\ \text { for } 5 \text { days }\end{array} & 94 & 5.24 \\ 10 \mathrm{mg} / \mathrm{kg} \text { b.i.d. for } & 36 & 27.31 \\ \quad 10 \mathrm{days} & & \\ 25 \mathrm{mg} / \mathrm{kg} \text { b.i.d. for } & 74 & 4.49 \\ 10 \mathrm{days} & & 0.95 \\ 50 \mathrm{mg} / \mathrm{kg} \text { b.i.d. for } & 97 & \\ 10 \text { days } & & \end{array}$

${ }^{a_{\text {The }}}$ vehicle was $0.5 \%$ HPMC, $0.4 \%$ Tween 80 and $0.5 \%$ benzyl alcohol using 5 mice per dose level.

Table 7. PK Dose Escalation in Rats for 30

$\begin{array}{cc}\text { dose of } \mathbf{3 0}(\mathrm{mg} / \mathrm{kg}) & \text { mean } \mathrm{AUC}_{0-\text { last }} \mathrm{h} \cdot \mathrm{ng} / \mathrm{mL}\left(\% \mathrm{CV}^{a}\right) \\ 10 & 162(41) \\ 100 & 2960(33) \\ 300 & 2383(183)\end{array}$

$a_{\%} \mathrm{CV}$ is the $\%$ of coefficient of variation. The vehicle was $1 \%$ methylcellulose in aqueous buffer using three rats per dose level.

A rat PK dose escalation study with 30 (Table 7) disappointingly showed greater than proportional increase in exposure between 10 and $100 \mathrm{mg} / \mathrm{kg}$ and then a saturation of absorption between 100 and $300 \mathrm{mg} / \mathrm{kg}$ limiting the maximum exposure that could be explored. This saturation of absorption at higher doses, together with high variability between animals, implied that solubility might still be problematic. Although $\mathbf{3 0}$ showed reasonable CLND solubility data (Table 5), the solubility profile in fasted state simulated intestinal fluid (FaSSIF $)^{32}$ was poor $(9 \mu \mathrm{g} / \mathrm{mL})$. Other compounds within this series all showed a similar poor level of FaSSIF solubility (see 15, 21, and 30 in Table 8) except for $\mathbf{3 1} \mathbf{1}^{33}$ (see Table 9 for structure), which had an improved profile (more discussion on 31 to follow). Care should always be taken when considering
Table 8. Profile of 15, 21, 30, and 31

$\begin{array}{lllll} & \mathbf{1 5} & \mathbf{2 1} & \mathbf{3 0} & \mathbf{3 1} \\ \text { CLND solubility }(\mu \mathrm{M})^{a} & 8 & 259 & 328 & 68 \\ \text { FaSSIF }(\mu \mathrm{g} / \mathrm{mL})^{b} & <1 & 7 & 9 & 130 \\ \mathrm{PFI}^{c} & 7.2 & 5.0 & 4.9 & 8.0 \\ \mathrm{pK}_{\mathrm{a}}{ }^{d} & 3.2 & 3.7 & \text { nd } & 4.1 \\ \text { melting point }\left({ }^{\circ} \mathrm{C}\right) & \text { nd } & 273 & 218 & 135\end{array}$

${ }^{a}$ CLND is kinetic aqueous solubility measured using chemiluminescent nitrogen detection. ${ }^{23}{ }^{b} \mathrm{FaSSIF}$ is fasted state simulated intestinal fluid solubility. ${ }^{32}{ }^{c}$ PFI is the property forecast index. ${ }^{31} d \mathrm{pK}$ a is the negative $\log _{10}$ of acid dissociation constant. ${ }^{35}$ nd is not determined.

FaSSIF solubility as variability between batches is known. ${ }^{34}$ However, within this series of compounds, minimal FaSSIF variability was observed within the same batch and for $\mathbf{3 1}$ there was little variation between the lead optimization batches (see Table S20 in Supporting Information). Also, these compounds demonstrated that there was little correlation between FaSSIF and PFI or CLND within this series (see Table 8). Although different $\mathrm{pH}$ conditions were used to measure FaSSIF ( $\mathrm{pH}$ 6.5) and PFI or CLND ( $\mathrm{pH} 7.4$ ), the measured $\mathrm{pK}_{\mathrm{a}}$ values ${ }^{35}$ of these compounds would suggest that the degree of protonation should have been similar under these different $\mathrm{pH}$ conditions.

Reviewing the general solubility equation (GSE, Yalkowsky and co-workers $)^{36}$ which relates lipophilicity and melting point to aqueous solubility (see eq 1 ), highlighted the importance of the melting point of the compound on its solubility.

$$
\log S=0.5-0.01(\mathrm{MP}-25)-\log P
$$

Equation 1: The general solubility equation (GSE), where $S$ is solubility, MP is melting point in Celsius, and $P$ is octanol-water partition coefficient. In practice, the GSE is commonly used where $\log P$ is replaced by $\log D_{\mathrm{pHx}}$, meaning $\log S$ is strictly $\log$ $\mathrm{S}_{\mathrm{pHx}} \cdot{ }^{37}$

Data in Table 8 indicates a reciprocal trend between melting point and FaSSIF solubility. To explore the potential means of modulating the high melting points, a small molecule crystal structure of $\mathbf{1 5}$ (Figure 6, as a representative example of the series) was obtained.

The crystal structure of $\mathbf{1 5}$ was shown to contain a single, fully ordered molecule in the centrosymmetric space group, $P \overline{1}$. As can be seen in Figure 6, all three N-H groups act as hydrogen bond donors. Molecules of $\mathbf{1 5}$ form hydrogen-bonded dimers through reciprocal $\mathrm{N} 20-\mathrm{H} 20 \cdots \mathrm{N} 19$ interactions between inversion symmetry-related fused ring systems. These dimers are linked together by further hydrogen bonds between the sulfonamide and aminopyrimidine groups to form hydrogenbonded columns within the structure. Additionally, the fused ring system and the pyridine in each molecule of $\mathbf{1 5}$ are 
Table 9. In Vitro and FaSSIF Solubility Profiles of 1 and 31-40<smiles>[R]c1n[nH]c2nc(NC3CCC(NS([R])(=O)=O)CC3)nc([R])c12</smiles>

\begin{tabular}{|c|c|c|c|c|c|c|}
\hline Compound & $\mathbf{R}^{1}$ & $\mathbf{R}^{2}$ & $\mathbf{R}^{3}$ & $\operatorname{Ld} \operatorname{InMac}\left(\mathrm{pEC}_{50}\right)^{\mathrm{a}}$ & $\begin{array}{c}\text { CLND }(\mu \mathrm{M})^{\mathrm{b}} / \\
\text { FaSSIF }(\mu \mathrm{g} / \mathrm{mL})^{\mathrm{c}}\end{array}$ & $\begin{array}{c}\mathrm{PFI}^{\mathrm{d} /} \\
\text { melting point }\left({ }^{\circ} \mathrm{C}\right)\end{array}$ \\
\hline 31 & & & $\mathrm{OMe}$ & 6.4 & $68 / 130$ & $8.0 / 135$ \\
\hline 32 & & & $\mathrm{OMe}$ & 5.9 & $311 / 53$ & $5.8 / \mathrm{nd}$ \\
\hline 33 & & & $\mathrm{OMe}$ & 6.7 & $258 / 16$ & $5.8 / 217$ \\
\hline $\begin{array}{c}\text { 34, single unknown } \\
\text { enantiomer } 1\end{array}$ & & & $\mathrm{OMe}$ & 5.4 & $412 / 283$ & $4.9 / 81$ \\
\hline $\begin{array}{c}\text { 35, single unknown } \\
\text { enantiomer } 2\end{array}$ & & & $\mathrm{OMe}$ & 5.2 & $421 / 208$ & $4.9 / 79$ \\
\hline $\begin{array}{l}\text { 36, single unknown } \\
\text { enantiomer } 1\end{array}$ & & & $\mathrm{H}$ & 5.6 & $\geq 310 / 88$ & $5.4 / 219$ \\
\hline $\begin{array}{l}\text { 37, single unknown } \\
\text { enantiomer } 2\end{array}$ & & & $\mathrm{H}$ & 5.7 & $\geq 292 / 118$ & $5.4 / \mathrm{nd}$ \\
\hline 1 & & & $\mathrm{H}$ & 5.9 & $99 / 64$ & $5.5 / \mathrm{nd}$ \\
\hline 38 & & & $\mathrm{H}$ & 5.3 & $52 / 23$ & $5.5 / 263$ \\
\hline 39 & & & $\mathrm{OMe}$ & 6.6 & $\geq 382 / 50$ & $6.1 / 127$ \\
\hline 40 & & & $\mathrm{OMe}$ & 6.0 & $\geq 365 / 87$ & $6.1 / 125$ \\
\hline
\end{tabular}

${ }^{a} \mathrm{Ld}$ InMac is the intramacrophage assay carried out in THP-1 cells with L. donovani amastigotes. ${ }^{14}$ Data are the result of at least three replicates. ${ }^{b}$ CLND is kinetic aqueous solubility measured using chemiluminescent nitrogen detection. ${ }^{23}{ }^{c} \mathrm{FaSSIF}$ is fasted state simulated intestinal fluid solubility. ${ }^{32}$ PFI is the property forecast index. ${ }^{31} \mathrm{nd}$ is not determined.

approaching a coplanar arrangement [having a dihedral angle of $\left.6.18(8)^{\circ}\right]$, and this allows a $\pi-\pi$ interaction between adjacent molecules within the columns. As such, 15 exhibited a highly stacked crystal lattice, therefore potentially explaining the low FaSSIF solubility. A number of analogues were therefore designed that would disrupt some of the hydrogen bonding seen in this crystal structure. From the past SAR, removal of N19 or N20-H (Figure 6) meant significant in vitro potency reduction (i.e., the $\mathrm{N} 20-\mathrm{Me}$ version of compound $\mathbf{1 5}$ demonstrated Ld InMac $\mathrm{pEC}_{50}<4.3$ and THP $\mathrm{pEC}_{50}<4.3$ ), so focusing on disruption of the other hydrogen bonds via introduction of strategically placed substituents was prioritized. A second strategy involved introducing substituents to reduce the overall planarity of this series, through either chiral centers or 


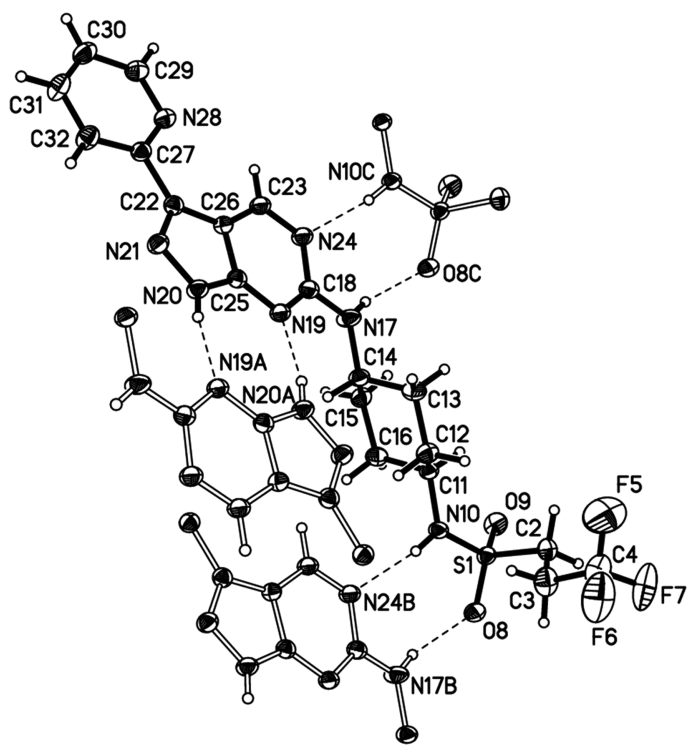

Figure 6. View of part of the crystal structure of $\mathbf{1 5}$. The numbering scheme for the non-hydrogen atoms of the central molecule (depicted with the solid bond type) is shown in full. The hydrogen bonds associated with the central molecule are depicted as dashed lines. For clarity, only fragments containing the hydrogen bond donors and acceptors are shown for the surrounding molecules (with the open bond type). Anisotropic atomic displacement ellipsoids for the nonhydrogen atoms are shown at the 50\% probability level. Hydrogen atoms are displayed with an arbitrarily small radius.

causing steric clashes. Indeed, some substituents could serve both of these desired functions and potentially improve the FaSSIF solubility (see Table 9).

The 4-methoxy- $1 H$-pyrazolo[3,4- $d]$ pyrimidin-6-amino derivatives 31-35 were synthesized according to Scheme 5 . Commercially available 3-bromo-4,6-dichloro- $1 \mathrm{H}$-pyrazolo$[3,4-d]$ pyrimidine was THP-protected and the 4-chloro selectively displaced with sodium methoxide to give 42a. Treatment of $42 \mathrm{a}$ with the appropriate amine $10 \mathrm{a}-\mathrm{c}$ in the presence of Hünigs base yielded $43 a-c$. Suzuki coupling of 43a with 2-methoxyphenylboronic acid or Buchwald-Hartwig coupling of $43 \mathrm{~b}, \mathrm{c}$ with morpholine, followed by deprotection of the THP group, furnished compounds 31-35. In the case of 44d, THP deprotection was followed by separation of the enantiomers by chiral chromatography to give 34 and 35 . To generate the more challenging 3-methylmorpholine analogues 39 and 40 , a range of protecting groups, $S_{N} A r$ conditions, and Buchwald-Hartwig coupling conditions were investigated. The conditions that gave the best results involved the use of SEM as the protecting group, which gave improved yields compared to THP. Subsequently, use of RuPhos as catalyst, tris(dibenzylideneacetone)dipalladium(0) as the palladium source, and potassium hexamethyldisilazide as base gave reasonable yields in the Buchwald-Hartwig coupling. Thus, treatment of 43d with the appropriate enantiomer of 3-methylmorpholine under these conditions gave $44 \mathbf{e}-\mathbf{f}$, with subsequent SEM deprotection yielding 39 and $\mathbf{4 0 .}$

As mentioned earlier, 31 (Tables 8 and 9) proved to be very interesting as it demonstrated that it was possible to identify compounds with improved FaSSIF solubility while maintaining intracellular potency. It was postulated that the additional methoxy group in the core could disrupt at least two or possibly four hydrogen bonds and/or force the phenyl ring to be out of the plane (Figure 6); in particular, it should disrupt the H-bonds formed by N17 and N24. As such, the addition of this OMe into the core of $\mathbf{2 1}(7 \mu \mathrm{g} / \mathrm{mL})$ and $\mathbf{3 0}(9 \mu \mathrm{g} / \mathrm{mL})$ was investigated in order to improve the FaSSIF solubility (see analogues 32 and 33 in Table 9). Pleasingly, both examples (32 and 33) demonstrated an increase in potency (in vitro), although only 32 showed an improvement in FaSSIF solubility compared to its corresponding parent compound (21).

Comparing 32 and 33 in more detail, it was postulated that variations to the sulphonamide could affect the distance between

Scheme 5. Synthesis of Compounds $31-35,39$, and $40^{a}$

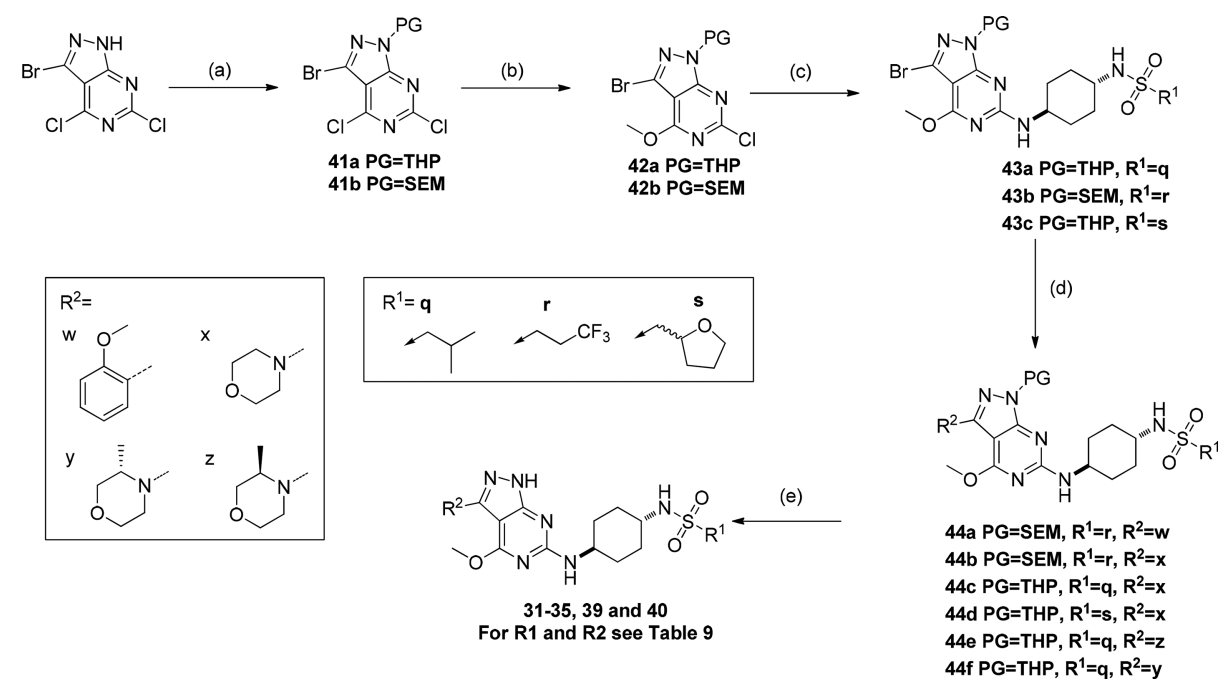

\footnotetext{
${ }^{a}$ Reagents and conditions: (a) For THP, 3,4-dihydro-2H-pyran, para-toluenesulfonic acid monohydrate, THF, 70 ${ }^{\circ} \mathrm{C}, 2 \mathrm{~h}, 79 \%$ (41a) or for SEM, 2 (trimethylsilyl)ethoxymethyl chloride, DIPEA, DCM, $0{ }^{\circ} \mathrm{C}, 1.5 \mathrm{~h}, 100 \%$ (41b); (b) NaOMe, MeOH, RT, $30 \mathrm{~min}, 100 \%$ (PG = THP, 42a) or 98\% $(\mathrm{PG}=\mathrm{SEM}, \mathbf{4 2 b})$; (c) 10a-c, DIPEA, 1,4-dioxane, $110^{\circ} \mathrm{C}$, 3 days, $40-51 \%$; (d) 2-methoxyphenylboronic acid, $\mathrm{Pd}\left(\mathrm{PPh}_{3}\right)_{4}, \mathrm{~K}_{2} \mathrm{CO}_{3}, \mathrm{DMF} 130^{\circ} \mathrm{C}$, 30 min for 44a $(87 \%)$ or morpholine, $\mathrm{NaO}{ }^{t} \mathrm{Bu}$, xantphos, $\mathrm{Pd}_{2} \mathrm{dba}_{3}$, dioxane, $110^{\circ} \mathrm{C}$, overnight for $44 \mathrm{~b}-\mathrm{d} 45-70 \%$, or relevant 3 methylmorpholine, KHMDS, RuPhos, $\mathrm{Pd}_{2} \mathrm{dba}_{3}, 1$,4-dioxane, $110^{\circ} \mathrm{C}, 2 \mathrm{~h}$ for $44 \mathrm{e}, \mathrm{f} 47-50 \%$; (e) $\mathrm{HCl}, \mathrm{MeOH}, 60^{\circ} \mathrm{C}, 30 \mathrm{~min}$ to $1 \mathrm{~h}(\mathrm{THP}$ deprotection of $\mathbf{4 4 a}-\mathbf{d}$ ) or $\mathrm{AcCl}, \mathrm{MeOH}, \mathrm{RT}, 30 \mathrm{~min}$ to $1 \mathrm{~h}$ (SEM deprotection of 44e,f) $32-83 \%$.
} 


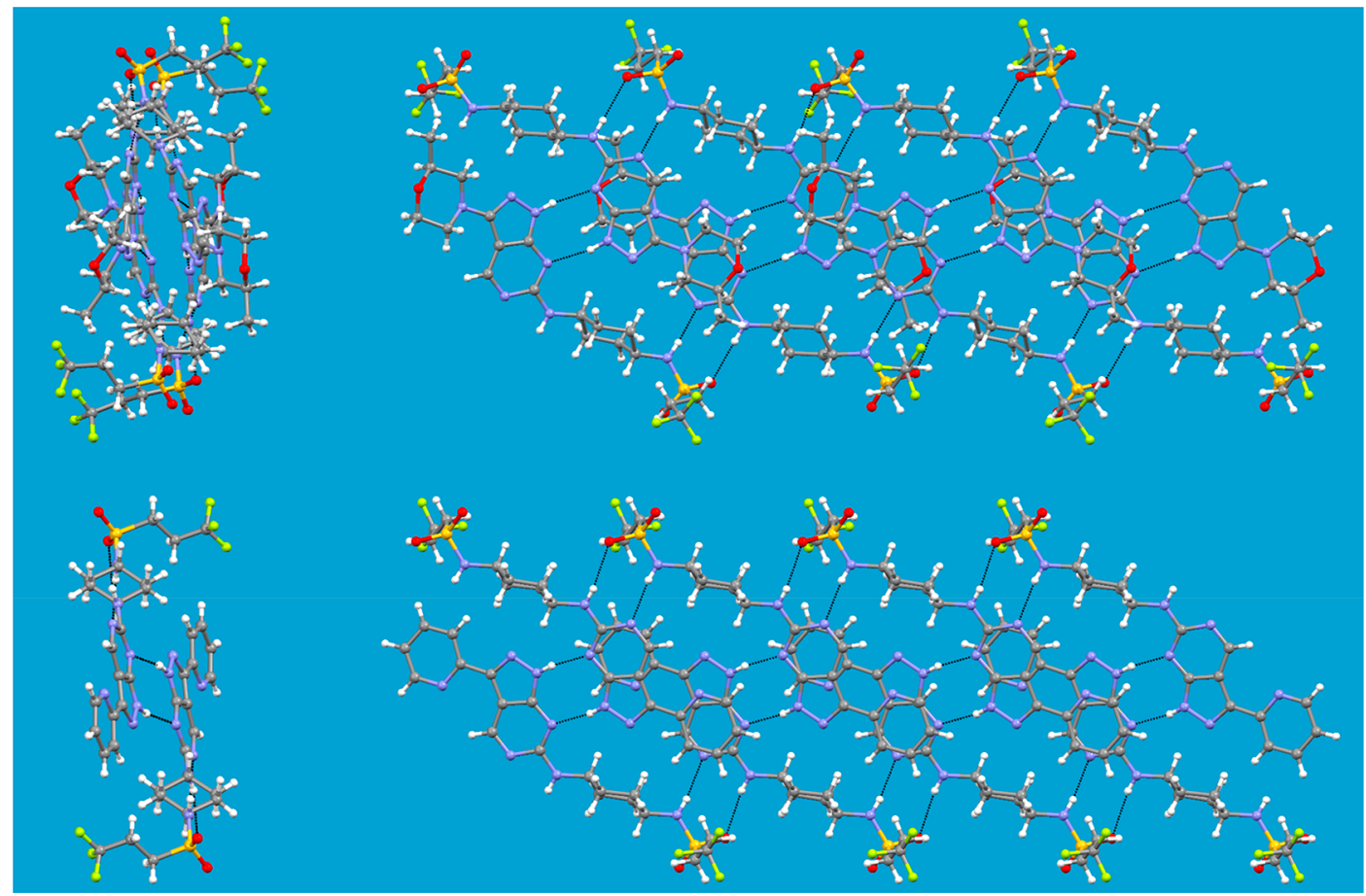

Figure 7. Hydrogen bonded columns in the crystal structures of $\mathbf{1}$ and 15: (a) a view down a column in 1; (b) an orthogonal view to (a); (c) a view down a column in 15; (d) an orthogonal view to (c). Hydrogen bonds are displayed as black dotted lines.

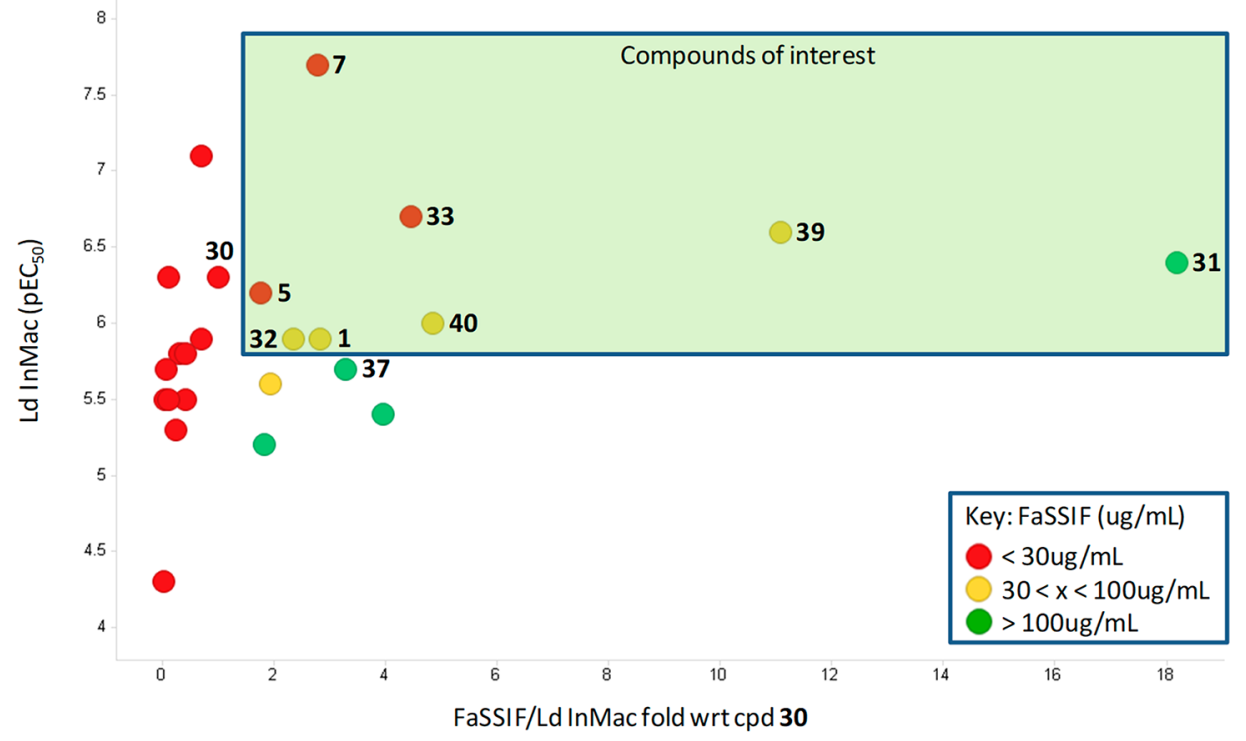

Figure 8. Ld InMac vs FaSSIF/Ld InMac fold wrt cpd 30. Ld InMac is the intramacrophage assay carried out in THP-1 cells with L. donovani amastigotes. ${ }^{14}$ Data are the result of at least three replicates. FaSSIF/EC ${ }_{50}$ fold wrt cpd 30 is the FaSSIF and Ld InMac ratio of a new compound compared to 30 .

the layers in the crystal structure and therefore influence the melting point. Thus, a bulkier sulphonamide, as exemplified by enantiomers 34 and 35, were designed to further exploit this hypothesis (Table 9). Encouragingly, both enantiomers demonstrated an increase in FaSSIF solubility, albeit with a loss of intracellular potency compared to 32 and 33 .

Excited by this result, the alternative LHS that could break planarity and affect the stacking of the crystal structure were prioritized (i.e., 36, 37, 1, and 38). As Table 9 shows, all these compounds demonstrated increased FaSSIF solubility alongside similar or increased in vitro potency compared to $\mathbf{2 1}$. It was postulated that adding OMe to the core and iso-butyl sulphonamide to these examples could further increase in vitro potency while maintaining FaSSIF solubility, as had been seen for 33. Indeed, both examples $\mathbf{3 9}$ and $\mathbf{4 0}$ showed a similar increase in potency (in vitro), although 39 had a lower FaSSIF solubility than expected compared to 40. This observation between enantiomers was also mirrored for $1 / 38$ and $36 / 37$, although the rationale for this is still unclear.

Interestingly, $\mathbf{1}$ crystallized in the noncentrosymmetric space group $(P 1)$ and has four independent molecules in the asymmetric unit (Figure 7 ). Although a different space group 


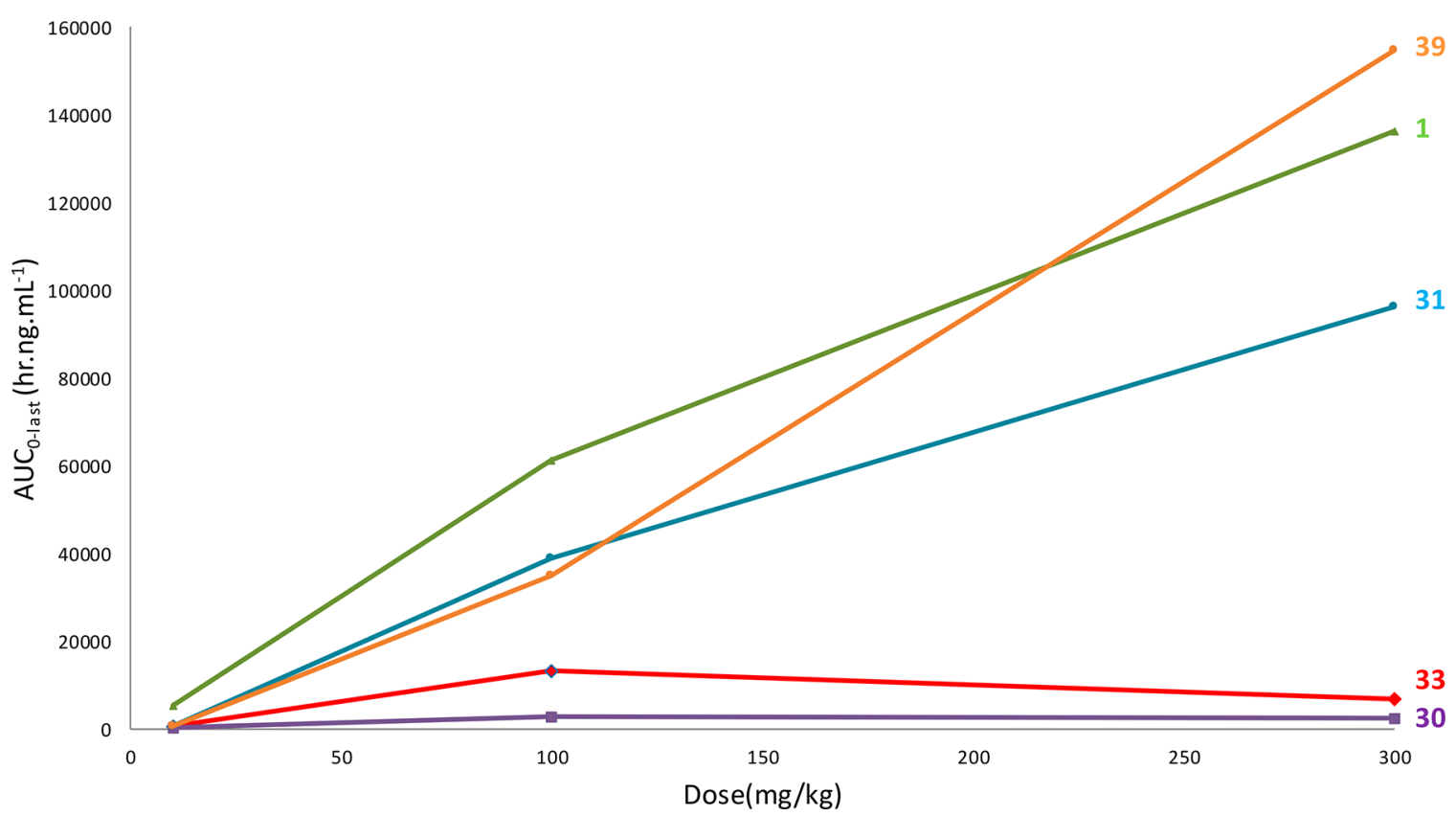

Figure 9. Rat PK dose escalation studies for 30, 31, 33, 1, and 39.

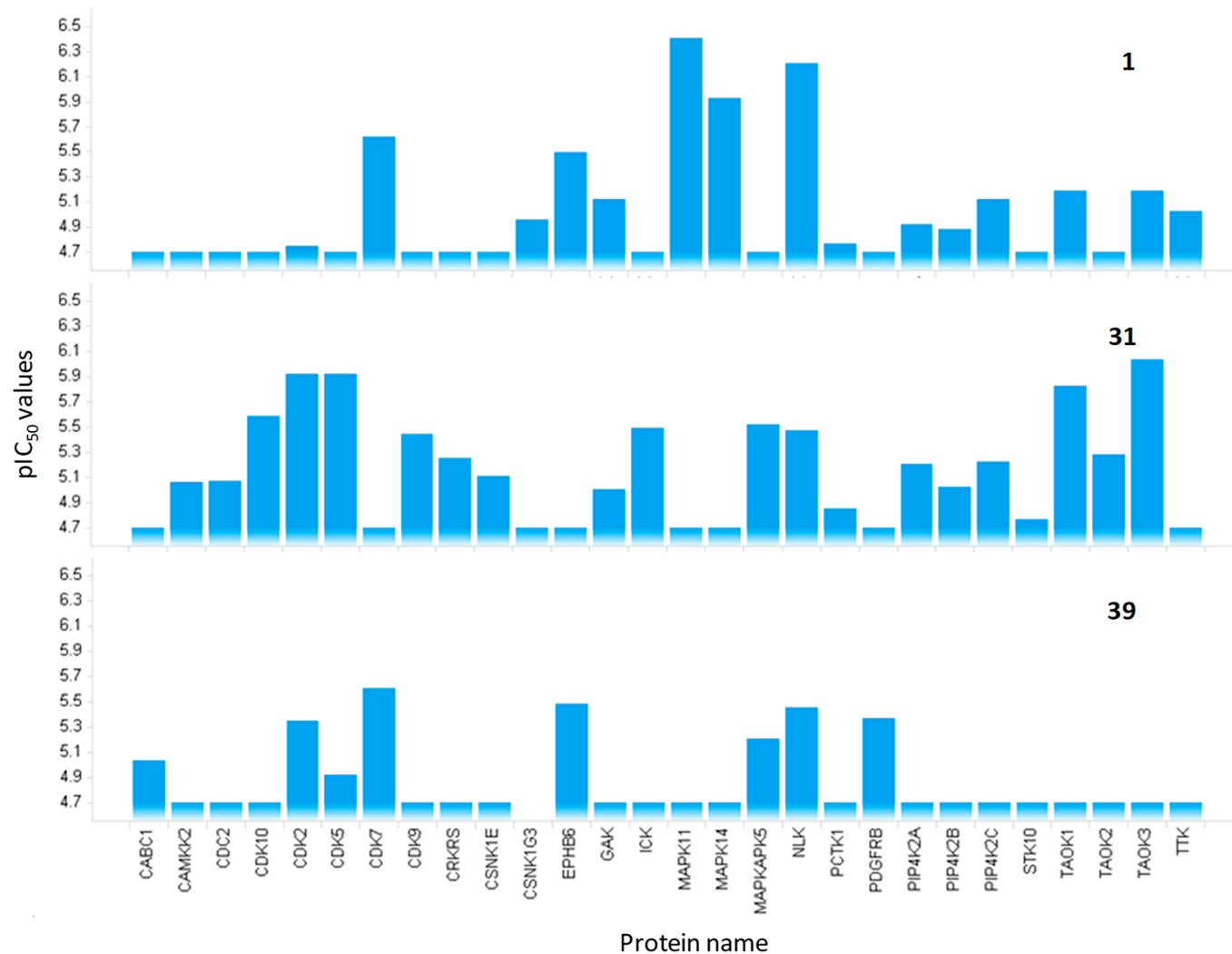

Figure 10. Human kinase selectivity profile of 1,31 , and 39 . The figure shows all human protein kinases affected by any of the three compounds (no bar, protein was not identified; maximum compound concentration analyzed was $20 \mu \mathrm{M}$ ).

to 15 , analogous intermolecular hydrogen bonds were found to exist in 1 and 15, giving rise to columns in the same way. In cross-section, the columns are wider for $\mathbf{1}$ as they must accommodate the substituted morpholinyl groups and the removal of the $\pi-\pi$ stacking. Although the structure of $\mathbf{1}$ has no centers of symmetry owing to the chiral ring, a pseudocentrosymmetric arrangement has been adopted. In effect, the four independent molecules in $\mathbf{1}$ increase the flexibility of the system, allowing the same hydrogen bonds to exist as in $\mathbf{1 5}$ despite the much bulkier, chiral ring being present. Overall, however, the packing in $\mathbf{1}$ is clearly less efficient than $\mathbf{1 5}$, leading to a density of $1.405 \mathrm{gcm}^{-3}$ (versus $1.511 \mathrm{gcm}^{-3}$ ) at the temperature of the experiments $(150 \mathrm{~K})$ and a packing coefficient of 0.676 (versus 0.699 ). In this respect, the deliberate attempt to disrupt the 


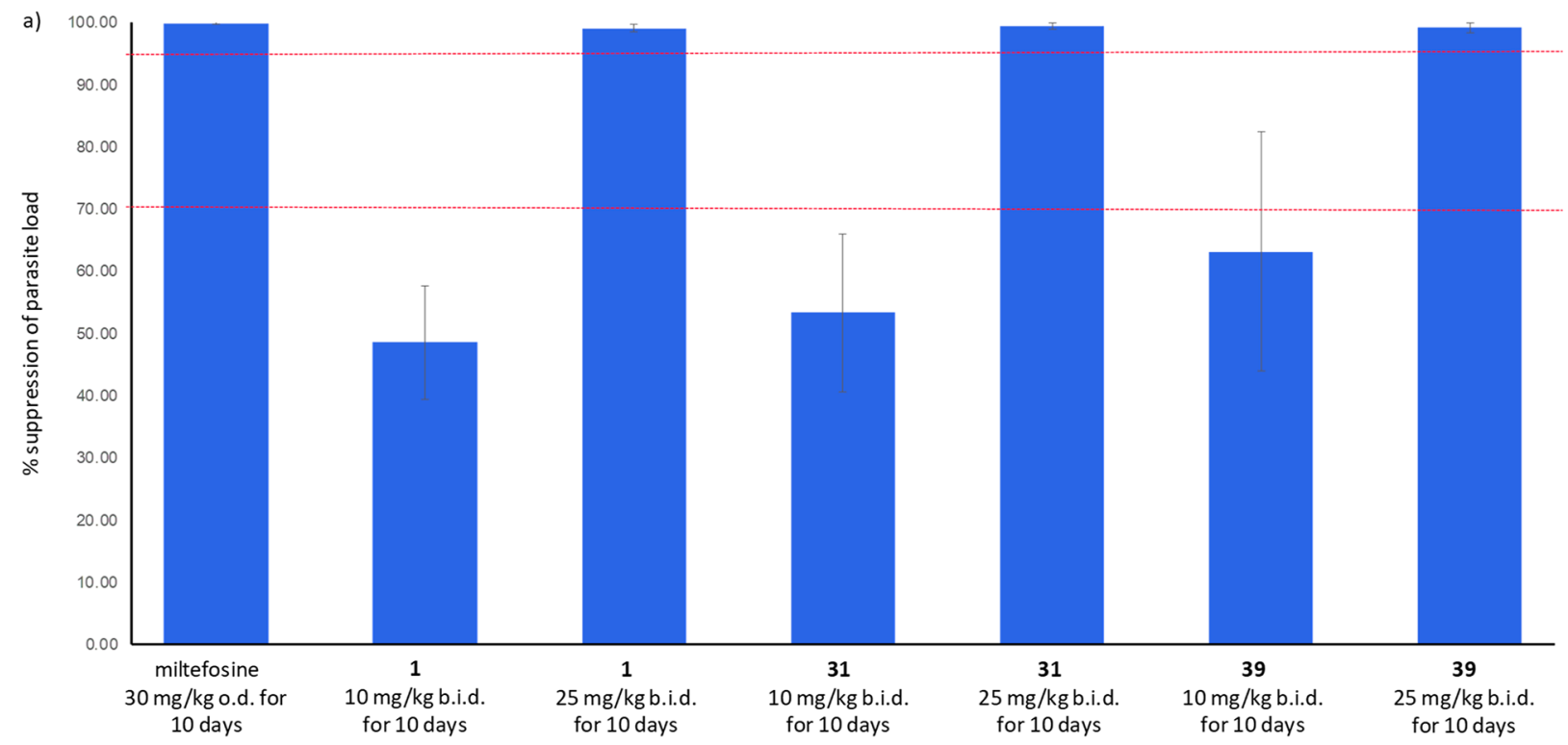

b)

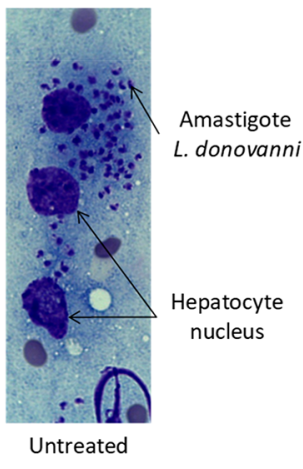

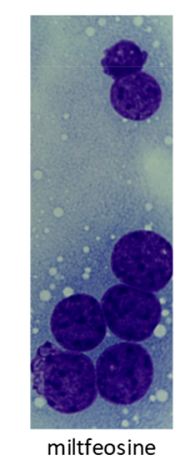

$30 \mathrm{mg} / \mathrm{kg}$ o.d. for 10 days

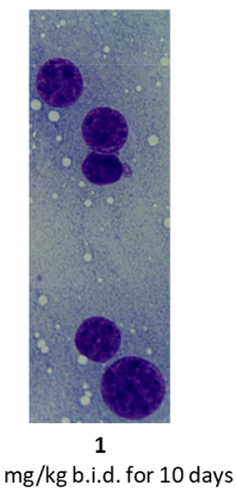

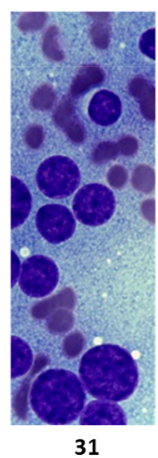

$25 \mathrm{mg} / \mathrm{kg}$ b.i.d. for 10 days

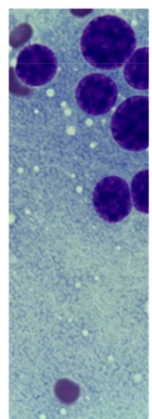

39

$25 \mathrm{mg} / \mathrm{kg}$ b.i.d. for 10 days

Figure 11. (a) In vivo efficacy of 31, 1, and 39 compared to miltefosine; (b) mouse liver smears from in vivo efficacy model for untreated, miltefosine, 31, 1, and 39. The mean LDU values from individual animal livers were compared to the control to give the percentage (\%) suppression of parasite load in Balb/c mice (that were infected with $L$. donovani). Vehicle used for 31 , 1, and 39 was $0.5 \%$ HPMC, $0.4 \%$ Tween 80 , and $0.5 \%$ benzyl alcohol, and deionized water for miltefosine. This experiment was carried out using five mice per dose level. Error bars represent the standard deviation (SD). Lead optimization criteria was $70 \%$ suppression in liver parasite burden, while the preclinical candidate was $>95 \%$.

packing found in $\mathbf{1 5}$ was a success and helped to improve FaSSIF solubility while maintaining in vitro potency (Table 8 and 9).

Upon analyzing the data shown in Table 9, it became clear that there was no correlation between FaSSIF solubility and in vitro potency. Consequently, multiparameter optimization was pursued (eq 2), whereby the FaSSIF and Ld InMac ratio of a new compound was compared to a reference compound (i.e. 30 ), coupled with a potency filter of $\mathrm{Ld} \operatorname{InMac} \mathrm{pEC}_{50} \geq 5.8$, and this allowed more informed compound progression decisions.

FaSSIF/Ld InMac fold wrt cpd 30

$$
=\operatorname{FaSSIF}\left(\frac{\text { new cpd }}{\text { cpd } 30}\right) \times \operatorname{Ld~InMac~EC} \mathrm{E}_{50}\left(\frac{\text { cpd } 30}{\text { new cpd }}\right)
$$

\section{Equation 2: FaSSIF/Ld InMac fold wrt cpd 30.}

The reasoning behind the additional in vitro potency filter was that compounds from this series with $\mathrm{Ld}$ InMac $\mathrm{pEC}_{50}<5.8$ were never seen to demonstrate desirable in vivo efficacy at a further reduced dose (i.e., $\leq 25 \mathrm{mg} / \mathrm{kg}$ b.i.d.), even when having progressable FaSSIF solubility (for example, compound 37 demonstrated $65 \%$ parasite suppression at $25 \mathrm{mg} / \mathrm{kg}$ b.i.d. for 10 days).
Figure 8 highlights the compounds of interest based on the selection criteria discussed above (i.e. 31, 33, 1, and 39), which were subsequently progressed to rat $\mathrm{PK}$ dose escalation studies (Figure 9). Compounds $\mathbf{5}$ and 7 were rejected due to metabolic instability when incubated with mouse liver microsomes (Table 2), whereas 32 and 40 showed no advantage in terms of "FaSSIF/Ld InMac fold wrt cpd 30" profile over their counterparts 33 and 39, respectively (Table 9).

33 was progressed into rat PK on the basis of high potency compensating for low FaSSIF solubility. However, it gave very similar exposures to $\mathbf{3 0}$ upon dose escalation (Figure 9), demonstrating that it was not suitable for further progression. Pleasingly, however, 3 out of the 4 compounds (31, 1, and 39) demonstrated notably superior exposure to $\mathbf{3 0}$ as measured by the AUC (Figure 9), in line with the multiparameter hypothesis. Furthermore, these compounds all showed a dose proportional exposure increase, which would be important in further development of the compound series, particularly when determining potential therapeutic indices.

Chemoproteomic profiling on Kinobeads was performed in a mixed human cell/tissue extract, to identify potential human offtargets for 31, 1, and 39 (Figure 10). The compounds were 
tested for their activity against $>260$ human protein kinases, and $\mathrm{IC}_{50}$ values were generated. Figure 10 shows only kinases affected by any of the three compounds, indicating that the three compounds had different human kinase profiles. Cdk4 was only

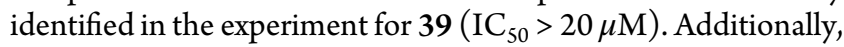
31 and 39 did show potency against Cdk2, albeit 9- or 35-fold less potent respectively than the closest analogue from Ding and co-workers, ${ }^{19}$ where it was unaffected by $\mathbf{1}$. However, the extent of inhibition of these human kinases was not sufficient to preclude progression for any one compound. Interestingly, performing similar dose-response experiments using leishmania parasite lysate for 8 identified CRK12 ( IC $_{50} 3 \mathrm{nM}$ ), MPK9 $\left(\mathrm{IC}_{50} 105-181 \mathrm{nM}\right)$, and CRK6 (IC $\left.50194-363 \mathrm{nM}\right){ }^{17}$

On this basis, 31, 1, and 39 were progressed into in vivo efficacy studies, where all three gave sufficient parasite suppression to be considered as preclinical development candidates at $25 \mathrm{mg} / \mathrm{kg}$ b.i.d. for 10 days (Figure 11). As such, all three compounds were profiled in key in vitro and ex vivo safety assays (Table 10) in order to select a lead compound to prioritize for a 7 day toxicology study.

Table 10. Comparison of three Key Compounds (31, 1, and 39)

\begin{tabular}{|c|c|c|c|}
\hline & 31 & 1 & 39 \\
\hline Ld InMac $\left(\mathrm{pEC}_{50}\right)^{a}$ & 6.4 & 5.9 & 6.6 \\
\hline $\mathrm{Cl}_{\mathrm{i}}\left(\mathrm{mL} \cdot \mathrm{min}^{-1} \cdot \mathrm{g}^{-1}\right)^{b}$ & 1.1 (mouse) & $\begin{array}{r}<0.5 \text { (mouse) } \\
0.7 \text { (human) }\end{array}$ & $\begin{array}{l}0.6 \text { (mouse) } \\
2.5 \text { (human) }\end{array}$ \\
\hline $\begin{array}{l}\text { mouse in vivo efficacy } \\
\text { (>95\% parasite } \\
\text { suppression) }\end{array}$ & $\begin{array}{l}25 \mathrm{mg} / \mathrm{kg} \text { b.i.d. } \\
\text { @ } 10 \mathrm{~d}\end{array}$ & $\begin{array}{l}25 \mathrm{mg} / \mathrm{kg} \text { b.i.d. } \\
\text { (a) } 10 \mathrm{~d}\end{array}$ & $\begin{array}{l}25 \mathrm{mg} / \mathrm{kg} \text { b.i.d. } \\
\text { @ } 10 \mathrm{~d}\end{array}$ \\
\hline $\mathrm{PFI}^{c}$ & 8.0 & 5.5 & 6.1 \\
\hline $\operatorname{FaSSIF}(\mu \mathrm{g} / \mathrm{mL})^{d}$ & 25 & $17^{e}$ & 33 \\
\hline CYP3A4 $\left(\mathrm{pIC}_{50}\right)$ & 5.2 & $<4.4$ & $<4.4$ \\
\hline Ames $^{38}$ & $\begin{array}{c}- \text { ve @ } 1500 \\
\mu \mathrm{g} / \text { plate }\end{array}$ & $\begin{array}{c}- \text { ve @ } 1500 \\
\mu \mathrm{g} / \text { plate }\end{array}$ & $\begin{array}{c}- \text { ve @ } 1500 \\
\mu \mathrm{g} / \text { plate }\end{array}$ \\
\hline $\operatorname{MLA}^{f}$ & $\begin{array}{r}-\mathrm{ve} @ 5 \\
\mu \mathrm{g} / \mathrm{mL}\end{array}$ & $\begin{array}{c}\text {-ve@120 } \\
\mu \mathrm{g} / \mathrm{mL}\end{array}$ & $\begin{array}{l}\text { equivocal@ } \\
350 \mu \mathrm{g} / \mathrm{mL}\end{array}$ \\
\hline hERG $\left(\mathrm{IC}_{50}, \mu \mathrm{M}\right)^{39,40}$ & 17.5 & $>30$ & $>30$ \\
\hline $\mathrm{RVW}^{g}$ & $\begin{array}{l}\text { QT shortening } \\
(11.3 \% @ \\
10 \mu \mathrm{M})\end{array}$ & $\begin{array}{l}\text { QT shortening } \\
(8.9 \% @ \\
30 \mu \mathrm{M})\end{array}$ & $\begin{array}{l}\text { QT shortening } \\
(15.2 \% @ \\
100 \mu \mathrm{M})\end{array}$ \\
\hline
\end{tabular}

${ }^{a} \mathrm{Ld}$ InMac is the intramacrophage assay carried out in THP-1 cells with $L$. donovani amastigotes. ${ }^{14}$ Data are the result of at least six replicates. ${ }^{b} \mathrm{Cl}_{\mathrm{i}}$ is liver microsomal intrinsic clearance. ${ }^{c} \mathrm{PFI}$ is the property forecast index; ${ }^{31}$-ve is negative. ${ }^{d}$ FaSSIF is fasted state simulated intestinal fluid solubility. ${ }^{32} e$ Melting point for this batch was $262{ }^{\circ} \mathrm{C} .{ }^{f} \mathrm{MLA}$ is mouse lymphoma assay. ${ }^{41} g_{\mathrm{RVW}}$ is rabbit ventricular wedge. $^{42}$

Following a form screen, the most stable form was identified and the corresponding FaSSIF solubility is reported in Table 10. Apparent inhibition by $\mathbf{3 1}$ in an in vitro hERG assay ${ }^{39,40}$ prompted progression of all three compounds to the ex vivo rabbit ventricular wedge (RVW) assay. ${ }^{42}$ Interestingly, they all showed a similar effect of QT shortening, which appears to be independent of hERG in vitro potency. The clinical relevance of this QT shortening finding and its translation in vivo was unclear. $^{43}$ There were no changes to the remaining QT parameters tested, and the risk of QT prolongation and Torsade de pointes (TdP) arrhythmia in humans was assessed as low based on these results. Because there were only minor differences, all three compounds were progressed into 7 day rat toxicology and rat cardiovascular studies (Table 11).

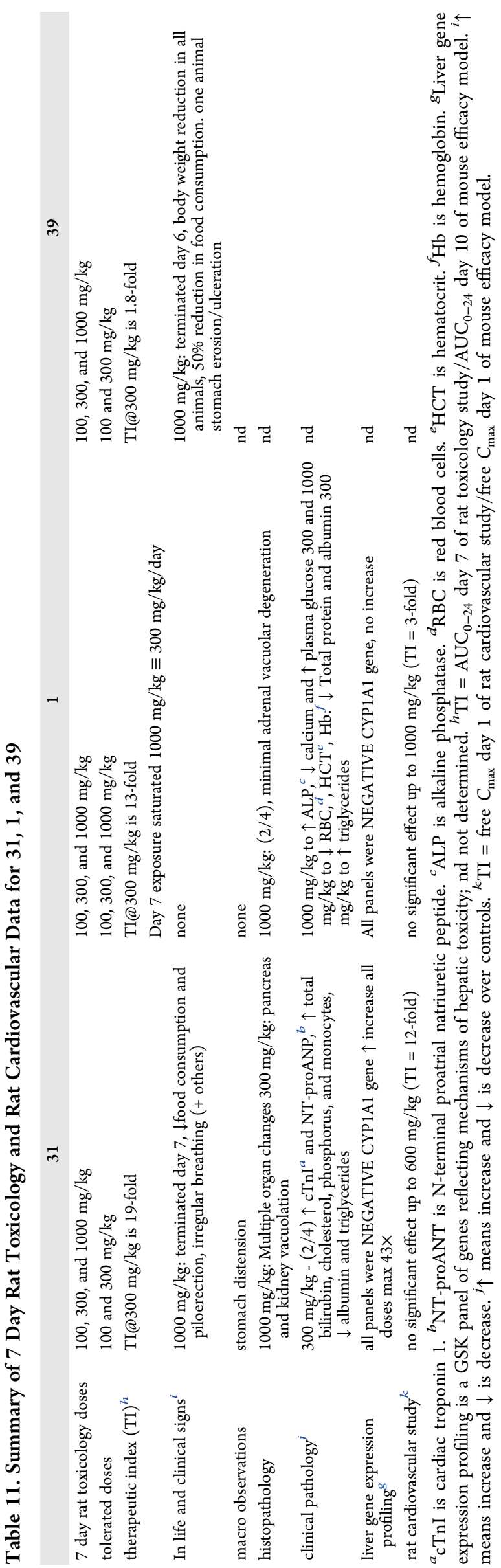


The outcome of the 7 day studies was the deselection of 39 , as the therapeutic index (TI) was not sufficient for progression (Table 11). 1 was selected as the preclinical candidate for VL (as opposed to 31) due to the fact the TI was limited by exposure and not by an adverse event, coupled with no direct inhibition of CYP3A4 and no flags within liver gene expression profiling panel (which can lead to problematic drug-drug interactions that are particularly relevant due to the frequency of VL/HIV coinfections). ${ }^{44}$

\section{SUMMARY AND CONCLUSION}

Initial hit 4 demonstrated a promising profile (Table 1) but highlighted the need to optimize in vitro potency and mouse metabolic stability in order to test this series within an in vivo $\mathrm{VL}$ animal study. With those properties improved and selectivity against a panel of human kinases, $\mathbf{1 5}$ was progressed to such an in vivo model, where it demonstrated an $85 \%$ suppression in parasite load within the liver (Figure 4). However, due to low CLND solubility, $\mathbf{1 5}$ was not progressed further because it required the use of a vehicle that was not acceptable in downstream toxicological studies. Successfully using PFI to improve solubility of this series led to compound 30, which demonstrated candidate quality efficacy using a formulation that could be used for toxicological studies (Table 6). Dose escalation in rats demonstrated that $\mathbf{3 0}$ exhibited variable nonlinear exposure, limiting the ability to assess its therapeutic index in toxicological studies (Table 7). It was speculated that the low FaSSIF solubility was driving this variable nonlinear exposure. After investigating the small molecule crystal structure of 15 (Figure 6), disrupting certain hydrogen bonds and breaking planarity by introducing specific substituents became the primary medicinal chemistry focus. Multiple compounds demonstrated improved FaSSIF solubility, however, the use of a mathematical comparison to $\mathbf{3 0}$ and a potency filter (eq 2 and Figure 8) aided the selection of 31, 33, 1, and 39. All except 33 (where high potency compensated for low FaSSIF solubility) demonstrated superior exposure compared to $\mathbf{3 0}$ (Figure 9). This demonstrated that FaSSIF solubility gave a better correlation to rat PK exposure than CLND for this series, likely due to being more relevant to biological systems and the fact that it is a thermodynamic measurement of solubility. To further differentiate between $\mathbf{3 1}, \mathbf{1}$, and 39 (Table 10), all were progressed into 7 day rat toxicological studies (Table 11). 1 was finally selected as a preclinical candidate for VL, and definitive safety studies are being conducted to support clinical progression. Compound $\mathbf{1}$ is one of only a handful of compounds worldwide that have reached preclinical candidate status for VL, highlighting the need and also the achievement.

\section{EXPERIMENTAL SECTION}

General Experimental Information. Chemicals and solvents were purchased from the Aldrich Chemical Co., Fluka, Fluorochem, ABCR, VWR, Acros, Fisher Chemicals, and Alfa Aesar and were used as received unless otherwise stated. Air- and moisture-sensitive reactions were carried out under an inert atmosphere of argon in oven-dried glassware. Analytical thin-layer chromatography (TLC) was performed on precoated TLC plates (layer $0.20 \mathrm{~mm}$ silica gel 60 with fluorescent indicator UV254, from Merck). Developed plates were air-dried and analyzed under a UV lamp (UV254/365 nm). Flash column chromatography was performed using prepacked silica gel cartridges (230-400 mesh, 40-63 $\mu \mathrm{m}$, from SiliCycle) using a Teledyne ISCO Combiflash Companion, or Combiflash Retrieve. ${ }^{1} \mathrm{H}$ NMR, ${ }^{13} \mathrm{C}$ NMR, ${ }^{19} \mathrm{~F}$ NMR, and 2D-NMR spectra were recorded on a Bruker Avance DPX 500 spectrometer $\left({ }^{1} \mathrm{H}\right.$ at $500.1 \mathrm{MHz},{ }^{13} \mathrm{C}$ at $125.8 \mathrm{MHz},{ }^{19} \mathrm{~F}$ at
$470.5 \mathrm{MHz})$. Chemical shifts $(\delta)$ are expressed in ppm recorded using the residual solvent as the internal reference in all cases. Signal splitting patterns are described as singlet $(\mathrm{s})$, doublet $(\mathrm{d})$, triplet $(\mathrm{t})$, quartet $(\mathrm{q})$, multiplet $(\mathrm{m})$, broad $(\mathrm{b})$, or a combination thereof. Coupling constants $(J)$ are quoted to the nearest $0.1 \mathrm{~Hz}$. LC-MS analyses were performed with either an Agilent HPLC 1100 series connected to a Bruker Daltonics MicrOTOF or an Agilent Technologies 1200 series HPLC connected to an Agilent Technologies 6130 quadrupole LC/MS, where both instruments were connected to an Agilent diode array detector. Mobile phase was water/acetonitrile $+0.1 \% \mathrm{HCOOH}$, or water/ acetonitrile $+0.1 \% \mathrm{NH}_{3}$; linear gradient $80: 20$ to $5: 95$ over $3.5 \mathrm{~min}$, and then held for $1.5 \mathrm{~min}$; flow rate $0.5 \mathrm{~mL} \mathrm{~min}^{-1}$. All intermediates had a measured purity of $>90 \%$ as determined using this analytical LC-MS system unless otherwise noted. All assay compounds had a measured purity of $\geq 95 \%$ as determined using this analytical LC-MS system (TIC and UV). High resolution electrospray measurements were performed on a Bruker Daltonics MicrOTOF mass spectrometer. Microwaveassisted chemistry was performed using a Biotage Initiator microwave synthesizer.

3,3,3-Trifluoro- $N$-(trans-4-((3-((S)-2-methylmorpholino)- $1 \mathrm{H}$ pyrazolo[3,4-d]pyrimidin-6-yl)amino)cyclohexyl)propane-1-sulfonamide 1. 29a (91 g, $173 \mathrm{mmol})$ was dissolved in dioxane $(1.2 \mathrm{~L})$, then hydrazine hydrate $85 \%(173.2 \mathrm{~g}, 3.5 \mathrm{~mol})$ was added and the reaction stirred at $90^{\circ} \mathrm{C}$ for $18 \mathrm{~h}$. The mixture was cooled to $25^{\circ} \mathrm{C}$, where $\mathrm{H}_{2} \mathrm{O}$ $(800 \mathrm{~mL})$ and EtOAc $(800 \mathrm{~mL})$ was added and the mixture was stirred at room temperature for $20 \mathrm{~min}$. The organic phase was separated, and the aqueous phase was extracted with EtOAc $(3 \times 1.5 \mathrm{~L})$. The combined organic phases were washed with brine $(2 \times 2 \mathrm{~L})$ and dried over $\mathrm{Na}_{2} \mathrm{SO}_{4}$. The solvent was removed under vacuum, and EtOAc $(400 \mathrm{~mL})$ was added to the residue and stirred at room temperature for $1 \mathrm{~h}$. The resulting mixture was filtered, the cake was washed with EtOAc $(100 \mathrm{~mL})$, and the filtrate was dried in vacuo to afford a crude solid. This solid was then purified by recrystallization from methanol (400 $\mathrm{mL})$ to give 1 ( $40 \mathrm{~g}, 81 \mathrm{mmol}, 47 \%$ yield) as a light-green solid. ${ }^{1} \mathrm{H}$ NMR (DMSO- $\left.d_{6}\right): \delta 11.93(\mathrm{~s}, 1 \mathrm{H}), 8.82(\mathrm{~s}, 1 \mathrm{H}), 7.33(\mathrm{~d}, J=7.6 \mathrm{~Hz}$, $1 \mathrm{H}), 7.14(\mathrm{~s}, 1 \mathrm{H}), 3.86(\mathrm{dd}, J=10.9$ and $2.9 \mathrm{~Hz}, 1 \mathrm{H}), 3.73-3.55(\mathrm{~m}$, $5 \mathrm{H}), 3.31-3.09(\mathrm{~m}, 3 \mathrm{H}), 2.90-2.81(\mathrm{~m}, 1 \mathrm{H}), 2.66-2.50(\mathrm{~m}, 3 \mathrm{H}), 1.92$ (br s, $4 \mathrm{H}), 1.39-1.29(\mathrm{~m}, 4 \mathrm{H}), 1.15(\mathrm{~d}, J=6.2 \mathrm{~Hz}, 3 \mathrm{H}) .{ }^{13} \mathrm{C}$ NMR $\left(\right.$ DMSO- $\left.d_{6}\right): \delta 160.5,157.3,154.0,151.3,127.9\left(\mathrm{q}, J_{\mathrm{CF}}=128 \mathrm{~Hz}\right), 71.3$, 65.9, 54.6, 52.0, 49.9, 47.9, 45.4, 33.1 (2C), $31.2(2 \mathrm{C}), 28.9\left(\mathrm{q}, J_{\mathrm{CF}}=\right.$ $29.9 \mathrm{~Hz}$ ), 19.2. ${ }^{19} \mathrm{~F}$ NMR (DMSO- $\left.d_{6}\right) \delta-64.4$. HRMS $\left(\mathrm{ES}^{+}\right): m / z[\mathrm{M}$ $+\mathrm{H}]^{+}$calcd for $\mathrm{C}_{19} \mathrm{H}_{29} \mathrm{~N}_{7} \mathrm{O}_{3} \mathrm{~F}_{3} \mathrm{~S}$ 492.1999, found 492.1998. Enantiopurity determined using a chiral column: Chiralpak AD-3, 3 $\mathrm{mm}, 0.46 \mathrm{~cm} \times 10 \mathrm{~cm}$, acetonitrile $/ \mathrm{MeOH}=50 / 50+0.2 \%$ isopropyl amine, $30 \mathrm{~mL} / \mathrm{min}, 298 \mathrm{~K}, 254 \mathrm{~nm}$. First enantiomer (compound 38, minor) $R_{\mathrm{t}}=6.6 \mathrm{~min}$, second enantiomer $(1$, major $) R_{\mathrm{t}}=9.7 \mathrm{~min} . e e$ measured: $99.2 \%$.

$\mathrm{N}$-Cyclohexyl-3-isobutyl-1H-pyrazolo[3,4-d]pyrimidin-6-amine 3. A mixture of 11 a (100 mg, $0.44 \mathrm{mmol}$ ) and cyclohexylamine ( $48 \mathrm{mg}$, $0.48 \mathrm{mmol})$ in $n$-butanol $(4 \mathrm{~mL})$ was stirred at $100^{\circ} \mathrm{C}$ for $15 \mathrm{~min}$ then cooled to room temperature. Hydrazine hydrate $(360 \mu \mathrm{L}, 1.76 \mathrm{mmol})$ was added and the mixture stirred in a sealed tube at $150{ }^{\circ} \mathrm{C}$ for $45 \mathrm{~min}$ (microwave). The solution was cooled, solvent evaporated, and the crude mixture chromatographed $(0-10 \%$ methanol/DCM) to give 3 $(64 \mathrm{mg}, 0.23 \mathrm{mmol}, 53 \%$ yield $) .{ }^{1} \mathrm{H}$ NMR (DMSO- $\left.d_{6}\right): \delta 12.57(\mathrm{~s}, 1 \mathrm{H})$, $8.74(\mathrm{~s}, 1 \mathrm{H}), 7.12(\mathrm{bs}, 1 \mathrm{H}), 3.72(\mathrm{bs}, 1 \mathrm{H}), 2.64(\mathrm{~d}, J=7.2 \mathrm{~Hz}, 2 \mathrm{H}), 2.05$ (sept., $J=6.9 \mathrm{~Hz}, 1 \mathrm{H}), 1.93-1.89(\mathrm{~m}, 2 \mathrm{H}), 1.77-1.71(\mathrm{~m}, 2 \mathrm{H}), 1.64-$ $1.58(\mathrm{~m}, 1 \mathrm{H}), 1.35-1.13(\mathrm{~m}, 5 \mathrm{H}), 0.91(\mathrm{~d}, J=6.6 \mathrm{~Hz}, 6 \mathrm{H}) .{ }^{13} \mathrm{C}$ NMR $\left(\right.$ DMSO- $\left.d_{6}\right): \delta 160.6,157.5,153.6,145.7,106.7,49.6,36.5,32.7,28.6$ (2C), 25.9 (2C), $25.4(2 \mathrm{C}), 22.9$. HRMS $\left(\mathrm{ES}^{+}\right): m / z[\mathrm{M}+\mathrm{H}]^{+}$calcd for $\mathrm{C}_{15} \mathrm{H}_{24} \mathrm{~N}_{5} 274.2032$, found 274.2018.

$\mathrm{N}$-(trans-4-((3-Isobutyl-1H-pyrazolo[3,4-d]pyrimidin-6-yl)amino)cyclohexyl)-2-methylpropane-1-sulfonamide 6 . 6 was obtained by an analogous method to $3\left(28 \mathrm{mg}, 0.07 \mathrm{mmol}, 44 \%\right.$ yield). ${ }^{1} \mathrm{H}$ NMR (DMSO- $\left.d_{6}\right): \delta 12.50(\mathrm{bs}, 1 \mathrm{H}), 8.65(\mathrm{~s}, 1 \mathrm{H}), 7.14(\mathrm{~s}, 1 \mathrm{H}), 6.94$ $(\mathrm{d}, J=7.6 \mathrm{~Hz}, 1 \mathrm{H}), 3.03-2.88(\mathrm{~m}, 2 \mathrm{H}), 2.81(\mathrm{~d}, J=6.3 \mathrm{~Hz}, 2 \mathrm{H}), 2.55$ $(\mathrm{d}, J=7.1 \mathrm{~Hz}, 2 \mathrm{H}), 2.03-1.91(\mathrm{~m}, 2 \mathrm{H}), 1.87-1.79(\mathrm{~m}, 4 \mathrm{H}), 1.27-1.21$ $(\mathrm{m}, 4 \mathrm{H}), 0.93(\mathrm{~d}, J=6.8 \mathrm{~Hz}, 6 \mathrm{H}), 0.81(\mathrm{~d}, J=6.6 \mathrm{~Hz}, 6 \mathrm{H})$. HRMS $\left(\mathrm{ES}^{+}\right): m / z[\mathrm{M}+\mathrm{H}]^{+}$calcd for $\mathrm{C}_{19} \mathrm{H}_{33} \mathrm{~N}_{6} \mathrm{O}_{2} \mathrm{~S}$ 409.2386, found 409.2400 . 
3,3,3-Trifluoro-N-(trans-4-((3-isobutyl-1H-pyrazolo[3,4-d]pyrimidin-6-yl)amino)(yclohexyl)propane-1-sulfonamide 7. 7 was obtained by an analogous method to 3 ( $18 \mathrm{mg}, 0.04 \mathrm{mmol}, 25 \%$ yield). ${ }^{1} \mathrm{H}$ NMR (DMSO- $\left.d_{6}\right): \delta 12.67(\mathrm{~s}, 1 \mathrm{H}), 8.82(\mathrm{~s}, 1 \mathrm{H}), 7.37(\mathrm{~d}, J=7.6 \mathrm{~Hz}$, $1 \mathrm{H}), 7.25(\mathrm{~s}, 1 \mathrm{H}), 3.63(\mathrm{~s}, 1 \mathrm{H}), 3.32-3.27(\mathrm{~m}, 2 \mathrm{H}), 3.16(\mathrm{~s}, 1 \mathrm{H})$, $2.68-2.61(\mathrm{~m}, 4 \mathrm{H}), 2.08-2.00(\mathrm{~m}, 1 \mathrm{H}), 2.08-2.00(\mathrm{~m}, 4 \mathrm{H}), 1.38-$ $1.28(\mathrm{~m}, 4 \mathrm{H}), 0.91(\mathrm{~d}, J=6.5 \mathrm{~Hz}, 6 \mathrm{H})$. HRMS $\left(\mathrm{ES}^{+}\right): m / z[\mathrm{M}+\mathrm{H}]^{+}$ calcd for $\mathrm{C}_{18} \mathrm{H}_{28} \mathrm{~F}_{3} \mathrm{~N}_{6} \mathrm{O}_{2} \mathrm{~S} 449.1947$, found 449.1952 .

$\mathrm{N}$-(trans-4-((3-(2-Methoxyphenyl)-1H-pyrazolo[3,4-d]pyrimidin6-yl)amino)cyclohexyl)-2-methylpropane-1-sulfonamide 8. 8 was obtained by an analogous method to $3(270 \mathrm{mg}, 0.59 \mathrm{mmol}, 72 \%$ yield $)$. ${ }^{1} \mathrm{H}$ NMR (DMSO- $\left.d_{6}\right): \delta 13.08(\mathrm{~s}, 1 \mathrm{H}), 8.76(\mathrm{~s}, 1 \mathrm{H}), 7.66(\mathrm{dd}, J=1.7$, $7.6 \mathrm{~Hz}, 1 \mathrm{H}), 7.47-7.42(\mathrm{~m}, 1 \mathrm{H}), 7.27-7.17(\mathrm{~m}, 2 \mathrm{H}), 7.09-7.00(\mathrm{~m}$, $2 \mathrm{H}), 3.87(\mathrm{~s}, 3 \mathrm{H}), 3.75-3.65(\mathrm{~m}, 1 \mathrm{H}), 3.15-3.08(\mathrm{~m}, 1 \mathrm{H}), 2.91(\mathrm{~d}, J=$ $6.6 \mathrm{~Hz}, 2 \mathrm{H}), 2.17-2.07(\mathrm{~m}, 1 \mathrm{H}), 2.02-1.91(\mathrm{~m}, 4 \mathrm{H}), 1.44-1.35(\mathrm{~m}$, $4 \mathrm{H}), 1.04$ (d, $J=6.6 \mathrm{~Hz}, 6 \mathrm{H}) .{ }^{13} \mathrm{C}$ NMR (DMSO-d $)_{6}$ ): 160.5, 157.6, $155.7,142.3,130.5,130.3,122.1,121.1,112.1,60.4,55.8,51.9,49.1$, 33.3 (2C), 31.2 (2C), 25.0, 22.8 (2C). HRMS $\left(\mathrm{ES}^{+}\right): m / z[\mathrm{M}+\mathrm{H}]^{+}$ calcd for $\mathrm{C}_{22} \mathrm{H}_{31} \mathrm{~N}_{6} \mathrm{O}_{3} \mathrm{~S} 459.2178$, found 459.2183 .

2-Methyl-N-(trans-4-((3-(pyridin-2-yl)-1H-pyrazolo[3,4-d]pyrimidin-6-yl)amino)cyclohexyl)propane-1-sulfonamide 9. 9 was obtained by an analogous method to $3(630 \mathrm{mg}, 1.5 \mathrm{mmol}, 59 \%$ yield). ${ }^{1} \mathrm{H}$ NMR (DMSO- $\left.d_{6}\right): \delta 13.32(\mathrm{bs}, 1 \mathrm{H}), 9.34(\mathrm{~s}, 1 \mathrm{H}), 8.71(\mathrm{~d}, J=4.2$ $\mathrm{Hz}, 1 \mathrm{H}), 8.08(\mathrm{~d}, J=8.0 \mathrm{~Hz}, 1 \mathrm{H}), 7.93-7.89(\mathrm{~m}, 1 \mathrm{H}), 7.45(\mathrm{bs}, 1 \mathrm{H})$, $7.49-7.39(\mathrm{~m}, 1 \mathrm{H}), 7.04(\mathrm{~d}, J=6.0 \mathrm{~Hz}, 1 \mathrm{H}), 3.81-3.61(\mathrm{~m}, 1 \mathrm{H})$, $3.12-3.06(\mathrm{~m}, 1 \mathrm{H}), 2.92(\mathrm{~d}, J=6.4 \mathrm{~Hz}, 2 \mathrm{H}), 2.13-2.05(\mathrm{~m}, 1 \mathrm{H})$, $1.97-1.94(\mathrm{~m}, 4 \mathrm{H}), 1.41-1.31(\mathrm{~m}, 4 \mathrm{H}), 1.04(\mathrm{~d}, J=6.7 \mathrm{~Hz}, 6 \mathrm{H}) .{ }^{13} \mathrm{C}$ NMR (DMSO- $\left.d_{6}\right): \delta 160.8,158.2,156.0,159.9,152.7,150.0,144.3$, 137.4, 123.7, 120.1, 60.5, 51.9, 49.1, 33.3 (2C), 31.2 (2C), 25.0, 22.8. HRMS $\left(\right.$ ES $\left.^{+}\right): m / z[\mathrm{M}+\mathrm{H}]^{+}$calcd for $\mathrm{C}_{20} \mathrm{H}_{28} \mathrm{~N}_{7} \mathrm{O}_{2} \mathrm{~S} 430.2020$, found 430.2024 .

$\mathrm{N}$-(trans-4-Aminocyclohexyl)-2-methylpropane-1-sulfonamide 10a. To a solution of tert-butyl $N$-(4-aminocyclohexyl)carbamate (24 g, $112 \mathrm{mmol})$ in THF $(800 \mathrm{~mL})$ at $-78{ }^{\circ} \mathrm{C}$ was added $n$-butyl lithium (2.5 M in hexanes, $49.3 \mathrm{~mL}, 123 \mathrm{mmol}$ ) dropwise and stirred for $20 \mathrm{~min}$ at $-78{ }^{\circ} \mathrm{C}$. The solution was warmed to $-20^{\circ} \mathrm{C}$ and stirred for $15 \mathrm{~min}$, then cooled to $-78{ }^{\circ} \mathrm{C}$. 3,3,3-Trifluoropropane-1-sulfonyl chloride $(15.4 \mathrm{~mL}, 118 \mathrm{mmol})$ was added dropwise, stirred for a further $5 \mathrm{~min}$ at $-78^{\circ} \mathrm{C}$, and then warmed to room temperature where it was stirred for $1 \mathrm{~h}$. The reaction mixture was quenched with $1 \mathrm{M} \mathrm{HCl}(50 \mathrm{~mL})$ and EtOAc $(500 \mathrm{~mL})$, and the aqueous layer separated and extracted with EtOAc $(2 \times 500 \mathrm{~mL})$. The combined organic layers were dried with $\mathrm{Na}_{2} \mathrm{SO}_{4}$ and filtered, and the remaining solvent was evaporated to give a white solid (33.5 g). This crude material $(33.5 \mathrm{~g})$ was dissolved in DCM $(400 \mathrm{~mL})$, and TFA $(38.3 \mathrm{~mL})$ added at room temperature and stirred overnight. The solvent was removed under vacuum to give an oil, and $\mathrm{Et}_{2} \mathrm{O}(70 \mathrm{~mL})$ was added to precipitate $10 \mathrm{a}$ as a white solid $(35 \mathrm{~g}, 100$ mmol, $89 \%$ yield over two steps). ${ }^{1} \mathrm{H}$ NMR (DMSO- $\left.d_{6}\right): \delta 7.97$ (br s, $2 \mathrm{H}), 7.15(\mathrm{~d}, J=7.3 \mathrm{~Hz}, 1 \mathrm{H}), 3.02-2.96(\mathrm{~m}, 1 \mathrm{H}), 2.86(\mathrm{~d}, J=6.5 \mathrm{~Hz}$, $2 \mathrm{H}), 2.46(\mathrm{ddd}, J=3.7,7.2,14.5 \mathrm{~Hz}, 1 \mathrm{H}), 2.09-2.02(\mathrm{~m}, 1 \mathrm{H}), 1.81(\mathrm{t}, J$ $=5.4 \mathrm{~Hz}, 2 \mathrm{H}), 1.75-1.69(\mathrm{~m}, 2 \mathrm{H}), 1.27-1.16(\mathrm{~m}, 2 \mathrm{H}), 1.11-1.03(\mathrm{~m}$, $2 \mathrm{H}), 1.00(\mathrm{~d}, J=6.8 \mathrm{~Hz}, 6 \mathrm{H})$.

$\mathrm{N}$-(trans-4-Aminocyclohexyl)-3,3,3-trifluoropropane-1-sulfonamide 10b. This reaction was performed in two batches. To a suspension of tert-butyl ((1,4-trans)-4-aminocyclohexyl)carbamate (30 $\mathrm{g}, 140 \mathrm{mmol})$ in THF $(1.33 \mathrm{~L})$, cooled at $-78{ }^{\circ} \mathrm{C}$, $n$-butyl lithium (56 $\mathrm{mL}, 140 \mathrm{mmol}$ ) was added dropwise. The resulting mixture was stirred at $-78{ }^{\circ} \mathrm{C}$ for $20 \mathrm{~min}$ and at $-10{ }^{\circ} \mathrm{C}$ for $10 \mathrm{~min}$. After cooling to -78 ${ }^{\circ} \mathrm{C}, 3,3,3$-trifluoropropane-1-sulfonyl chloride (17.64 mL, $140 \mathrm{mmol}$,) was added. After stirring for $1.5 \mathrm{~h}$, it was allowed to warm to RT and stirred for $20 \mathrm{~min}$. The reaction mixture was diluted with $\mathrm{H}_{2} \mathrm{O}(500$ $\mathrm{mL})$, followed by addition of $2 \mathrm{M} \mathrm{HCl}(20 \mathrm{~mL})$ and was extracted with EtOAc $(400 \mathrm{~mL})$. The organic layer was dried over $\mathrm{Na}_{2} \mathrm{SO}_{4}$, filtered, and concentrated to give tert-butyl ((1,4-trans)-4-(3,3,3trifluoropropylsulfonamido)cyclohexyl)carbamate as a white solid $\left(43.5 \mathrm{~g}, 116 \mathrm{mmol}, 83 \%\right.$ yield). ${ }^{1} \mathrm{H}$ NMR (DMSO- $\left.d_{6}\right): \delta 7.33$ (d, $J=$ $6.4 \mathrm{~Hz}, 1 \mathrm{H}), 6.77-6.70(\mathrm{~d}, J=6.7 \mathrm{~Hz}, 1 \mathrm{H}), 3.30-3.23(\mathrm{~m}, 2 \mathrm{H}), 3.17-$ $3.01(\mathrm{~m}, 2 \mathrm{H}), 2.70-2.56(\mathrm{~m}, 2 \mathrm{H}), 1.87-1.67(\mathrm{~m}, 4 \mathrm{H}), 1.36(\mathrm{~s}, 9 \mathrm{H})$, 1.31-1.13 (m, 4H). TFA $(182 \mathrm{~mL}, 2377 \mathrm{mmol})$ was added to a solution of tert-butyl ((1,4-trans)-4-(3,3,3-trifluoropropylsulfon- amido)cyclohexyl)carbamate (89 g, $238 \mathrm{mmol})$ in DCM $(732 \mathrm{~mL})$, cooled to $0{ }^{\circ} \mathrm{C}$. The reaction mixture was stirred at RT overnight. The mixture was concentrated to dryness and coevaporated with $\mathrm{Et}_{2} \mathrm{O}$ (100 $\mathrm{mL}$ ) to give $\mathbf{1 0 b}$ as a white solid (93.5 g, $238 \mathrm{mmol}$, quant yield). ${ }^{1} \mathrm{H}$ NMR (DMSO- $\left.d_{6}\right): \delta 7.89$ (br s, $\left.2 \mathrm{H}\right), 7.43(\mathrm{~d}, J=7.5 \mathrm{~Hz}, 1 \mathrm{H}), 3.34-$ $3.24(\mathrm{~m}, 2 \mathrm{H}), 3.16-3.05(\mathrm{~m}, 1 \mathrm{H}), 2.99-2.86(\mathrm{~m}, 1 \mathrm{H}), 2.72-2.56(\mathrm{~m}$, $2 \mathrm{H}), 1.95-1.84(\mathrm{~m}, 4 \mathrm{H}), 1.43-1.21(\mathrm{~m}, 4 \mathrm{H})$.

1-(2-Chloro-4-methoxypyrimidin-5-yl)-3-methylbutan-1-one 11a. To a solution of 5-bromo-2-chloro-4-methoxypyrimidine $(1.11 \mathrm{~g}$, $5 \mathrm{mmol})$ in THF $(20 \mathrm{~mL})$ at $-40^{\circ} \mathrm{C}$ was added a solution of iso-propyl magnesium chloride ( $3 \mathrm{~mL}, 6.5 \mathrm{mmol}, 2 \mathrm{M}$ in ether) dropwise over 10 $\mathrm{min}$ and the resulting suspension stirred for $15 \mathrm{~min}$. A solution of isovaleraldehyde $(700 \mu \mathrm{L}, 6.5 \mathrm{mmol})$ in THF $(2 \mathrm{~mL})$ was added dropwise over $10 \mathrm{~min}$, stirring continued for $30 \mathrm{~min}$ and the reaction quenched with methanol ( $1 \mathrm{~mL})$, allowed to warm to room temperature, and the solvent evaporated. Crude material was taken up in DCM $(20 \mathrm{~mL})$, washed with $2 \mathrm{M} \mathrm{HCl}(20 \mathrm{~mL})$, dried, and evaporated. Crude material was dissolved in DCM $(20 \mathrm{~mL})$, Dess-Martin periodinane $(2.97 \mathrm{~g}, 7$ $\mathrm{mmol}$ ) added, and the reaction mixture stirred for $1 \mathrm{~h}$. A mixture of satd sodium bicarbonate $(20 \mathrm{~mL}) /$ satd sodium thiosulfate $(20 \mathrm{~mL})$ was added and stirring continued for $30 \mathrm{~min}$. The organic layer was separated, dried, evaporated, and crude material chromatographed (0$40 \% \mathrm{EtOAc} /$ heptane $)$ to yield 11 a $(0.65 \mathrm{~g}, 2.9 \mathrm{mmol}, 57 \%$ yield over 2 steps). ${ }^{1} \mathrm{H}$ NMR (DMSO- $\left.d_{6}\right): \delta 8.84(\mathrm{~s}, 1 \mathrm{H}), 4.24(\mathrm{~s}, 3 \mathrm{H}), 2.90(\mathrm{~d}, J=$ $6.8 \mathrm{~Hz}, 2 \mathrm{H}), 2.34-2.27(\mathrm{~m}, 1 \mathrm{H}), 1.06(\mathrm{~d}, J=6.6 \mathrm{~Hz}, 6 \mathrm{H}) . \mathrm{MS}\left(\mathrm{ES}^{+}\right) \mathrm{m} /$ $z$ 229.1, 231.1 $[\mathrm{M}+\mathrm{H}]^{+}$.

3,3,3-Trifluoro-N-(trans-4-((3-(pyridin-2-yl)-1H-pyrazolo[3,4-d]pyrimidin-6-yl)amino)cyclohexyl)propane-1-sulfonamide 15 . 11c (1.25 g, $5 \mathrm{mmol}), 10 \mathrm{~b}(1.50 \mathrm{~g}, 5.5 \mathrm{mmol})$, and DIPEA $(1.05 \mathrm{~mL}, 6$ mmol) in ethanol $(20 \mathrm{~mL})$ were stirred at $120{ }^{\circ} \mathrm{C}$ for $30 \mathrm{~min}$ (microwave). After cooling to room temperature, hydrazine hydrate $(1.1 \mathrm{~mL}, 20 \mathrm{mmol})$ was added and the mixture stirred at $150^{\circ} \mathrm{C}$ for 30 min (microwave). Upon cooling, a precipitate formed, which was collected, washed with ethanol, and dried in vacuo to give $15(1.67 \mathrm{~g}$, $3.6 \mathrm{mmol}, 71 \%$ yield). ${ }^{1} \mathrm{H}$ NMR (DMSO- $\left.d_{6}\right): \delta 13.29(\mathrm{~s}, 1 \mathrm{H}), 9.34(\mathrm{~s}$, $1 \mathrm{H}), 8.71(\mathrm{~d}, J=4.1 \mathrm{~Hz}, 1 \mathrm{H}), 8.09(\mathrm{~d}, J=7.9 \mathrm{~Hz}, 1 \mathrm{H}), 7.91(\mathrm{ddd}, J=$ $7.8,7.8,1.8 \mathrm{~Hz}, 1 \mathrm{H}), 7.51(\mathrm{~s}, 1 \mathrm{H}), 7.43-7.37(\mathrm{~m}, 2 \mathrm{H}), 3.71-3.67(\mathrm{~m}$, $1 \mathrm{H}), 3.34-3.29(\mathrm{~m}, 2 \mathrm{H}), 3.18(\mathrm{~d}, J=2.7 \mathrm{~Hz}, 1 \mathrm{H}), 2.73-2.64(\mathrm{~m}, 2 \mathrm{H})$, $1.98-1.91(\mathrm{~m}, 4 \mathrm{H}), 1.42-1.35(\mathrm{~m}, 4 \mathrm{H}) .{ }^{13} \mathrm{C}$ NMR (DMSO-d 6 ): $\delta$ $160.8,158.2,156.0,152.7,150.0,144.3,137.4,125.4\left(\mathrm{q}, J_{\mathrm{CF}}=129 \mathrm{~Hz}\right)$, 123.8, 120.1, 52.0, 49.0, 45.4, 33.1 (2C), 31.1 (2C), 29.0 (q, $J=30.0$ $\mathrm{Hz})$. MS $\left(\mathrm{ES}^{+}\right) \mathrm{m} / z 470.0[\mathrm{M}+\mathrm{H}]^{+}$.

3,3,3-Trifluoro- $\mathrm{N}$-(trans-4-((3-morpholino-1H-pyrazolo[3,4-d]pyrimidin-6-yl)amino)cyclohexyl)propane-1-sulfonamide 21. 21 was obtained by an analogous method to $1(5.27 \mathrm{~g}, 11 \mathrm{mmol}, 81 \%$ yield). ${ }^{1} \mathrm{H}$ NMR (DMSO- $\left.d_{6}\right): \delta 11.98(\mathrm{bs}, 1 \mathrm{H}), 8.82(\mathrm{~s}, 1 \mathrm{H}), 7.35(\mathrm{~d}, J$ $=7.5 \mathrm{~Hz}, 1 \mathrm{H}), 7.19(\mathrm{~s}, 1 \mathrm{H}), 3.76(\mathrm{~m}, 4 \mathrm{H}), 3.62(\mathrm{bs}, 1 \mathrm{H}), 3.33-3.30(\mathrm{~m}$, $6 \mathrm{H}), 3.16(\mathrm{bs}, 1 \mathrm{H}), 2.72-2.62(\mathrm{~m}, 2 \mathrm{H}), 1.93(\mathrm{~m}, 4 \mathrm{H}), 1.40-1.28(\mathrm{~m}$, $4 \mathrm{H})$. HRMS $\left(\mathrm{ES}^{+}\right): \mathrm{m} / z[\mathrm{M}+\mathrm{H}]^{+}$calcd for $\mathrm{C}_{18} \mathrm{H}_{27} \mathrm{~F}_{3} \mathrm{~N}_{7} \mathrm{O}_{3} \mathrm{~S} 478.1843$, found 478.1821 .

(S)-(2,4-Dichloropyrimidin-5-yl)(2-methylmorpholino)methanone 26a. A solution of (S)-2-methylmorpholine (141 g, 1.39 $\mathrm{mol})$ and TEA (141.1 g, $1.4 \mathrm{~mol})$ in DCM (1 L) was added dropwise to a stirred solution of 2,4-dichloropyrimidine-5-carbonyl chloride (268 g, $1.3 \mathrm{~mol})$ in dry DCM $(3000 \mathrm{~mL})$ at $0{ }^{\circ} \mathrm{C}$ under $\mathrm{N}_{2}$. The reaction mixture was stirred for $3 \mathrm{~h}$ at $0{ }^{\circ} \mathrm{C}$ and then quenched with $\mathrm{H}_{2} \mathrm{O}(500$ $\mathrm{mL})$. The phases were separated, and the aqueous phase was extracted with DCM $(2 \times 300 \mathrm{~mL})$. The combined organic phases were washed with $0.5 \mathrm{M} \mathrm{HCl}(1 \mathrm{~L})$ and brine $(2 \mathrm{~L})$, dried over $\mathrm{Na}_{2} \mathrm{SO}_{4}$, and then evaporated under reduced pressure. The residue was purified by flash column chromatography (petroleum/EtOAc $20 / 1$ to $1 / 1$ ) to give 26a as a yellow oil ( $188 \mathrm{~g}, 684 \mathrm{mmol}, 53 \%$ yield $).{ }^{1} \mathrm{H}$ NMR (DMSO- $\left.d_{6}\right): \delta$ $8.86(\mathrm{~s}, 1 \mathrm{H}), 4.33-4.25(\mathrm{~m}, 1 \mathrm{H}), 3.95-3.68(\mathrm{~m}, 1 \mathrm{H}), 3.58-3.37(\mathrm{~m}$, $3 \mathrm{H}), 3.17-2.64(\mathrm{~m}, 2 \mathrm{H}), 1.20-0.98(\mathrm{~m}, 3 \mathrm{H})$. MS $\left(\mathrm{ES}^{+}\right) \mathrm{m} / z 276.0[\mathrm{M}$ $+\mathrm{H}]^{+}$.

(S)-(2-Chloro-4-methoxypyrimidin-5-yl)(2-methylmorpholino)methanone $27 a$. Sodium methoxide $(40.5 \mathrm{~g}, 748.9 \mathrm{mmol})$ was added in portions to a stirred solution of $26 \mathrm{a}(188 \mathrm{~g}, 680.9 \mathrm{mmol})$ in dry THF $(2 \mathrm{~L})$ at $-40{ }^{\circ} \mathrm{C}$ under $\mathrm{N}_{2}$. The reaction mixture was stirred for $1 \mathrm{~h}$ at $-40{ }^{\circ} \mathrm{C}$, and further sodium methoxide $(9.2 \mathrm{~g}, 170.2 \mathrm{mmol})$ was added 
in one portion. The reaction mixture was stirred at $-40^{\circ} \mathrm{C}$ for $1 \mathrm{~h}$ and gradually warmed to $-10{ }^{\circ} \mathrm{C}$ for $1 \mathrm{~h}$. The reaction mixture was quenched with satd aq soln ammonium chloride $(500 \mathrm{~mL})$ at $5-10{ }^{\circ} \mathrm{C}$ and extracted with EtOAc $(3 \times 500 \mathrm{~mL})$. The combined organic phases were washed with brine $(1 \mathrm{~L})$, dried over $\mathrm{Na}_{2} \mathrm{SO}_{4}$, and evaporated under reduced pressure. The resulting crude material was purified by flash column chromatography (petroleum ether/EtOAc from 20/1 to $1 / 1)$ to give two fractions of $27 \mathrm{a}(75 \mathrm{~g}, 277 \mathrm{mmol}, 38 \%$ yield and $30 \mathrm{~g}$, $111 \mathrm{mmol}, 14 \%$ yield) as a yellow oil. This material was used in the next step without further purification.

3,3,3-Trifluoro- $N$-(trans-4-((4-methoxy-5-((S)-2-methylmorpholine-4-carbonyl)pyrimidin-2-yl)amino)cyclohexyl)propane-1-sulfonamide $28 \mathrm{a}$. To a solution of $27 \mathrm{a}(75 \mathrm{~g}, 276 \mathrm{mmol})$ in dry dioxane $(1500 \mathrm{~mL})$ was added DIPEA $(178.4 \mathrm{~g}, 1.4 \mathrm{~mol})$ and $10 \mathrm{~b}(139.4 \mathrm{~g}$, $358.8 \mathrm{mmol}$ ) in one portion at $27^{\circ} \mathrm{C}$. The resulting mixture was stirred at $120{ }^{\circ} \mathrm{C}$ for $16 \mathrm{~h}$. The mixture was cooled to room temperature and water $(800 \mathrm{~mL})$ and EtOAc $(500 \mathrm{~mL})$ added. The reaction mixture was stirred for $10 \mathrm{~min}$, then the organic phase was separated and the aqueous layer was extracted with more EtOAc $(2 \times 500 \mathrm{~mL})$. The combined organic phases were washed with brine $(2 \mathrm{~L})$, dried over $\mathrm{Na}_{2} \mathrm{SO}_{4}$, and filtered. The solvent was removed under vacuum to afford crude material which was purified by flash column chromatography (DCM/MeOH 50/1 to 20/1) to afford 28a (100 g, $196 \mathrm{mmol}, 71 \%$ yield) as a pale solid. ${ }^{1} \mathrm{H}$ NMR (DMSO- $\left.d_{6}\right): \delta 8.03(\mathrm{~s}, 1 \mathrm{H}), 7.49-7.31$ $(\mathrm{m}, 2 \mathrm{H}), 3.91-3.60(\mathrm{~m}, 5 \mathrm{H}), 3.48-3.11(\mathrm{~m}, 9 \mathrm{H}), 2.68-2.62(\mathrm{~m}, 2 \mathrm{H})$, $1.98-1.96(\mathrm{~m}, 4 \mathrm{H}), 1.43-1.09(\mathrm{~m}, 7 \mathrm{H})$.

3,3,3-Trifluoro- $N$-(trans-4-((4-methoxy-5-((S)-2-methylmorpholine-4-carbonothioyl)pyrimidin-2-yl)amino)cyclohexyl)propane-1sulfonamide 29a. 28a (117 g, $230 \mathrm{mmol})$ was dissolved in dry THF $(1700 \mathrm{~mL})$. Lawesson's reagent $(162.5 \mathrm{~g}, 401.8 \mathrm{mmol})$ was added in portions, and the resulting mixture was stirred for $2 \mathrm{~h}$ at $45{ }^{\circ} \mathrm{C}$. The reaction mixture was cooled to room temperature and quenched by addition of satd aq $\mathrm{NaHCO}_{3}(800 \mathrm{~mL})$. The reaction mixture was stirred for $10 \mathrm{~min}$ at RT and then extracted with EtOAc $(3 \times 500 \mathrm{~mL})$. The combined organic phases were washed with brine $(1 \mathrm{~L})$ and dried over $\mathrm{Na}_{2} \mathrm{SO}_{4}$. The solvent was removed under vacuum to afford a crude product which was purified by flash column chromatography (DCM/ $\mathrm{MeOH} 100 / 1$ to $20 / 1)$ to afford $29 \mathrm{a}(91 \mathrm{~g}, 173 \mathrm{mmol}, 74 \%$ yield) as a green solid. ${ }^{1} \mathrm{H}$ NMR (DMSO- $\left.d_{6}\right): \delta 8.11-8.04(\mathrm{~m}, 1 \mathrm{H}), 7.48-7.31$ $(\mathrm{m}, 2 \mathrm{H}), 5.34-5.11 \mathrm{~m}, 1 \mathrm{H}), 3.96-2.84(\mathrm{~m}, 13 \mathrm{H}), 2.73-2.59(\mathrm{~m}, 2 \mathrm{H})$, $2.00-1.78(\mathrm{~m}, 4 \mathrm{H}), 1.44-1.27(\mathrm{~s}, 4 \mathrm{H}), 1.21-1.02(\mathrm{~m}, 3 \mathrm{H})$.

2-Methyl-N-(trans-4-((3-morpholino-1H-pyrazolo [3,4-d]pyrimidin-6-yl)amino)(yclohexyl)propane-1-sulfonamide 30. 30 was obtained by an analogous method to $1(4 \mathrm{~g}, 9.1 \mathrm{mmol}, 34 \%$ yield). ${ }^{1} \mathrm{H}$ NMR (DMSO- $\left.d_{6}\right): \delta 12.04(\mathrm{~s}, 1 \mathrm{H}), 8.86(\mathrm{~s}, 1 \mathrm{H}), 7.22(\mathrm{~s}$, $1 \mathrm{H}), 7.07-7.00(\mathrm{~m}, 1 \mathrm{H}), 3.85-3.74(\mathrm{~m}, 4 \mathrm{H}), 3.73-3.62(\mathrm{~m}, 1 \mathrm{H})$, $3.41-3.31(\mathrm{~m}, 4 \mathrm{H}), 3.18-3.09(\mathrm{~m}, 1 \mathrm{H}), 2.99-2.90(\mathrm{~m}, 2 \mathrm{H}), 2.19-$ $2.10(\mathrm{~m}, 1 \mathrm{H}), 2.03-1.92(\mathrm{~m}, 4 \mathrm{H}), 1.43-1.33(\mathrm{~m}, 4 \mathrm{H}), 1.08(\mathrm{~d}, J=5.8$ $\mathrm{Hz}, 6 \mathrm{H}) .{ }^{13} \mathrm{C}$ NMR (DMSO- $d_{6}$ ): $\delta 160.5,157.3,154.0,151.5,66.2$ (2C), 60.5, 51.9, 48.9 (2C), 48.7, 33.3 (2C), 31.3 (2C), 25.0, 22.8 (2C). HRMS $\left(\mathrm{ES}^{+}\right): m / z[\mathrm{M}+\mathrm{H}]^{+}$calcd for $\mathrm{C}_{19} \mathrm{H}_{32} \mathrm{~N}_{7} \mathrm{O}_{3} \mathrm{~S} 438.2282$, found 438.2262 .

3,3,3-Trifluoro- $\mathrm{N}$-(trans-4-((4-methoxy-3-(2-methoxyphenyl)- $1 \mathrm{H}$ pyrazolo[3,4-d]pyrimidin-6-yl)amino)cyclohexyl)propane-1-sulfonamide 31. To 44a $(5.95 \mathrm{~g}, 9.7 \mathrm{mmol})$ was added $1.25 \mathrm{M} \mathrm{HCl}$ in $\mathrm{MeOH}(450 \mathrm{~mL})$ and the resulting mixture stirred at $60^{\circ} \mathrm{C}$ for $30 \mathrm{~min}$. The reaction mixture was concentrated under vacuum to a final volume of $100 \mathrm{~mL}$, satd aq $\mathrm{NaHCO}_{3}(300 \mathrm{~mL})$ added, and extracted with EtOAc $(400 \mathrm{~mL})$. The aqueous layer was extracted twice with EtOAc, and the combined organic layers dried over $\mathrm{Na}_{2} \mathrm{SO}_{4}$ and evaporated under vacuum to obtain crude material which was purified by flash column chromatography (10-90\% EtOAc in cyclohexane) to give 31 $\left(3.5 \mathrm{~g}, 9.7 \mathrm{mmol}, 68 \%\right.$ yield). ${ }^{1} \mathrm{H}$ NMR (DMSO- $\left.d_{6}\right): \delta 12.88(\mathrm{~s}, 1 \mathrm{H})$, 7.29-7.43 (m, 3H), 7.09 (d, 1H), 6.94-7.03 (m, 2H), $3.83(\mathrm{~s}, 3 \mathrm{H})$, $3.62-3.75(\mathrm{~m}, 4 \mathrm{H}), 3.26-3.31(\mathrm{~m}, 2 \mathrm{H}), 3.17(\mathrm{~s}, 1 \mathrm{H}), 2.59-2.73(\mathrm{~m}$, $2 \mathrm{H}), 1.87-2.01(\mathrm{~m}, 4 \mathrm{H}), 1.27-1.44(\mathrm{~m}, 4 \mathrm{H}) .{ }^{13} \mathrm{C}$ NMR (DMSO-d 6 ): $\delta 164.1,160.5,159.7,158.1,142.0,131.1,130.2,126.2\left(\mathrm{q}, J_{\mathrm{CF}}=127\right.$ $\mathrm{Hz}), 123.5,120.4,111.8,95.8,55.7,53.5,52.0,49.0,45.5,33.2(2 \mathrm{C})$, $31.3(2 \mathrm{C}), 28.9\left(\mathrm{q}, J_{\mathrm{CF}}=29.9 \mathrm{~Hz}\right) .{ }^{19} \mathrm{~F}$ NMR $\left(\mathrm{DMSO}-d_{6}\right): \delta-64.3$.
HRMS $\left(\mathrm{ES}^{+}\right): m / z[\mathrm{M}+\mathrm{H}]^{+}$calcd for $\mathrm{C}_{22} \mathrm{H}_{28} \mathrm{~F}_{3} \mathrm{~N}_{6} \mathrm{O}_{4} \mathrm{~S}$ 529.1840, found 529.1822 .

$\mathrm{N}$-(trans-4-((4-Methoxy-3-morpholino- $1 \mathrm{H}$-pyrazolo[3,4-d]pyrimidin-6-yl)amino)cyclohexyl)-2-methylpropane-1-sulfonamide 33. 44c $(2.63 \mathrm{~g}, 4.71 \mathrm{mmol})$ was dissolved in methanolic $\mathrm{HCl}$ solution $(218 \mathrm{~mL}, 1.25 \mathrm{M})$ and stirred at $55{ }^{\circ} \mathrm{C}$ for $1 \mathrm{~h}$. The mixture was concentrated under vacuum and EtOAC added and washed with saturated $\mathrm{NaHCO}_{3}$ solution. The organic phase was washed with brine, dried over $\mathrm{Na}_{2} \mathrm{SO}_{4}$, and evaporated under vacuum to give crude product which was purified by flash chromatography (DCM/EtOAc/ $\mathrm{MeOH} 60 / 30 / 10)$ to give 33 (1.82 g, $3.92 \mathrm{mmol}, 83 \%$ yield). ${ }^{1} \mathrm{H}$ NMR $\left(\right.$ DMSO- $\left.d_{6}\right): \delta 11.98(\mathrm{bs}, 1 \mathrm{H}), 6.98(\mathrm{~d}, J=7.6 \mathrm{~Hz}, 1 \mathrm{H}), 6.91(\mathrm{~d}, J=7.4$ $\mathrm{Hz}, 1 \mathrm{H}), 3.93(\mathrm{~s}, 3 \mathrm{H}), 3.72-3.70(\mathrm{~m}, 4 \mathrm{H}), 3.67-3.57(\mathrm{~m}, 1 \mathrm{H}), 3.22-$ $3.20(\mathrm{~m}, 4 \mathrm{H}), 3.10-3.02(\mathrm{~m}, 1 \mathrm{H}), 2.90(\mathrm{~d}, J=6.4 \mathrm{~Hz}, 2 \mathrm{H}), 2.11-2.04$ $(\mathrm{m}, 1 \mathrm{H}), 1.95-1.87(\mathrm{~m}, 4 \mathrm{H}), 1.38-1.26(\mathrm{~m}, 4 \mathrm{H}), 1.04-1.00(\mathrm{~d}, J=6.7$ $\mathrm{Hz}, 6 \mathrm{H}) .{ }^{13} \mathrm{C}$ NMR (DMSO- $d_{6}$ ): $\delta 162.9,160.6,160.2,151.7,87.3,66.3$ (2C), 60.5, 53.8, 51.9, 49.9 (2C), 33.4 (2C), 31.1 (2C), 25.0, 22.8 (2C). HRMS $\left(\mathrm{ES}^{+}\right): \mathrm{m} / z[\mathrm{M}+\mathrm{H}]^{+}$calcd for $\mathrm{C}_{20} \mathrm{H}_{34} \mathrm{~F}_{3} \mathrm{~N}_{7} \mathrm{O}_{4} \mathrm{~S}$ 468.2387, found 468.2367 .

$\mathrm{N}$-(trans-4-((4-Methoxy-3-((R)-3-methylmorpholino)- $1 \mathrm{H}$ pyrazolo [3,4-d]pyrimidin-6-yl)amino)cyclohexyl)-2-methylpropane-1-sulfonamide 39. 39 was obtained by an analogous method to 33 (33g, $68.8 \mathrm{mmol}, 78 \%$ yield). ${ }^{1} \mathrm{H}$ NMR (DMSO- $\left.d_{6}\right): \delta 11.96$ (bs, $1 \mathrm{H}), 6.98(\mathrm{~d}, J=7.4 \mathrm{~Hz}, 1 \mathrm{H}), 6.90(\mathrm{~d}, J=7.4 \mathrm{~Hz}, 1 \mathrm{H}), 3.99-3.93(\mathrm{~m}$, $1 \mathrm{H}), 3.91(\mathrm{~s}, 3 \mathrm{H}), 3.79-3.70(\mathrm{~m}, 2 \mathrm{H}), 3.64-3.51(\mathrm{~m}, 3 \mathrm{H}), 3.27-3.09$ $(\mathrm{m}, 2 \mathrm{H}), 3.08-3.01(\mathrm{~m}, 1 \mathrm{H}), 2.88(\mathrm{~d}, J=6.4 \mathrm{~Hz}, 2 \mathrm{H}), 2.06$ (sept, $J=$ $6.6 \mathrm{~Hz}, 1 \mathrm{H}), 1.93-1.85(\mathrm{~m}, 4 \mathrm{H}), 1.36-1.26(\mathrm{~m}, 4 \mathrm{H}), 1.04-0.99(\mathrm{~m}$, $9 \mathrm{H}) .{ }^{13} \mathrm{C}$ NMR (DMSO- $\left.d_{6}\right): \delta 163.0,160.4,160.0,150.8,87.5,71.0$, 66.6, 60.5, 53.8, 51.9, 51.1, 49.0, 44.3, 33.3 (2C), 31.4 (2C), 26.8, 25.0, 22.8 (2C), 12.9. HRMS $\left(\mathrm{ES}^{+}\right): m / z[\mathrm{M}+\mathrm{H}]^{+}$calcd for $\mathrm{C}_{21} \mathrm{H}_{36} \mathrm{~N}_{7} \mathrm{O}_{4} \mathrm{~S}$ 482.2544, found 482.2523. Enantiopurity determined using a chiral column: $250 \mathrm{~mm}$ Chiralpak IA, $150 \mathrm{~mm} \times 4.6 \mathrm{~mm} 5 \mu \mathrm{m}$, heptane/ $\mathrm{EtOH}=65 / 35+0.2 \%$ iso-propyl amine, $1.0 \mathrm{~mL} / \mathrm{min}, 298 \mathrm{~K}, 254 \mathrm{~nm}$. First enantiomer (39, only peak detected) $R_{\mathrm{t}}=8.5 \mathrm{~min}$, second enantiomer (compound 40, not detected) $R_{\mathrm{t}}=15.5 \mathrm{~min}$. ee measured: $100 \%$.

3-Bromo-4,6-dichloro-1-(tetrahydro-2H-pyran-2-yl)-1Hpyrazolo[3,4-d]pyrimidine 41a. A solution of 3-bromo-4,6-dichloro$1 \mathrm{H}$-pyrazolo[3,4-d]pyrimidine $(40 \mathrm{~g}, 149 \mathrm{mmol}), 3,4-$ dihydro- $2 \mathrm{H}$ pyran $(41 \mathrm{~mL}, 447 \mathrm{mmol})$, and $p$-toluenesulfonic acid monohydrate $(5.7 \mathrm{~g}, 30 \mathrm{mmol})$ in THF $(650 \mathrm{~mL})$ was stirred at $70^{\circ} \mathrm{C}$ for $2 \mathrm{~h}$. After cooling, the solvent was evaporated, ether $(200 \mathrm{~mL})$ added, and the resulting suspension stirred for $2 \mathrm{~h}$ at $40{ }^{\circ} \mathrm{C}$, slowly cooled, and the resulting solid collected, washed with ether, and dried to give 41 a $(41.5$ g, $118 \mathrm{mmol}, 79 \%$ yield). ${ }^{1} \mathrm{H} \mathrm{NMR}\left(\mathrm{CDCl}_{3}-d_{6}\right): \delta 6.00$ (dd, $J=2.6$ and $6.0 \mathrm{~Hz}, 1 \mathrm{H}), 4.18-4.10(\mathrm{~m}, 1 \mathrm{H}), 3.84-3.76(\mathrm{~m}, 1 \mathrm{H}), 2.62-2.49(\mathrm{~m}$, $1 \mathrm{H}), 2.20-2.13(\mathrm{~m}, 1 \mathrm{H}), 1.86-1.63(\mathrm{~m}, 4 \mathrm{H}) . \mathrm{MS}\left(\mathrm{ES}^{+}\right) \mathrm{m} / z$ 349.0, 351.0, $353.0[\mathrm{M}+\mathrm{H}]^{+}$.

3-Bromo-4,6-dichloro-1-((2-(trimethylsilyl)ethoxy)methyl)-1Hpyrazolo[3,4-d]pyrimidine 41b. A solution of 3-bromo-4,6-dichloro$1 \mathrm{H}$-pyrazolo[3,4- $d]$ pyrimidine $(65.5 \mathrm{~g}, 244 \mathrm{mmol})$ in DCM $(1.5 \mathrm{~L})$ at 0 ${ }^{\circ} \mathrm{C}$ was added DIPEA $(125 \mathrm{~mL}, 733 \mathrm{mmol})$ dropwise $(30 \mathrm{~min})$ and the resulting solution stirred at $0{ }^{\circ} \mathrm{C}$ for $5 \mathrm{~min}$. After this time, 2(trimethylsilyl)ethoxymethyl chloride $(51.5 \mathrm{~mL}, 293 \mathrm{mmol}$ ) was added dropwise $(40 \mathrm{~min})$ and stirred at $3-4{ }^{\circ} \mathrm{C}$ for $1.5 \mathrm{~h}$. Water $(1 \mathrm{~L})$ was added to the reaction and the phases separated. The organic layer was washed with $\mathrm{H}_{2} \mathrm{O}(1 \mathrm{~L})$, dried over $\mathrm{Na}_{2} \mathrm{SO}_{4}$, filtered, and concentrated to give $41 \mathrm{~b}$ as a brown solid which was used without purification $(101 \mathrm{~g}$, $245 \mathrm{mmol}$, quant yield). ${ }^{1} \mathrm{H}$ NMR (DMSO- $\left.d_{6}\right): \delta 5.7(\mathrm{~s}, 2 \mathrm{H}), 3.6(\mathrm{dd}, J$ $=8.1,8.1 \mathrm{~Hz}, 2 \mathrm{H}), 0.85(\mathrm{dd}, J=8.1,8.1 \mathrm{~Hz}, 2 \mathrm{H}), 0.95(\mathrm{~s}, 9 \mathrm{H}) . \mathrm{MS}$ $\left(\mathrm{ES}^{+}\right) \mathrm{m} / z$ 395.0, $397.0[\mathrm{M}+\mathrm{H}]^{+}$.

3-Bromo-6-chloro-4-methoxy-1-(tetrahydro-2H-pyran-2-yl)- $1 \mathrm{H}$ pyrazolo[3,4-d]pyrimidine 42a. To 41a (35.8 g, $102 \mathrm{mmol})$ in $\mathrm{MeOH}$ $(160 \mathrm{~mL})$ was added a solution of sodium methoxide $(5.5 \mathrm{~g}, 102 \mathrm{mmol})$ in $\mathrm{MeOH}(500 \mathrm{~mL})$ dropwise over $1 \mathrm{~h}$ and the resulting suspension stirred for $30 \mathrm{~min}$. Solvent was evaporated, EtOAc added and washed with satd aq $\mathrm{NaHCO}_{3}$ then dried over sodium sulfate and solvent evaporated to give $42 \mathrm{a}$ which was used without purification $(35.5 \mathrm{~g}) .{ }^{1} \mathrm{H}$ NMR (DMSO- $\left.d_{6}\right): \delta 5.84(\mathrm{dd}, J=2.5$ and $5.8 \mathrm{~Hz}, 1 \mathrm{H}), 4.14(\mathrm{~s}, 3 \mathrm{H})$, 3.99-3.93 (m, 1H), 3.73-3.68 (m, 1H), 2.35-2.26 (m, 1H), 2.03- 
$1.96(\mathrm{~m}, 1 \mathrm{H}), 1.93-1.87(\mathrm{~m}, 1 \mathrm{H}), 1.80-1.72(\mathrm{~m}, 1 \mathrm{H}), 1.60-1.53(\mathrm{~m}$, 2H). MS $\left(\mathrm{ES}^{+}\right) m / z 347,349[\mathrm{M}+\mathrm{H}]^{+}$.

3-Bromo-6-chloro-4-methoxy-1-((2-(trimethylsilyl)ethoxy)methyl)-1H-pyrazolo[3,4-d]pyrimidine 42b. To $41 \mathrm{~b}$ (772 g, 1.94 $\mathrm{mol})$ in $\mathrm{MeOH}(20 \mathrm{~L})$ was added sodium methoxide $(115.2 \mathrm{~g}, 2.13$ $\mathrm{mol})$ in $\mathrm{MeOH}(230 \mathrm{~mL})$ dropwise and the resulting solution stirred at room temperature for $30 \mathrm{~min}$. The reaction mixture was partitioned between EtOAc $(10 \mathrm{~L})$ and brine $(2 \mathrm{~L})$ and the organic layer separated, washed with brine $(2 \mathrm{~L})$, dried over $\mathrm{Na}_{2} \mathrm{SO}_{4}$, filtered, and concentrated. This residue was purified by column chromatography on silica gel (100-200 mesh silica gel) eluted with petroleum ether:EtOAc $(100: 1-100: 2)$ to give a crude product. This crude product was purified by recrystallization from petroleum ether $(1 \mathrm{~L})$ to give $\mathbf{4 2 b}$ as a white solid (450 g, $1.14 \mathrm{~mol}, 58.8 \%$ yield). ${ }^{1} \mathrm{H}$ NMR (DMSO- $\left.d_{6}\right): \delta$ $5.62(\mathrm{~s}, 2 \mathrm{H}), 4.14(\mathrm{~s}, 3 \mathrm{H}), 3.59(\mathrm{t}, J=8.2 \mathrm{~Hz}, 2 \mathrm{H}), 0.84(\mathrm{t}, J=8.1 \mathrm{~Hz}$, $2 \mathrm{H}), 0.07(\mathrm{~s}, 9 \mathrm{H})$. MS $\left(\mathrm{ES}^{+}\right) \mathrm{m} / z$ 392.9. 395.0 $[\mathrm{M}+\mathrm{H}]^{+}$.

$\mathrm{N}$-(trans-4-((3-Bromo-4-methoxy-1-(tetrahydro-2H-pyran-2-yl)$1 \mathrm{H}$-pyrazolo[3,4-d]pyrimidin-6-yl)amino)cyclohexyl)-2-methylpropane-1-sulfonamide $43 a$. To a stirred solution of $42 \mathrm{a}$ (7.82 g, 22.44 $\mathrm{mmol})$ and $10 \mathrm{a}(6 \mathrm{~g}, 17.26 \mathrm{mmol})$ in ethanol $(172 \mathrm{~mL})$ was added DIPEA $(12 \mathrm{~mL}, 69.04 \mathrm{mmol})$ and the mixture heated to $70{ }^{\circ} \mathrm{C}$ and stirred for 2 days. Solvent was evaporated and the crude material purified by flash chromatography (30-50\% ethyl acetate/cyclohexane) to afford 43a (5.5 g, $10.1 \mathrm{mmol}, 58 \%$ yield). ${ }^{1} \mathrm{H}$ NMR (DMSO- $\left.d_{6}\right): \delta$ $7.52(\mathrm{dd}, J=9.5,17.0 \mathrm{~Hz}, 1 \mathrm{H}), 7.04(\mathrm{~d}, J=7.6 \mathrm{~Hz}, 1 \mathrm{H}), 5.65-5.55(\mathrm{~m}$, $1 \mathrm{H}), 4.05-3.96(\mathrm{~m}, 2 \mathrm{H}), 3.67(\mathrm{~s}, 2 \mathrm{H}), 3.33(\mathrm{~s}, 3 \mathrm{H}), 2.92-2.89(\mathrm{~m}$, $2 \mathrm{H}), 2.36-2.27(\mathrm{~m}, 1 \mathrm{H}), 2.13-2.06(\mathrm{~m}, 1 \mathrm{H}), 1.94(\mathrm{~s}, 3 \mathrm{H}), 1.83(\mathrm{dd}, J$ $=13.2,13.2 \mathrm{~Hz}, 1 \mathrm{H}), 1.54(\mathrm{~s}, 2 \mathrm{H}), 1.36(\mathrm{~d}, J=18.6 \mathrm{~Hz}, 6 \mathrm{H}), 1.05-1.01$ $(\mathrm{m}, 6 \mathrm{H})$. MS $\left(\mathrm{ES}^{+}\right) \mathrm{m} / z$ 547.3, 545.3 $[\mathrm{M}+\mathrm{H}]^{+}$.

3,3,3-Trifluoro- $N$-(trans-4-((4-methoxy-3-(2-methoxyphenyl)-1((2-(trimethylsilyl) ethoxy)methyl)-1H-pyrazolo[3,4-d]pyrimidin-6yl)amino)cyclohexyl)propane-1-sulfonamide 44a. To 43b (3.9 g, $6.6 \mathrm{mmol})$ and 2-methoxyphenylboronic acid $(1.37 \mathrm{~g}, 8.9 \mathrm{mmol})$ was added $\left[1,1^{\prime}\right.$-bis(diphenylphosphino)ferrocene $]$ palladium(II) dichloride $(483 \mathrm{mg}, 0.66 \mathrm{mmol})$, sodium carbonate $(2.1 \mathrm{~g}, 39.6 \mathrm{mmol})$, DME $(160 \mathrm{~mL})$, and $\mathrm{H}_{2} \mathrm{O}(80 \mathrm{~mL})$ under argon. The resulting mixture was stirred at $110^{\circ} \mathrm{C}$ for $30 \mathrm{~min}$. The reaction mixture was filtered then concentrated under vacuum. The residue was taken up in EtOAc and washed with a satd aq soln $\mathrm{NH}_{4} \mathrm{CI}$. The layers were separated and the organic phase washed with brine, dried over $\mathrm{Na}_{2} \mathrm{SO}_{4}$, and concentrated. The crude material was purified by flash column chromatography $(6: 4$ cyclohexane in EtOAc) to afford 44a which was used without further purification (4.04 g, $6.6 \mathrm{mmol}$, quant yield). $\mathrm{MS}\left(\mathrm{ES}^{+}\right) \mathrm{m} / z 613.3[\mathrm{M}+$ $\mathrm{H}]^{+}$.

3,3,3-Trifluoro- $N$-(trans-4-((4-methoxy-3-morpholino-1-(tetrahydro-2H-pyran-2-yl)-1H-pyrazolo [3,4-d]pyrimidin-6-yl)amino)cyclohexyl)propane-1-sulfonamide $44 \mathrm{~b}$. A mixture of $43 \mathrm{~b}$ (0.25 g, $0.43 \mathrm{mmol})$, morpholine $(0.186 \mathrm{~mL}, 2.14 \mathrm{mmol})$, cesium carbonate $(0.39 \mathrm{~g}, 1.20 \mathrm{mmol}), 4.5$-bis(diphenylphospino)-9.9-dimethylxanthene $(0.03 \mathrm{~g}, 0.05 \mathrm{mmol})$, and palladium acetate $(9.6 \mathrm{mg}, 0.043 \mathrm{mmol})$ in 1,4-dioxane $(4.08 \mathrm{~mL})$ was purged with argon and heated at $110{ }^{\circ} \mathrm{C}$ overnight. The resulting mixture was partitioned between ethyl acetate $(75 \mathrm{~mL})$ and water $(150 \mathrm{~mL})$. The phases were separated and the aqueous phase extracted with ethyl acetate $(1 \times 75 \mathrm{~mL})$. The organic phases were combined with two further additional experiments, dried with $\mathrm{Na}_{2} \mathrm{SO}_{4}$, filtered, and concentrated to give $44 \mathrm{~b}$ as a brown oil ( 250 $\mathrm{mg}, 0.42 \mathrm{mmol}, 45 \%$ overall yield from all three experiments) which was used without purification. $\mathrm{MS}\left(\mathrm{ES}^{+}\right) \mathrm{m} / z 592.2[\mathrm{M}+\mathrm{H}]^{+}$.

$\mathrm{N}$-(trans-4-((4-Methoxy-3-morpholino-1-(tetrahydro-2H-pyran2-yl)-1H-pyrazolo[3,4-d]pyrimidin-6-yl)amino)cyclohexyl)-2-methylpropane-1-sulfonamide $44 c$. The reaction was run in two batches: To a mixture of $43 \mathrm{a}(2.6 \mathrm{~g}, 4.8 \mathrm{mmol})$, sodium tert-butoxide (1.4 g, 14.3 $\mathrm{mmol})$, xantphos $(0.66 \mathrm{~g}, 1.14 \mathrm{mmol})$, and $\mathrm{Pd}_{2} \mathrm{dba}_{3}(0.436 \mathrm{~g}, 0.48$ $\mathrm{mmol})$ in dioxane $(160 \mathrm{~mL})$ was added morpholine $(4.16 \mathrm{~mL}, 47.6$ $\mathrm{mmol}$ ) and the mixture heated at $110{ }^{\circ} \mathrm{C}$ for $30 \mathrm{~min}$. The reaction mixture was filtered through Celite, then diluted with ethyl acetate and washed with satd $\mathrm{NH}_{4} \mathrm{Cl}$. The aqueous phase was extracted with ethyl acetate, washed with brine, dried over $\mathrm{Na}_{2} \mathrm{SO}_{4}$, filtered, and evaporated. The crude material from both batches was combined and purified by flash chromatography (50-80\% EtOAc/cyclohexane) to give $44 \mathrm{c}(2.6$ g, $4.7 \mathrm{mmol}, 49 \%$ overall yield from both experiments). ${ }^{1} \mathrm{H}$ NMR
(DMSO- $\left.d_{6}\right): \delta 7.18-7.09(\mathrm{~m}, 1 \mathrm{H}), 7.00(\mathrm{~d}, J=8.0 \mathrm{~Hz}, 1 \mathrm{H}), 5.55-5.49$ $(\mathrm{m}, 1 \mathrm{H}), 4.00-3.91(\mathrm{~m}, 4 \mathrm{H}), 3.78-3.64(\mathrm{~m}, 5 \mathrm{H}), 3.58-3.50(\mathrm{~m}, 1 \mathrm{H})$, $3.30-3.22(\mathrm{~m}, 4 \mathrm{H}), 3.11-3.05(\mathrm{~m}, 1 \mathrm{H}), 2.91(\mathrm{~d}, J=6.4 \mathrm{~Hz}, 2 \mathrm{H})$, $2.42-2.31(\mathrm{~m}, 1 \mathrm{H}), 2.09$ (sept, $J=6.7 \mathrm{~Hz}, 1 \mathrm{H}), 2.03-1.89(\mathrm{~m}, 5 \mathrm{H})$, $1.80-1.62(\mathrm{~m}, 2 \mathrm{H}), 1.55-1.50(\mathrm{~m}, 2 \mathrm{H}), 1.41-1.30(\mathrm{~m}, 4 \mathrm{H}), 1.04(\mathrm{~d}, J$ $=6.7 \mathrm{~Hz}, 6 \mathrm{H}) . \mathrm{MS}\left(\mathrm{ES}^{+}\right) \mathrm{m} / z 552.5[\mathrm{M}+\mathrm{H}]^{+}$.

(S)-N-trans-(4-((4-Methoxy-3-(3-methylmorpholino)-1-((2(trimethylsilyl)ethoxy)methyl)-1H-pyrazolo[3,4-d]pyrimidin-6-yl)amino)cyclohexyl)-2-methylpropane-1-sulfonamide 44e. A mixture of $43 \mathrm{~d}(35 \mathrm{~g}, 59.2 \mathrm{mmol})$ in 1,4-dioxane $(1000 \mathrm{~mL})$ was purged with argon, (R)-3-methylmorpholine (59.8 g, $592 \mathrm{mmol})$, Tris(dibenzylideneacetone)dipalladium $(0)(5.42 \mathrm{~g}, 5.92 \mathrm{mmol})$, and dicyclohexyl (2',6'-diisopropoxy-[1,1'-biphenyl]-2-yl)phosphine (5.52 g, $11.83 \mathrm{mmol}$ ) added and purged with argon. Potassium bis (trimethylsilyl)amide ( $0.5 \mathrm{M}$ in toluene, $237 \mathrm{~mL}, 118 \mathrm{mmol}$ ) was added and purged and the mixture stirred at $110{ }^{\circ} \mathrm{C}$ for $2 \mathrm{~h}$. The crude mixture was cooled, filtered through Celite, partitioned between ethyl acetate $(500 \mathrm{~mL})$ and brine $(1 \mathrm{~L})$, the phases separated, and the organic phase washed with further brine $(1 \mathrm{~L})$. The combined aqueous layers were extracted with ethyl acetate $(1 \mathrm{~L})$ and the organic layers combined, dried over $\mathrm{Na}_{2} \mathrm{SO}_{4}$, filtered, and concentrated. Crude material was purified by flash chromatography (cyclohexane/EtOAc gradient $0-30 \%)$ to give $44 \mathrm{e}$ as a brown solid $(16.91 \mathrm{~g}, 27.6 \mathrm{mmol}$, 47\%). ${ }^{1} \mathrm{H}$ NMR (DMSO- $\left.d_{6}\right): \delta 7.20-7.10(\mathrm{~m}, 1 \mathrm{H}), 7.04-6.96(\mathrm{~m}$, $1 \mathrm{H}), 5.35-5.25(\mathrm{~m}, 2 \mathrm{H}), 4.05-3.90(\mathrm{~m}, 4 \mathrm{H}), 3.82-3.63(\mathrm{~m}, 3 \mathrm{H})$, $3.61-3.49(\mathrm{~m}, 3 \mathrm{H}), 3.26-3.15(\mathrm{~m}, 2 \mathrm{H}), 3.09-3.03(\mathrm{~m}, 1 \mathrm{H}), 2.89(\mathrm{~d}, J$ $=6.4 \mathrm{~Hz}, 2 \mathrm{H}), 2.07(\mathrm{sept}, J=6.7 \mathrm{~Hz}, 1 \mathrm{H}), 1.95-1.86(\mathrm{~m}, 3 \mathrm{H}), 1.38(\mathrm{~s}$, $3 \mathrm{H}), 1.36-1.28(\mathrm{~m}, 3 \mathrm{H}), 1.04(\mathrm{~d}, J=6.6 \mathrm{~Hz}, 3 \mathrm{H}), 1.00(\mathrm{~d}, J=6.7 \mathrm{~Hz}$, $6 \mathrm{H}), 0.84-0.76(\mathrm{~m}, 2 \mathrm{H}),-0.10(\mathrm{~s}, 9 \mathrm{H}) . \mathrm{MS}\left(\mathrm{ES}^{+}\right) \mathrm{m} / z 612.3[\mathrm{M}+$ $\mathrm{H}]^{+}$.

Intramacrophage Leishmania donovani Assay. This assay was conducted as previously described. ${ }^{14}$

Kinetic Aqueous Solubility Assessment. ${ }^{23}$ The aqueous solubility of test compounds were measured using an in-house method utilizing quantification via chemiluminescent nitrogen detection (CLND): a $5 \mu \mathrm{L}$ of $10 \mathrm{mM}$ DMSO stock solution was diluted to 100 $\mu \mathrm{L}$ with $\mathrm{pH} 7.4$ phosphate buffered saline and equilibrated for $1 \mathrm{~h}$ at RT, filtered through Millipore Multiscreen HTS-PCF filter plates (MSSL $\mathrm{BPC}$ ). The eluent is quantified by suitably calibrated flow injection CLND. This assay has a dynamic range between the lower detection limit of 1 and $500 \mu \mathrm{M}$, governed by the protocol's 1:20 dilution into $\mathrm{pH}$ 7.4 phosphate buffer solution from nominal $10 \mathrm{mM}$ DMSO stock.

Solubility of Solid Compounds in Fasted Simulated Intestinal Fluid. ${ }^{32}$ Solubility of test compounds in fasted simulated intestinal fluid (FaSSIF) were determined at pH 6.5 after $4 \mathrm{~h}$ equilibration at room temperature. One $\mathrm{mL}$ of FaSSIF buffer $(3 \mathrm{mM}$ sodium taurocholate, $0.75 \mathrm{mM}$ lecithin in sodium phosphate buffer at $\mathrm{pH}$ 6.5) was added to manually weighed $1 \mathrm{mg}$ of solid compound in a 2 $\mathrm{mL}$ HPLC autosampler vial. The resulting suspension is shaken at 900 $\mathrm{rpm}$ for $4 \mathrm{~h}$ at room temperature and then transferred to a Multiscreen HTS, 96-well solubility filter plate. The residual solid was removed by filtration. The supernatant solution was quantified by HPLC-UV using single-point calibration of a known concentration of the compound in DMSO. The dynamic range of the assay was $1-1000 \mu \mathrm{g} / \mathrm{mL}$.

Measurement of ChromLogD. ${ }^{23,31}$ The chromatographic hydrophobicity index $(\mathrm{CHI})^{45}$ values are measured using reversed phase HPLC column $(50 \mathrm{~mm} \times 2 \mathrm{~mm} 3 \mu \mathrm{M}$ Gemini NX C18, Phenomenex, $\mathrm{UK}$ ) with fast acetonitrile gradient at starting mobile phase of $\mathrm{pHs} 2$, 7.4, and 10.5. CHI values are derived directly from the gradient retention times by using a calibration line obtained for standard compounds. The CHI value approximated the volume\% organic concentration when the compound was eluted. CHI is linearly transformed into ChromLogD ${ }^{23,31}$ by least-squares fitting of experimental $\mathrm{CHI}$ values to calculated ClogP values for over $20 \mathrm{~K}$ research compounds using the following formula: Chrom $\log \mathrm{D}=0.0857 \times \mathrm{CHI}-$ 2.00 .

Stability in Microsomes. Test compound $(0.5 \mu \mathrm{M})$ was incubated with either female CD1 mouse (Xenotech) or human (IVT) liver microsomes and their action started with addition of excess NADPH (8 $\mathrm{mg} / \mathrm{mL} 50 \mathrm{mM}$ potassium phosphate buffer, $\mathrm{pH}$ 7.4). Immediately, at 
time zero, then at $3,6,9,15$, and $30 \mathrm{~min}$, an aliquot $(50 \mu \mathrm{L})$ of the incubation mixture was removed and mixed with acetonitrile $(100 \mu \mathrm{L})$ to stop the reaction. Internal standard was added to all samples, the samples centrifuged to sediment precipitated protein, and the plates then sealed prior to UPLC-MS/MS analysis using a Quattro Premier XE (Waters Corporation, USA). XLfit (IDBS, UK) was used to calculate the exponential decay and consequently the rate constant $(k)$ from the ratio of the peak area of test compound to internal standard at each time point. The rate of intrinsic clearance $\left(\mathrm{Cl}_{\mathrm{i}}\right)$ of each test compound was then calculated using the equation $\mathrm{Cl}_{\mathrm{i}}(\mathrm{mL} / \mathrm{min} / \mathrm{g}$ liver $)=k \times V \times$ microsomal protein yield, where $V(\mathrm{~mL} / \mathrm{mg}$ protein $)$ is the incubation volume $/ \mathrm{mg}$ protein added and microsomal protein yield is taken as $52.5 \mathrm{mg}$ protein/g liver. Verapamil $(0.5 \mu \mathrm{M})$ was used as a positive control to confirm acceptable assay performance.

Plasma Protein Binding Experiments. In brief, a 96-well equilibrium dialysis apparatus was used to determine the free fraction in mouse plasma for each compound (HT Dialysis LLC, Gales Ferry, $\mathrm{CT})$. Membranes (12-14 kDa A cutoff) were conditioned in deionized water for $60 \mathrm{~min}$, followed by conditioning in 80:20 deionized water:ethanol for $20 \mathrm{~min}$ and then rinsed in isotonic buffer before use. Female CD1 mouse plasma was removed from the freezer and allowed to thaw on the day of experiment. Thawed plasma was then centrifuged (Allegra X12-R, Beckman Coulter, USA), spiked with test compound (final concentration $10 \mu \mathrm{g} / \mathrm{mL}$ ), and $150 \mu \mathrm{L}$ aliquots $(n=6$ replicate determinations) loaded into the 96-well equilibrium dialysis plate. Dialysis vs isotonic buffer $(150 \mu \mathrm{L})$ was carried out for $5 \mathrm{~h}$ in a temperature controlled incubator at ca. $37^{\circ} \mathrm{C}$ (Barworld scientific Ltd., UK) using an orbital microplate shaker at $100 \mathrm{rpm}$ (Barworld scientific Ltd., UK). At the end of the incubation period, $50 \mu \mathrm{L}$ aliquots of plasma or buffer were transferred to micronic tubes (Micronic BV, The Netherlands) and the composition in each tube balanced with control fluid ( $50 \mu \mathrm{L})$, such that the volume of buffer to plasma was the same. Sample extraction was performed by the addition of $200 \mu \mathrm{L}$ of acetonitrile containing an appropriate internal standard. Samples were allowed to $\mathrm{mix}$ for $1 \mathrm{~min}$ and then centrifuged at $3000 \mathrm{rpm}$ in 96-well blocks for 15 min (Allegra X12-R, Beckman Coulter, USA), after which $150 \mu \mathrm{L}$ of supernatant was removed to $50 \mu \mathrm{L}$ of water. All samples were analyzed by UPLC-MS/MS on a Quattro Premier XE mass spectrometer (Waters Corporation, USA). The unbound fraction was determined as the ratio of the peak area in buffer to that in plasma.

Melting Point (mtp) Determination. Determination of melting point of compounds were measured by thermal analysis, performing differential scanning calorimetry, (DSC) experiments, which measured temperatures and heat flows associated with thermal transitions in a material. The equipment utilized was from TA Instruments (Q20, RCS Refrigerator), using the system Software Q Advantage for QSeries and Analysis Software TA universal analysis.

As general operating conditions, the following were set up: start temperature $25^{\circ} \mathrm{C}$, end temperature $350{ }^{\circ} \mathrm{C}$, heating rate $10{ }^{\circ} \mathrm{C} / \mathrm{min}$. The sample quantity ranged from 1 to $3 \mathrm{mg}$, placed in a hermetic pan. The corresponding analysis with the thermal transitions occurred was obtained based on a reference blank sample (empty pan) to get the difference between the sample and the reference in the energy response when heating equally both pans.

$\mathrm{p} K_{\mathrm{a}}$ Determination. ${ }^{35}$ The Sirius T3 (Sirius Analytical Inc., UK) instrument has been used for $\mathrm{p} K_{\mathrm{a}}$ determination of the compounds. The $\mathrm{p} K_{\mathrm{a}}$ determination is based on acid-base titration, and the protonation/deprotonation of the molecule is measured either by UV spectroscopy or potentiometrically. The $\mathrm{p} K_{\mathrm{a}}$ value is calculated from the $\mathrm{pH}$, where the $50-50 \%$ of the protonated and unprotonated form of the molecules are present.

The UV-metric method provides $\mathrm{p} K_{\mathrm{a}}$ results for samples with chromophores whose UV absorbance changes as a function of $\mathrm{pH}$. It typically required $5 \mu \mathrm{L}$ of a $10 \mathrm{mM}$ solution of the samples, and the UV absorbance was monitored over $54 \mathrm{pH}$ values in a buffered solution in about $5 \mathrm{~min}$.

When the ionization center was far from the UV, the chromophore $\mathrm{pH}$-metric method based on potentiometric acid-base titration was used. The $\mathrm{pH}$ of each point in the titration curve was calculated using equations that contain $\mathrm{p} K_{\mathrm{a}}$, and the calculated points were fitted to the measured curve by manipulating the $\mathrm{p} K_{\mathrm{a}}$. The $\mathrm{p} K_{\mathrm{a}}$ that provided the best fit was taken to be the measured $\mathrm{p} K_{\mathrm{a}}$.

Usually $0.5-1 \mathrm{mg}$ of solid material is required for the measurements. When the compound precipitated at some point during the $\mathrm{pH}$ titration, the cosolvent method using methanol was applied using various concentration of cosolvent. The $\mathrm{p} K_{\mathrm{a}}$ in water was calculated using the Yasuda-Shedlovsky extrapolation method.

X-ray Diffraction Studies of 1 and 15. Data for both studies were collected with an Oxford Diffraction Gemini A Ultra diffractometer at $150(2) \mathrm{K}$ using $\mathrm{Cu} \mathrm{K} \alpha \mathrm{X}$-radiation $(\lambda=1.54178 \AA)$.

Crystal Data and Refinement Summary for $1 . \mathrm{C}_{19} \mathrm{H}_{28} \mathrm{~F}_{3} \mathrm{~N}_{7} \mathrm{O}_{3} \mathrm{~S} ; \mathrm{M}$ $=491.54$; colorless tablet from the slow evaporation of a solution of 1 in DMSO and 1-butanol; $0.32 \mathrm{~mm} \times 0.15 \mathrm{~mm} \times 0.07 \mathrm{~mm}$; triclinic; space group P1 (\#1); $a=8.68517(18) \AA ̊ ., b=16.0121$ (3) $\AA$, $c=17.5996(4) \AA$, $\alpha=95.8623(16)^{\circ}, \beta=102.6295(18)^{\circ}, \gamma=100.2962(16)^{\circ}, V=$ $2324.30(8) \AA^{3} ; Z=4 ; D_{\text {calc }}=1.405 \mathrm{Mgm}^{-3} ; \theta_{\max }=67.03^{\circ}$; reflections collected $=33974 ;$ independent reflections $=33974 ; R_{\text {int }}=0.0000$ (HKLF 5 treatment owing to crystal splitting); coverage $=99.2 \%$; restraints $=896$; parameters $=1395 ; S=1.041 ; R_{1}[I>2 \sigma(I)]=0.0526$; $w R_{2}($ all data $)=0.1479$; absolute structure parameter $=0.022(9)$; and largest difference peak and hole $=0.572$ and $0.322 \mathrm{e}^{-3}$.

Crystal Data and Refinement Summary for 15. $\mathrm{C}_{19} \mathrm{H}_{22} \mathrm{~F}_{3} \mathrm{~N}_{7} \mathrm{O}_{2} \mathrm{~S}$; $\mathrm{M}=469.50$; colorless block from the slow evaporation and seeding of a solution of 15 in DMSO and DMF; $0.21 \mathrm{~mm} \times 0.14 \mathrm{~mm} \times 0.06 \mathrm{~mm}$; triclinic; space group P1 (\#2); $a=8.5590(2) \AA ̊, b=8.6492(2) \AA, c=$ 14.0372(4) $\AA, \alpha=85.196(2)^{\circ}, \beta=89.219(2)^{\circ}, \gamma=85.087(2)^{\circ}, V=$ $1031.68(4) \AA^{3} ; Z=2 ; D_{\text {calc }}=1.511 \mathrm{Mgm}^{-3} ; \theta_{\max }=66.74^{\circ}$; reflections collected $=22081$; independent reflections $=3644 ; R_{\text {int }}=0.0351$; coverage $=99.4 \%$; restraints $=0$; parameters $=301 ; S=1.048 ; R_{1}[I>$ $2 \sigma(I)]=0.0346 ; w R_{2}($ all data $)=0.0956$; and largest difference peak and hole $=0.253$ and $0.454 \mathrm{e}^{-3}$.

A description of the refinements and the full tables associated with the crystal structures are given in the Supporting Information. Crystallographic information files have been deposited with the Cambridge Crystallographic Data Centre. CCDC 1857125 (1) and 1857128 (15) contain the supplementary crystallographic data for this paper. The data can be obtained free of charge from The Cambridge Crystallographic Data Centre via www.ccdc.cam.ac.uk/structures.

In Vivo Pharmacokinetics. Mouse. Test compound $\mathbf{1 5}$ was dosed intravenously or orally by gavage as a solution at 3 or $10 \mathrm{mg}$ free base $/ \mathrm{kg}$ respectively (dose volume, 5 or $10 \mathrm{~mL} / \mathrm{kg}$ respectively; dose vehicle, $10 \%(\mathrm{v} / \mathrm{v}$ ) dimethyl sulfoxide (DMSO), $60 \%$ polyethylene glycol 400 , and $30 \%$ deionized water) to female Balb/c mice $(n=3)$. Blood samples were taken from each mouse at $0.08,0.25,0.5,1,2,4,6,8$, and $24 \mathrm{~h}$ post dose and mixed with two volumes of distilled water. After suitable sample preparation, the concentration of test compound in blood was determined by UPLC-MS/MS using a Quattro Premier XE (Waters, USA). Pharmacokinetic parameters were derived from the mean blood concentration time curve using PK solutions software v 2.0 (Summit Research Services, USA).

Rat. Male Sprague-Dawley rats $(n=3)$ were dosed with $\mathbf{1}, \mathbf{3 0}, \mathbf{3 1}$, 33 , and 39 either intravenously at a target dose of $1 \mathrm{mg} / \mathrm{kg}$ or orally at a target dose of 10,100 , and $300 \mathrm{mg} / \mathrm{kg}$.

Following discrete intravenous tail vein dosing from a solution of $5 \%$ DMSO:20\% Encapsin in saline, serial blood samples $(\sim 200 \mu \mathrm{L})$ were taken via lateral tail vein at $0.08,0.25,0.5,1,2,4,8$, and $24 \mathrm{~h}$ post dose and placed into individual tubes containing potassium EDTA and thoroughly mixed. Blood samples were placed on ice immediately after collection. Within $2 \mathrm{~h}$ of collection, $70 \mu \mathrm{L}$ of blood sample was transferred to a tube containing $130 \mu \mathrm{L}$ of $0.1 \mathrm{~N}$ Hepes buffer. Following dilution, samples were stored at approximately $-20^{\circ} \mathrm{C}$ or below until analysis.

Following discrete oral gavage dosing from a suspension of $1 \%$ methyl cellulose at target doses of 10,100 , and $300 \mathrm{mg} / \mathrm{kg}$, respectively, serial blood samples $(\sim 200 \mu \mathrm{L})$ were taken via lateral tail vein at 0.25 , $0.5,0.75,1,2,4,6,8$, and $24 \mathrm{~h}$ post dose and placed into individual tubes containing potassium EDTA and thoroughly mixed. Blood samples were placed on ice immediately after collection. Within $2 \mathrm{~h}$ of collection, $70 \mu \mathrm{L}$ of blood sample was transferred to a tube containing 
$130 \mu \mathrm{L}$ of $0.1 \mathrm{~N}$ Hepes buffer. Following dilution, samples were stored at approximately $-20{ }^{\circ} \mathrm{C}$ or below until analysis.

Samples were analyzed for parent using a method based on protein precipitation followed by LCMS/MS with a quantitative range between 2.90 and $2860 \mathrm{ng} / \mathrm{mL}$.

Once analyzed, if concentrations were above the dynamic range of the standard curve, prediluted samples were diluted with blank matrix (1:2.86 whole blood:0.1N Hepes buffer) and processed normally for analysis.

Data Analysis. Data analysis and calculation of pharmacokinetic parameters was performed using Phoenix, WinNonLin version 6.3.

Following the intravenous administration, the whole blood clearance (Cl) was calculated by determining the dose administered to each animal and dividing by the $\mathrm{AUC}_{0-\infty}$. The estimate of the volume of distribution at steady state $\left(V_{\mathrm{ss}}\right)$ was calculated as MRT $\times \mathrm{Cl}$, where MRT is the mean residence time, calculated by $\mathrm{AUMC}_{0-\infty} / \mathrm{AUC}_{0-\infty}$

For both intravenous and oral administration, the systemic exposures were determined by calculating the area under the blood concentration-time curve (AUC) from the start of dosing to the last observed quantifiable concentration $\left(\mathrm{AUC}_{0-\mathrm{t}}\right)$ by using the linear up-log down trapezoidal rule. The slope of the terminal elimination phase was estimated by linear regression of the terminal data points (minimum 3 points) from a natural log concentration vs time plot of the data. The half-life $\left(t_{1 / 2}\right)$ of the terminal elimination phase was calculated as $t_{1 / 2}=$ $0.693 / \mathrm{k}$ (where $k$ is the elimination rate constant).

Graphs were generated using Microsoft Excel.

In Vivo Efficacy Studies. Groups of female BALB/c mice ( 5 per group) were inoculated intravenously with approximately $2 \times 10^{7} \mathrm{~L}$. donovani amastigotes (LV9; WHO designation: MHOM/ET/67/ HU3) harvested from the spleen of an infected hamster. ${ }^{46}$ From day 7 postinfection, groups of mice were treated with either drug vehicle only (orally), with pentostam ( $15 \mathrm{mg} / \mathrm{kg}$ subcutaneously) with miltefosine (12 or $30 \mathrm{mg} / \mathrm{kg}$ orally), with compound 15 (50 mg/kg orally), with compound $30(10,25,50$, and $100 \mathrm{mg} / \mathrm{kg}$ orally), with compound 37 $(25 \mathrm{mg} / \mathrm{kg}$ orally), or with compounds 1,31 , and 39 (10 and $25 \mathrm{mg} / \mathrm{kg}$ orally). Miltefosine was dosed once daily for 5 or 10 days, compound 15 was dosed twice daily for 5 days, compound $\mathbf{3 0}$ was dosed twice daily for 5 and 10 days, and compounds 1, 31, 37, and 39 were dosed twice daily for 10 days. Drug dosing solutions were prepared fresh each day and the vehicle was deionized water for miltefosine and pentostam, $10 \%(\mathrm{v} / \mathrm{v})$ dimethyl sulfoxide (DMSO), $60 \%$ polyethylene glycol 400 , and $30 \%$ deionized water for 15 and 0.5\% HPMC, $0.4 \%$ Tween 80 , and $0.5 \%$ benzyl alcohol for 1, 31, 37, and 39. On day 14 (5 days dosing groups) or 19 ( 10 days dosing groups) all animals were humanely euthanized, liver smears made, and parasite burdens determined by counting the number of amastigotes/500 liver cells. Parasite burden is expressed in Leishman-Donovan units (LDU): the number of amastigotes per 500 nucleated cells multiplied by the organ weight in grammes. ${ }^{30}$

Preclinical Safety Studies. Cytochrome P450 Enzyme Isoform $3 A 4$. CYP3A4 inhibition and metabolism dependent inhibition (MDI) was assessed using a marker substrate (midazolam), monitoring production of CYP3A4 specific metabolite in the presence and absence of test compound at eight concentrations up to $100 \mu \mathrm{M}(0.1$ to $100 \mu \mathrm{M}$, final organic content $\leq 0.5 \%)$. Known inhibitors of CYP3A4 were included as positive control (troleandomycin, ketoconazole, and erythromycin). Data quoted as $\mathrm{IC}_{50}$ and fold shift in $\mathrm{IC}_{50}$ (MDI).

Incubation mixture containing pooled human liver microsomes (final concentration $0.1 \mathrm{mg} / \mathrm{mL}$ ), and either substrate, standard inhibitor, or test compound was preincubated at $37^{\circ} \mathrm{C}$ for $20 \mathrm{~min}$. Either substrate or cofactor was then added and incubated in plate shaker for another $5 \mathrm{~min}$ at $37^{\circ} \mathrm{C}$. Ice-cold acetonitrile 2:1 (v/v) was added to terminate reaction. Depletion of substrates was measured by LC-MS/MS, and $\mathrm{pIC}_{50}$ was measured. If a greater than 1.5-fold change in $\mathrm{pIC}_{50}$ was observed upon preincubation with cofactor values compared to preincubation with substrate values, this suggests that the test compound is a metabolism dependent inhibitor.

Chemoproteomic Profiling on Kinobeads. This assay was conducted as previously described. ${ }^{17}$

Ames. The standard protocol was used for this assay. ${ }^{38}$
Mouse Lymphoma Assay (MLA). The standard protocol was used for this assay. ${ }^{41}$

Human Ether-a-go-go Related Gene (hERG). The standard protocol was used for this assay. ${ }^{39,40}$

Rat 7-Day Toxicology. Test compounds were administered to male $\mathrm{Crl}: \mathrm{WI}(\mathrm{Han})$ rats in a 7 day, oral gavage, repeat-dose study at doses of 100,300 , and $1000 \mathrm{mg} / \mathrm{kg} /$ day.

Rat Cardiovascular Study. Conscious unrestrained telemetered male rats (CRL:WI (Han) were given a single oral dose of either vehicle or test article (up to $1000 \mathrm{mg} / \mathrm{kg}$ ) cardiovascular and electrocardiographic parameters, and body temperature were monitored for $2 \mathrm{~h}$ prior to and for $24 \mathrm{~h}$ after dose.

Ethical Statements. Mouse and Rat Pharmacokinetics. All animal studies were ethically reviewed and carried out in accordance with Animals (Scientific Procedures) Act 1986 and the GSK/Dundee University Policy on the Care, Welfare, and Treatment of Animals

In Vivo Efficacy. All regulated procedures, at the University of Dundee, on living animals was carried out under the authority of a project license issued by the Home Office under the Animals (Scientific Procedures) Act 1986, as amended in 2012 (and in compliance with EU Directive EU/2010/63). License applications will have been approved by the University's Ethical Review Committee (ERC) before submission to the Home Office. The ERC has a general remit to develop and oversee policy on all aspects of the use of animals on University premises and is a subcommittee of the University Court, its highest governing body.

Rat Toxicology Studies. All animal studies were ethically reviewed and carried out in accordance with Animals (Scientific Procedures) Act 1986 and the GSK Policy on the Care, Welfare, and Treatment of Animals

Human Biological Samples. All were sourced ethically and their research use was in accord with the terms of the informed consents.

\section{ASSOCIATED CONTENT}

\section{Supporting Information}

The Supporting Information is available free of charge on the ACS Publications website at DOI: 10.1021/acs.jmedchem. 8 b01218.

Chemistry experimental; crystallography; supplementary data table; synthetic details for all compounds (PDF) Experimental set up and supplementary tables (XLS) Molecular formula strings (CSV)

\section{AUTHOR INFORMATION}

\section{Corresponding Authors}

*For T.J.M.: phone, +34 650 349771; E-mail, tim.j.miles@gsk. com.

*For K.D.R.: phone, +44 1382388 688; E-mail, k.read@dundee. ac.uk.

*For P.G.W.: phone, +44 1382386 231; E-mail, p.g.wyatt@ dundee.ac.uk.

ORCID ${ }^{\circ}$

Manu De Rycker: 0000-0002-3171-3519

Ian H. Gilbert: 0000-0002-5238-1314

Paul G. Wyatt: 0000-0002-0397-245X

Kevin D. Read: 0000-0002-8536-0130

Timothy J. Miles: 0000-0001-7407-7404

\section{Notes}

The authors declare the following competing financial interest(s): The following authors have shares in GlaxoSmithKline: M.Bo., R.C.B.C., S.D.C., A.D., G.D., S.F., S.G.-D., S.G., A.P.H., S.J.H., R.L., F.M., V.L.N., I.H.R., T.U., D.G., J.M.F., P.G.W., K.D.R., and T.J.M. The other authors declare no competing interests. 


\section{ACKNOWLEDGMENTS}

Funding for this work was provided by the Wellcome (nos. 092340 and 100476). We thank Gina MacKay and Daniel Fletcher for performing HRMS analyses and for assistance with performing other NMR and MS analyses, Irene Hallyburton for performing the axenic assay, Raul Fernandez Velasco and the rest of the Galchimia chemistry team plus Colin P. Leslie and the rest of the Aptuit chemistry team for synthesizing key compounds, Professor W. Clegg and Dr. R. W. Harrington plus Dr. M. R. Probert for the GSK-funded crystal structures of 1 and 15, Alastair Pate and Francesco Gastaldello for data management, and finally Dr. Robert J. Young for critical evaluation of the manuscript.

\section{ABBREVIATIONS USED}

THP-1, human monocytic cell line derived from an acute monocytic leukemia patient; HPMC, hydroxypropyl methylcellulose; VL, visceral leishmaniasis; CRK-12, cdc2-related kinase 12

\section{REFERENCES}

(1) World Health Organization (WHO) List of Neglected Tropical Diseases; World Health Organization: Geneva, 2018; http://www.who. int/neglected diseases/diseases/en/ (accessed Aug 2, 2018).

(2) Field, M. C.; Horn, D.; Fairlamb, A. H.; Ferguson, M. A. J.; Gray, D. W.; Read, K. D.; De Rycker, M.; Torrie, L. S.; Wyatt, P. G.; Wyllie, S.; Gilbert, I. H. Anti-trypanosomatid drug discovery: an ongoing challenge and a continuing need. Nat. Rev. Microbiol. 2017, 15 (4), 217-231.

(3) World Health Organization (WHO) Leishmaniasis Fact Sheet; World Health Organization: Geneva, 2018; http://www.who.int/ mediacentre/factsheets/fs375/en/ (accessed Aug 2, 2018).

(4) Moore, E. M.; Lockwood, D. N. Treatment of visceral leishmaniasis. J. Glob. Infect. Dis. 2010, 2 (2), 151-158.

(5) Sundar, S.; Singh, A.; Rai, M.; Prajapati, V. K.; Singh, A. K.; Ostyn, B.; Boelaert, M.; Dujardin, J.-C.; Chakravarty, J. Efficacy of Miltefosine in the Treatment of Visceral Leishmaniasis in India After a Decade of Use. Clin. Infect. Dis. 2012, 55 (4), 543-550.

(6) den Boer, M. L.; Alvar, J.; Davidson, R. N.; Ritmeijer, K.; Balasegaram, M. Developments in the treatment of visceral leishmaniasis. Expert Opin. Emerging Drugs 2009, 14 (3), 395-410.

(7) Mueller, M.; Ritmeijer, K.; Balasegaram, M.; Koummuki, Y.; Santana, M. R.; Davidson, R. Unresponsiveness to AmBisome in some sudanese patients with kala-azar. Trans. R. Soc. Trop. Med. Hyg. 2007, 101 (1), 19-24.

(8) Drugs for Neglected Diseases initative (DNDi) Portfolio; Drugs for Neglected Diseases initative (DNDi), June 2018; https://www.dndi. org/diseases-projects/portfolio/ (accessed Oct 5, 2016).

(9) Drugs for Neglected Diseases initative (DNDi) Target Product Profile for Visceral Leishmaniasis; Drugs for Neglected Diseases initative (DNDi), 2016; https://www.dndi.org/diseases-projects/ leishmaniasis/tpp-vl/ (accessed Oct 5, 2016).

(10) Freitas-Junior, L. H.; Chatelain, E.; Kim, H. A.; Siqueira-Neto, J. L. Visceral leishmaniasis treatment: what do we have, what do we need and how to deliver it? Int. J. Parasitol.: Drugs Drug Resist. 2012, 2, 1119.

(11) Gilbert, I. H. Drug discovery for neglected diseases: molecular target-based and phenotypic approaches. J. Med. Chem. 2013, 56 (20), $7719-7726$.

(12) Palmer, M. J.; Wells, T. N. C.; Eds., Neglected Diseases and Drug Discovery. [In: RSC Drug Discovery Ser., 2012; 14; 438]. Royal Society of Chemistry: 2012; p 134-202.

(13) Harhay, M. O.; Olliaro, P. L.; Costa, D. L.; Costa, C. H. N. Urban parasitology: visceral leishmaniasis in Brazil. Trends Parasitol. 2011, 27 (9), 403-409.
(14) De Rycker, M.; Hallyburton, I.; Thomas, J.; Campbell, L.; Wyllie, S.; Joshi, D.; Cameron, S.; Gilbert, I. H.; Wyatt, P. G.; Frearson, J. A.; Fairlamb, A. H.; Gray, D. W. Comparison of a high-throughput highcontent intracellular leishmania donovani assay with an axenic amastigote assay. Antimicrob. Agents Chemother. 2013, 57 (7), 29132922.

(15) Don, R.; Ioset, J.-R. Screening strategies to identify new chemical diversity for drug development to treat kinetoplastid infections. Parasitology 2014, 141 (1), 140-146.

(16) Miles, T. J.; Thomas, M. G. Pyrazolo[3,4-d]pyrimidin Derivative and its use for the Treatment of Leishmaniasis. WO Patent WO2016116563A1, 2016

(17) Wyllie, S.; Thomas, M.; Patterson, S.; Crouch, S.; De Rycker, M.; Lowe, R.; Gresham, S.; Urbaniak, M. D.; Otto, T. D.; Stojanovski, L.; Simeons, F. R. C.; Manthri, S.; MacLean, L. M.; Zuccotto, F.; Homeyer, N.; Pflaumer, H.; Boesche, M.; Sastry, L.; Connolly, P.; Albrecht, S.; Berriman, M.; Drewes, G.; Gray, D. W.; Ghidelli-Disse, S.; Dixon, S.; Fiandor, J. M.; Wyatt, P. G.; Ferguson, M. A. J.; Fairlamb, A. H.; Miles, T. J.; Read, K. D.; Gilbert, I. H. Cyclin-dependent kinase 12 is a drug target for visceral leishmaniasis. Nature 2018, 560 (7717), 192-197.

(18) Woodland, A.; Grimaldi, R.; Luksch, T.; Cleghorn, L. A. T.; Ojo, K. K.; Van Voorhis, W. C.; Brenk, R.; Frearson, J. A.; Gilbert, I. H.; Wyatt, P. G. From on-target to off-target activity: identification and optimization of trypanosoma brucei GSK3 Inhibitors and their characterisation as anti-trypanosoma brucei drug discovery lead molecules. ChemMedChem 2013, 8 (7), 1127-1137.

(19) Ding, Q.; Jiang, N.; Roberts, J. L. Preparation of Pyrazolopyrimidines as Antitumor Agents. US Patent US20050277655A1, 2005.

(20) Merritt, C.; Silva, L. E.; Tanner, A. L.; Stuart, K.; Pollastri, M. P. Kinases as druggable targets in trypanosomatid protozoan parasites. Chem. Rev. 2014, 114 (22), 11280-11304.

(21) Dichiara, M.; Marrazzo, A.; Prezzavento, O.; Collina, S.; Rescifina, A.; Amata, E. Repurposing of human kinase Inhibitors in neglected protozoan diseases. ChemMedChem 2017, 12 (16), 12351253.

(22) Ferguson, F. M.; Gray, N. S. Kinase inhibitors: the road ahead. Nat. Rev. Drug Discovery 2018, 17 (5), 353-377.

(23) Hill, A. P.; Young, R. J. Getting physical in drug discovery: a contemporary perspective on solubility and hydrophobicity. Drug Discovery Today 2010, 15 (15-16), 648-655.

(24) Gupta, S.; Nishi. Visceral leishmaniasis: experimental models for drug discovery. Indian J. Med. Res. 2011, 133, 27-39.

(25) Seifert, K.; Croft, S. L. In vitro and in vivo interactions between miltefosine and other antileishmanial drugs. Antimicrob. Agents Chemother. 2006, 50 (1), 73-79.

(26) Escobar, P.; Yardley, V.; Croft, S. L. Activities of hexadecylphosphocholine (miltefosine), AmBisome, and sodium stibogluconate (Pentostam) against leishmania donovani in immunodeficient scid mice. Antimicrob. Agents Chemother. 2001, 45 (6), 1872-1875.

(27) Dorlo, T. P. C.; Huitema, A. D. R.; Beijnen, J. H.; de Vries, P. J. Optimal dosing of miltefosine in children and adults with visceral leishmaniasis. Antimicrob. Agents Chemother. 2012, 56 (7), 3864-3872.

(28) Dorlo, T. P. C.; Rijal, S.; Ostyn, B.; de Vries, P. J.; Singh, R.; Bhattarai, N.; Uranw, S.; Dujardin, J.-C.; Boelaert, M.; Beijnen, J. H.; Huitema, A. D. R. Failure of miltefosine in visceral leishmaniasis is associated with low drug exposure. J. Infect. Dis. 2014, 210 (1), 146153.

(29) Wyllie, S.; Patterson, S.; Stojanovski, L.; Simeons, F. R.; Norval, S.; Kime, R.; Read, K. D.; Fairlamb, A. H. The anti-trypanosome drug fexinidazole shows potential for treating visceral leishmaniasis. Sci. Transl. Med. 2012, 4 (119), 119re1.

(30) Bradley, D. J.; Kirkley, J. Regulation of leishmania populations within the host. I. the variable course of leishmania donovani infections in mice. Clin. Exp. Immunol. 1977, 30 (1), 119-129.

(31) Young, R. J.; Green, D. V. S.; Luscombe, C. N.; Hill, A. P. Getting physical in drug discovery II: the impact of chromatographic hydrophobicity measurements and aromaticity. Drug Discovery Today 2011, 16 (17-18), 822-830. 
(32) Klein, S. The use of biorelevant dissolution media to forecast the in vivo performance of a drug. AAPS J. 2010, 12 (3), 397-406.

(33) Gilbert, I. H.; Thomas, M. G. Preparation of Antileishmanial Pyrazolopyrimidines. WO Patent WO2016116752A1, 2016.

(34) Di, L.; Fish, P. V.; Mano, T. Bridging solubility between drug discovery and development. Drug Discovery Today 2012, 17 (9-10), 486-495.

(35) The Sirius Gold Standard pKa Assays; Pion, 2018; http://www. sirius-analytical.com/analytical-services/gold-standard-assays (accessed Aug 2, 2018).

(36) Jain, N.; Yalkowsky, S. H. Estimation of the aqueous solubility I: application to organic nonelectrolytes. J. Pharm. Sci. 2001, 90 (2), 234252.

(37) Young, R. J. Physical properties in drug design. Topics in Medicinal Chemistry; Tactics in Contemporary Drug Design, Springer: Berlin, Heidelberg, 2014; Vol. 9, pp 1-68, DOI: 10.1007/ 7355_2013_35.

(38) Ames, B. N.; McCann, J.; Yamasaki, E. Methods for detecting carcinogens and mutagens with the salmonella/mammalian-microsome mutagenicity test. Mutat. Res. 1975, 31 (6), 347-364.

(39) Tao, H.; Santa Ana, D.; Guia, A.; Huang, M.; Ligutti, J.; Walker, G.; Sithiphong, K.; Chan, F.; Guoliang, T.; Zozulya, Z.; Saya, S.; Phimmachack, R.; Sie, C.; Yuan, J.; Wu, L.; Xu, J.; Ghetti, A. Automated tight seal electrophysiology for assessing the potential hERG liability of pharmaceutical compounds. Assay Drug Dev. Technol. 2004, 2 (5), 497-506.

(40) Ly, J. Q.; Shyy, G.; Misner, D. L. Assessing hERG channel inhibition using PatchXpress. JALA 2005, 10 (4), 225-230.

(41) Clive, D.; Johnson, K. O.; Spector, J. F.; Batson, A. G.; Brown, M. $\mathrm{M}$. Validation and characterization of the L5178Y/TK \pm mouse lymphoma mutagen assay system. Mutat. Res., Fundam. Mol. Mech. Mutagen. 1979, 59 (1), 61-108.

(42) Liu, T.; Brown, B. S.; Wu, Y.; Antzelevitch, C.; Kowey, P. R.; Yan, G.-X. Blinded validation of the isolated arterially perfused rabbit ventricular wedge in preclinical assessment of drug-induced proarrhythmias. Heart Rhythm 2006, 3 (8), 948-956.

(43) Shah, R. R. Drug-induced QT interval shortening: potential harbinger of proarrhythmia and regulatory perspectives. Br. J. Pharmacol. 2010, 159 (1), 58-69.

(44) Alvar, J.; Velez, I. D.; Bern, C.; Herrero, M.; Desjeux, P.; Cano, J.; Jannin, J.; den Boer, M. Leishmaniasis worldwide and global estimates of its incidence. PLoS One 2012, 7 (5), No. e35671.

(45) Valko, K.; Bevan, C.; Reynolds, D. Chromatographic hydrophobicity index by fast-gradient RP-HPLC: a high-throughput alternative to $\log \mathrm{P} / \log \mathrm{D}$. Anal. Chem. 1997, 69 (11), 2022-2029.

(46) Wyllie, S.; Fairlamb, A. H. Refinement of techniques for the propagation of leishmania donovani in hamsters. Acta Trop. 2006, 97 (3), 364-369.

(47) Sacks, D.; Sher, A. Evasion of innate immunity by parasitic protozoa. Nat. Immunol. 2002, 3 (11), 1041-1047. 